
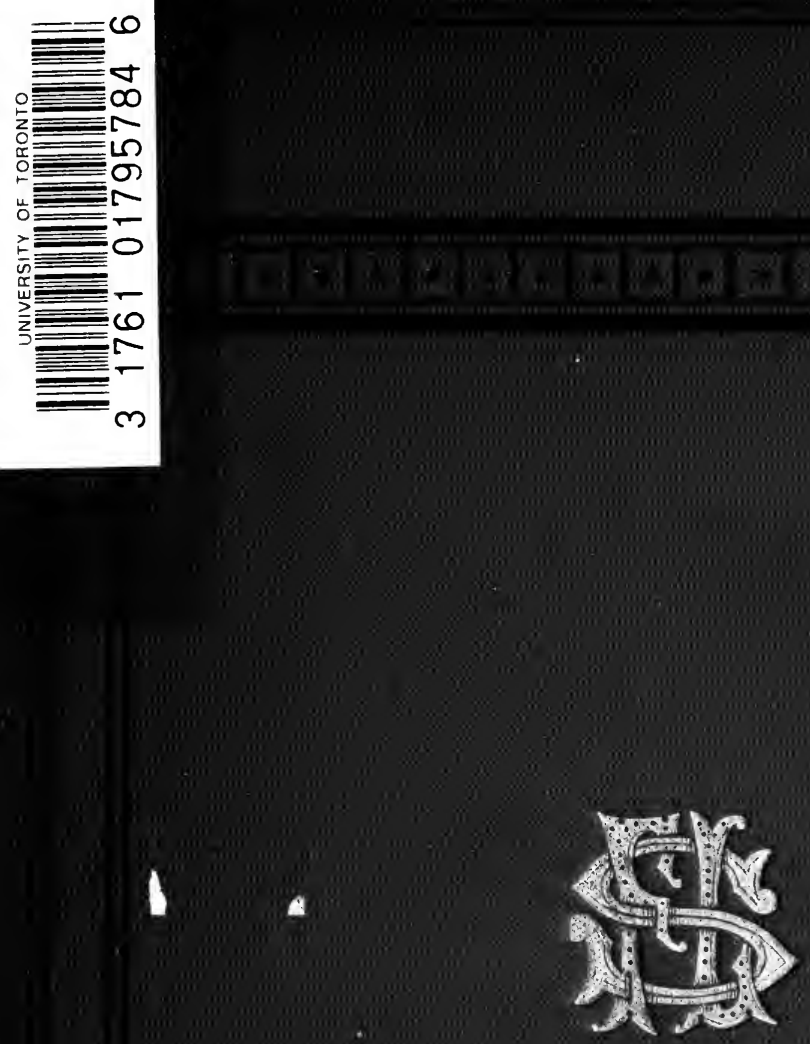



\section{,}


G2w. Tlacbean 


\title{
The Folk-Lore Society. (1899.)
}

\author{
Bresident. \\ E. S. HARTLAND, F.S.A.
}

Vice=fresioents.

THE HON. JOHN ABERCROMBY.

MISS C. S. BURNE.

EDWARD CLODD.

G. LAURENCE GOMME, F.S.A.

ANDREW LANG, M.A., I.L.D.

THE RIGHT HON. SIR JOHN LUBBOCK, BART., M.P., D.C.L,

LL.D., F.R.S., F.S.A., F.G.S., F.L.S.

ALFRED NU'TT.

LT.-GEN. PITT-RIVERS, D.C.L., F.R.S., F.S.A., F.G.S., F.R.G.S.

PROFESSOR F. YORK POIVELL, M.A., F.S.A.

PROFESSOR J. RHYS, M.A., LL.D., F.S.A.

THE REV. PROFESSOR A. HI. SAYCE, M.A., LL.D., D.D.

PROFESSOR EDWARD B. TYLOR, LL.D., D.C.L., F.R.S.

C. J. BILLSON, M.A.

DR. KARL BLIND.

H. C. BOWEN, M.A.

F. C. CONYBEARE, M.A.

J. E. CROMBIE.

W. CROOKE, B.A.

LELAND L. DUNCAN, F.S.A.

J. P. EMSLIE.

T. GOWLAND.

MISS F. GROVE.

Council.

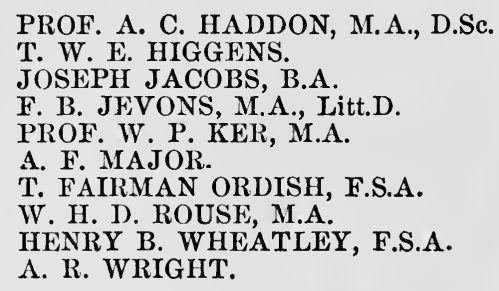

Zgon. Treasurer.

E. W. BRABROOK, C.B., F.S.A., 178, Bedford Hill, Balham, S.W.

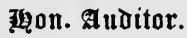

F. G. GREEN.

\section{Eecretary.}

F. A. MILNE, M.A., 11, Old Square, Iincoln's Inn, London, W.C.

\section{Etanding Cemmitters:}

PUBLICATIONS COMMITTEE.

THE PRESIDENT (Chairman); G. L. GOMME (Vice-Chairman); E. K. CHAMBERS ; MISS M. ROALEE COX; W. CROOKE; PROFESSOR W. P. KER ; A. NUTT.

BIBLIOGRAPHY COMMITTEE.

G. L. GOMME (Chairman) ; L. L. DUNCAN ; J. JACOBS ; W. F. KIRBY ; J. T. NAAKÉ.

MUSEUM COMMITTEE.

G. L. GOMME (Chairman); J. P. EMSLIE; ARTHUR J. EVANS ; T. GOWLAND ; MISS M. C. FFENNELL; A. R. WRIGHT. The President and Treasurer are ex-ufficio members of all Committees. 
CATALOGUE OF A COLLECTION OF OBJECTS

\section{ILLUSTRATING THE FOLKLORE OF MEXICO.}


Digitized by the Internet Archive in 2007 with funding from Microsoft Corporation. 


\section{CATALOGUE}

OF

\section{A COLLECTION OF OBJECTS}

ILLUSTRATING THE

\section{FOLKLORE OF MEXICO.}

BY

\section{FREDERICK STARR,}

PROFESSOR OF ANTHROPOLOGY IN THE UNIVERSITY OF CHICAGO.

WITH THIR'TY-TWO FIGURES.

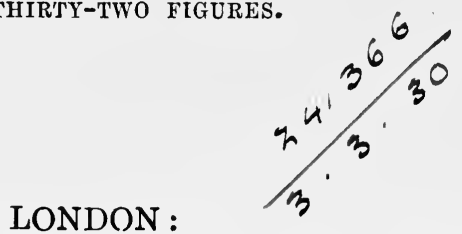

PUBLISHED FOR THE FOLK-LORE SOCIETY B Y DAVID N UTT, $270-27$ I, STRAND.

1899. 


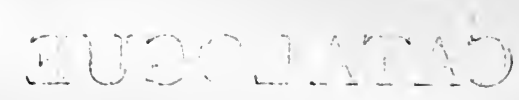<smiles>C#CC#CC</smiles> 


\section{INTRODUCTION.}

THE Collection of Objects described in the following pages is a gift by Professor Starr to the Folk-Lore Society. It is due to him, as well as of interest to the Members of the Society, to state shortly how it was this gift came to be made, and upon what conditions. Being at Chicago in the latter days of August, 1897, I took the opportunity of calling on Professor Starr, with whom I had already had some correspondence on anthropological matters, and whose personal acquaintance I was anxious to make. He received me with great kindness; and in the course of the interview I learned that he was making, a special study of the anthropology of Mexico; and he showed me many interesting things which he had brought back from his travels in that country. I was especially attracted by a series of pottery figures (Tastoanes) representing the characters in a passion play performed in one of the country districts of Mexico, and a series of masks, also in pottery, worn by the actors. As I listened there came upon me the wish to secure a set of the figures for the FolkLore Society; and I inquired whether it would not be possible to do so. Professor Starr readily and kindly undertook to procure a set for me. After my return home, however, I received a letter from him, intimating that he had changed his mind, and offering instead to make at his own expense, and present to the Society, a Collection of Objects illustrating the Folklore of Mexico, subject to three conditions:-

1. That the Collection should be kept as a Mexican Collection, with the donor's name attached. 
2. That the Society should print an Illustrated Catalogue which he would prepare and pass through the press.

3. That the objects should be displayed at a meeting of the Society, which he would attend, and when he would describe and explain some of the more important items.

This letter I forwarded without loss of time to Mr. Alfred Nutt, then President of the Society, who took the matter up warmly. A Council Meeting was called, and Professor Starr's generous offer was gratefully accepted. The Collection arrived in London last winter; and in June the donor himself came over and unpacked the boxes. A joint meeting of the Folk-Lore Society and of the Anthropological Institute was held, by the kindness of the Institute, at its rooms, on the 27th June, at which Professor Starr exhibited and explained the Collection.

It would be out of place to attempt here a formal appreciation of either the Collection or the Catalogue. Their value will be obvious on the most cursory glance at the pages which follow. As a sample, however, of the minuteness of Professor Starr's ethnological observations, I would draw attention to the section on Children's Outdoor Games, occupying upwards of 33 pages of the Catalogue-a section of course unrepresented by anything in the Collection. The scientific interest and importance of Children's Games have hardly as yet been adequately recognised. But anthropologists who, like Professor Starr, have had the opportunity of studying the games of savage children on the spot, are awake to the lessons that may be learnt from them. The account of the games of Mexican-Spanish children given here may be compared with those of British and American children's games by Mrs. Gomme and Mr. Newell, and with that of Sicilian children's games by Dr. Pitrè in the thirteenth volume of his great Biblioteca 
delle Tradizioni Popolari Siciliane. Dr. Feilberg's study of the game of Hopscotch as played in Denmark (Folklore, vol. vi., p. 359) will also form an admirable commentary on the analogous games reported and illustrated by diagrams in this volume.

The formal thanks of the Folk-Lore Society have already been tendered to Professor Starr. But the Society desires further to place on record here its keen sense of gratitude for his generosity, and to express the hope that the Collection in its permanent place of deposit (the University Museum of Archæology and Ethnology, Cambridge) and this Catalogue may realise the intentions of the donor, by the facilities they will afford, especially to British and American students of anthropology, for studying the traditions of the MexicanSpanish population of the ancient empire of the Aztecs.

E. SIDNEY HARTLAND.

Highgarth, Gloucester, October, 1899. 



\section{PREFACE.}

THIs little book is simply a descriptive and illustrated catalogue of a collection of objects-not a treatise on Mexican Folklore. Once only has the writer gone beyond his field the subject of Children's Games is more fully treated than necessary. ' In securing children's toys on the one hand and board games on the other, considerable material was gathered regarding outdoor and indoor games, which it seemed a pity not to preserve. Hence it has been printed here, although admittedly incomplete.

The collection here described is not a collection of ethnographic objects: the pure-blood Indians, who form the population of Southern Mexico, are not represented in it. Objects illustrating their life and customs are hardly folklore objects. The six hundred and thirty or more objects here gathered together represent the Mestizos, or mixed bloods of Northern and Central Mexico. Their blood is a mixture of Spanish and Indian: their life is a mixture of that of South Europe in the fifteenth and of America at the end of the nineteenth centuries: their religion is a mixture of native paganism and imported Christianity. Nowhere is there a more interesting field for the folklorist. Here are dialect developments; here are proverbs, witty and wise; here are folksongs, sweet and touching; here are folk-tales untouched by skepticism; here are charms and formulae; here are 
witches and fairies in the full height of their power; here are popular street celebrations and dramas; here are a hundred Oberammergaus with passion-plays and miracle-plays unspoiled by the crowds of visitors; here are a thousand strange survivals of pagan barbarism in the midst of Christian civilization.

One error, often made, must be avoided. Mexico is frequently thought of as backward and barbaric. Mexico has a common "folk" and much "folklore" We deal with the lore of the common Mestizo folk. But, on one side of it is the Indian, and on the other side of it is the enlightened and progressive Mexican, who has made Mexico what it is to-day - a great and prosperous, progressive and rapidly advancing nation. The men who make Mexico to-day are the peers of any in our own lands. They are men of thought and action. Modern Mexico has its poets and prose writers, its historians and dramatists, its artists and musicians, its financiers and statesmen. Men like Icazbalceta and Orozco y Berra, Roa Barcena and Altamirano, Limantour and Diaz, and the mighty Juarez do not lose by comparison with the great of other lands. I should be sorry if either Collection or Catalogue gave a false impression regarding this most deserving land and people.

Much here described is perhaps only Catholic, and might equally well have come from any Catholic land. Still even this has probably received a local impress or retains an ancient quaintness. We have made no effort to sift or sort. Here is the material, if others care to analyze and compare.

To all the many who have aided us in securing objects and data we give thanks. Especial thanks, however, are due to David A. Wilson of Guadalajara, William D. Powell of Toluca, Miss Butler of the City of Mexico, and Miss McCormick and Miss Harriman of Morelia.

FREDERICK STARR. 


\section{TABLE OF CONTENTS.}

PAGE

LOCAL INDUSTRIes

Shop Signs and Names...

Street Cries

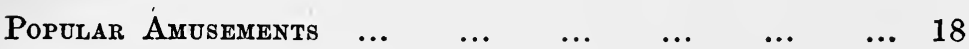

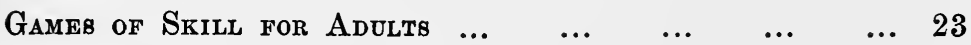

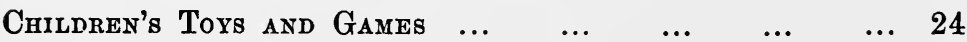

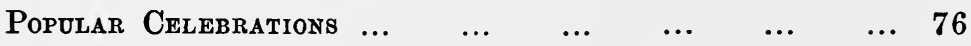

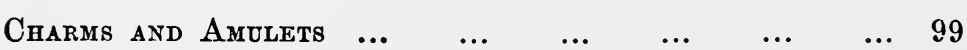

$\begin{array}{llllllllll}\text { WitchCRAFt } & \ldots & \ldots & \ldots & \ldots & \ldots & \ldots & \ldots & 102\end{array}$

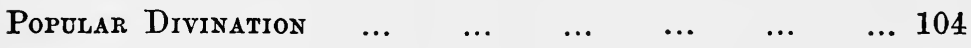

$\begin{array}{llllllll}\text { Popdlar Medicine } & \ldots & \ldots & \ldots & \ldots & \ldots & \ldots & 106\end{array}$

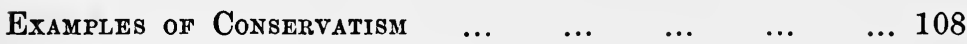

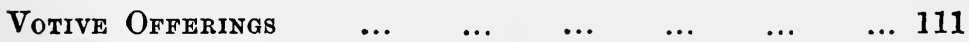

$\begin{array}{lllllllll}\text { Religious Miscellany } & \ldots & \ldots & \ldots & \ldots & \ldots & \ldots & 118\end{array}$

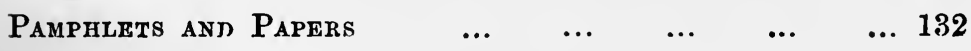





\section{LIST OF ILLUSTRATIONS.}

Fig.

1. Wall Display of Kitchen Pottery : Silao (No. 27)

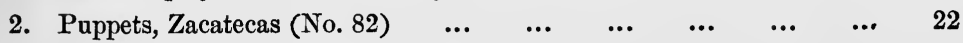

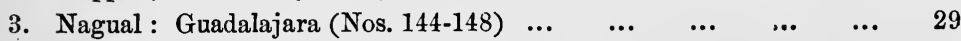

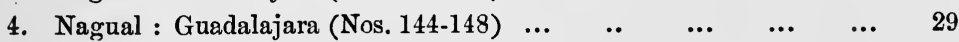

5. Nagual and Muerto : Guadalajara (No. 149) $\ldots \begin{array}{llllll} & \ldots & \ldots & \ldots & \ldots & 30\end{array}$

6. Nagual and Muerto : Guadalajara (No. 149) $\ldots \begin{array}{llllll} & \ldots & \ldots & \ldots & \ldots & 30\end{array}$

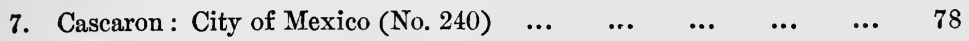

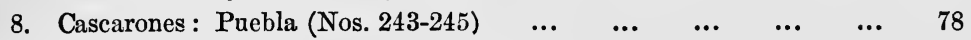

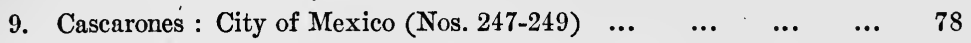

10. Seller of Matracas : City of Mexico (Nos. 256-272) $\quad \ldots \quad \ldots \quad$... $\quad 81$

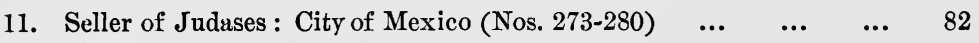

12. Masks of Tastoanes: Guadalajara (Nos. 281-291) $\quad \ldots \quad \ldots . \quad \ldots \quad 83$

13. Masks of Tastoanes : Guadalajara (Nos. 281-291) $\quad \ldots \quad \ldots \quad \quad \ldots \quad 83$

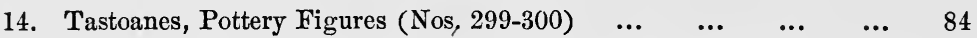

15. Thin Candy Figure sold at the Feast of the Dead : Toluca (No. 308) 86

16. Thin Candies sold at the Time of the Feast of the Dead : Toluca

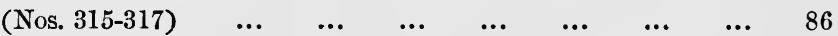

17. Candies sold at the time of the Feast of the Dead: Toluca (Nos. 329, $332,334,336,337,338,339,340,341,343,344,345) \quad \ldots \quad \quad \ldots \quad 87$

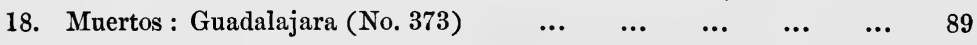

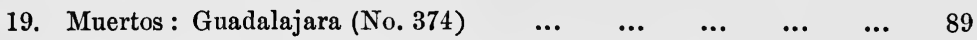

20. Table spread for the Dead : City of Mexico (No. 386) $\quad \ldots \quad \quad \ldots \quad 89$

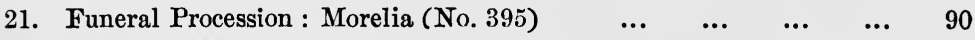

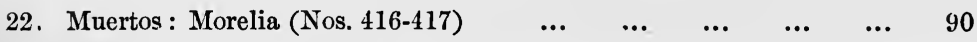

23. Mask of Hermit in the Pastores : Guadalajara (No.421) $\quad \ldots \quad \ldots \quad$.. 91

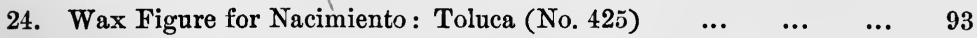

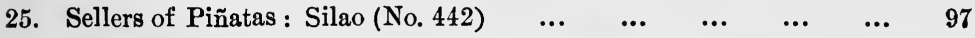

25. Silver Ex-votos, from various localities (Nos. 504-530) $\quad \ldots \quad \ldots \quad 111$

27. Collection of Cilicias and Disciplinas, belonging to Mr. D. A.

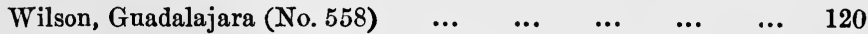

28. Cross to ensure success of Crops : Near Tezontepec (No. 578) $\quad \ldots \quad 123$

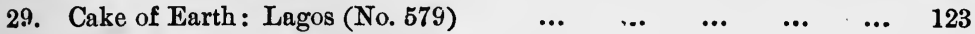

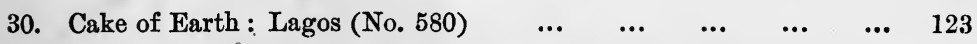

31. Palm blessed on Palm Sunday : Guadalajara (No. 584) $\quad \ldots \quad$... 124

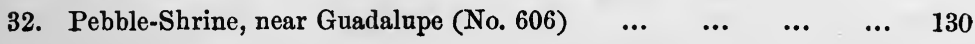





\section{CATALOGUE}

OF

\section{A COLLECTION OF OBJECTS}

ILLUSTRATING

\section{THE FOLKLORE OF MEXICO.}

\section{LOCAL INDUSTRIES.}

IN Mexico local industries and local arts are most strikingly developed. In some districts every town almost has some speciality. Thus, along the line of the Mexican Central Railway, Aguas Calientes is famous for its drawn-work and its horsehair toys; Irapuato is the strawberry station, with fresh berries every day of the year ; Celaya is renowned for its dulces, chiefly condensed milk with almond flavouring; Salamanca is synonymous with gloves. Where an art or industry is widely developed, the product is locally different. Thus, in pottery-the true art of arts in Mexico-at Guadalupe, pressed vessels in black-glazed ware, present the forms of man, fish, and fowl; Cuauhtitlan gives a common, black and brown mottled ware in graceful pitcher and vase forms; Oaxaca has a dark green-glaze ware, in simple but varied forms; at Encarnacion canteens and pitchers of a fine-grained dull-red ware, bear low, stamped, intaglio decoration; San Felipe turns out "lustred ware," \&c. Even in modes of work such local diversity exists. A missionary at Aguas Calientes, building a schoolhouse, had workmen from the 
locality and others from a neighbouring town. The two parties had to be kept at work on different walls, as they did their work in different manners, and each considered the other's method inferior. Water-carriers in different cities have characteristic water-jars, differing in form, size, and mode of carrying. The first specimens in the collection illustrate this local diversity. The evidence of archæology goes to show that analogous notable local differences marked the pre-Conquest Mexican life.

\section{TOYS OF HORSE-HAIR:}

These little objects are made chiefly at Aguas Calientes, though recently (to supply tourist demands) Silao and Irapuato have become centres of manufacture. The hairs are dyed and woven into shapes, the commonest of which are little hats (sombreritos) and small baskets (canastitas) of various patterns.

1. Horse-Hair Toy: sombrerito. Aguas Calientes.

2.

3. " "

$\begin{array}{cc}\text { canastita } & , \\ ,, \quad \text { different } & ,\end{array}$

\section{DRAWN-WORK (Costura) :}

Mexican drawn-work is now well known everywhere quantities being sent yearly to the United States and other countries. It is a domestic industry, the work being done in the little houses of the poor. Women are the workers. The art is taught in some of the public schools as a means of livelihood. Linen, silk, and cotton are the chief materials. An introduced art, it has had a notable development in its new home, and many of the patterns are original to Mexico. The patterns of the centre and the outer band differ, and each has its own name. In the following list the outer pattern is 
first named, then the inner. The names are given in Spanish and then translated.

5. Drawn-Work: El Diablo: las cruces. The devil: the crosses.

6. $\quad$,

7. $\quad$.

8. $\quad$,

9. $\quad$,

10. $"$

11.,

12. $"$

13. "

14. $"$

$15 . \quad \cdots$

16.

Los dominos: njos de San Pedro. The dominos : eyes of St. Peter.

Hállame si puedes : las marias. Find me if you can : the Marias.

Los Jesusitos: los cruzados. The little Jesuses : crossed.

La Piña: ojo de mosco. The pineapple: fly's eye.

Rueda de coche : lomillo con ovaiitos. Cartwheel: hemming with little ovals.

Las margaritas : la lagrima. The pearls : the tear.

Lossoles: ojo de pollo. Suns : chicken's eye. El relindo: costilla de raton. Neat: rat's rib.

Los durasnos: corazon de cidra. The peaches : heart of citron.

Los rejillitas : la semilla de melon. The little lattices: Melon-seed.

Los resplandores: la estrella. Brilliants: the star.

Some of these names are strikingly appropriate. To call the little figure in the border of 8, Jesusito-the little Jesus-is entirely in keeping with the religious bent of the country. The fly's eyes, chicken's eye, teardrop, rat's rib, melon-seed, are all pat and striking. The heart of the citron is accurate: the pattern strikingly resembles the figure presented by a cross cut of a lemon or orange. It is only fair to say, however, that while it is customary to name patterns, many names vary not only with districts but even with individual workers. 
The specimens represent a medium grade of work

\section{SILVER FIGURES :}

The four great silver towns of Mexico are Zacatecas, Guanajuato, Pachuca, and Chihuahua. At Guanajuato, for a long time past, cunning workmen have made little figures of silver. These represent various types, but the commonest are miners. Often miniature landscapes are constructed of bits of spar and ore, representing mining shafts, tunnels, and deposits of " mineral," and the little figures of busy workmen are set in them as if they were at work. The figures made long ago are neater and more artistic than those made to-day, but are rare and bring good prices.

17. Silver figurine: miner. Guanajuato.

18.

\section{IRON WITH INLAID SILVER:}

The beautiful art of inlaying iron with silver is to-day of limited practice in Mexico. Amozoc, in the State of Puebla, is famous for it. The articles commonly made are pieces of harness and smoothing irons. Other articles of many kinds are made to order. Some of the Amozoc work is not true silver inlaying, but cutting of white designs in the blue metal : this etching or engraving resembles the true inlaid work to a careless observer.

19. Buttons with etched designs. Amozoc.

20. Cinch ring with inlaid silver. Amozoc.

\section{LUSTRED POTTERY :}

Among arts introduced by the Spaniards and dating back beyond them to the Saracens is the making of lustred or 
iridescent pottery. The best-known lustred pottery of Mexico is made at San Felipe, in the State of Guanajuato. It is richly lustred, over a very coarse and cheap foundation, in bronzes and metallic greens that change with the angle at which the light falls upon them. Originally the makers manufactured only little vessels in the forms of bowls, cups, and pitchers. Under the demand and direction of dealers in curios they now make larger pieces-bowls, sugar-bowls, plates, pitchers. Native customers rarely buy these but remain loyal to the old types. The makers travel on foot from San Felipe, with great crates of this ware on their backs, to the fairs and markets where they sell. The usual price for such little pieces is about a farthing. Addis described this ware in a paper entitled Mexican Lustred Pottery (Harper's Magazine, Aug., 1869. See No. 620.)

21. Lustred Ware: cup. San Felipe.

\begin{tabular}{|c|c|c|c|c|}
\hline 22. & " & $"$ & bowl-plate. & San Feìpe \\
\hline & " & " & $"$ & $"$ \\
\hline & $"$ & , & $"$ & " \\
\hline & " & ", & vase & , \\
\hline
\end{tabular}

The common Mexican, and especially the common Mexican woman-be she mixed-blood or Indian-is fond of pretty things, and especially fond of pottery. She delights in securing specimens of pretty wares from all parts of the Republic. Her collection is much less for use than for display. She groups her treasures symmetrically and artistically on the kitchen wall. Sometimes scores of pieces from a dozen localities are thus displayed. While these wall displays occur in many places they are especially numerous in the towns and cities of the State of Guanajuato, such as Guanajuato, Leon, and Silao. 
26. Kitchen wall display of pottery (photograph).

27.

28.

all at Silao.

\section{STRAW PICTURES ·}

The making of landscapes and pictures of national types in colored straws is a local and individual art in the hands of a few Indians in Puebla and the City of Mexico. The straws are stained, cut and laid in position to form designs, usually somewhat stiff and awkward, but in the best specimens quite artistic. The specimens sent are of the cheaper and commoner grade.

29. Straw picture: aguador or water-seller. City of Mexico. 30. Straw picture: tlachiquero or agua miel collector. City of Mexico.

The chief intoxicant of Mexico is pulque, the fermented sap of the agave or maguey. The plant grows for about twelve years without flowering. It then produces a central flower-bud at the base of the leaves. This is cut out, leaving a large, carefully-shaped cup. Into this cup the sap pours, and from it, it is collected by means of a long and slender gourd. The smaller end of this is inserted into the cup, and the air is sucked out at the larger end, by the man. The sap or agua miel rises in the gourd and is transferred to the goat-skin* bottle which the tlachiquero carries on his back. The tall straight plants represented in line behind the man are the organo cactus, much used for fences or hedges in Middle and Southern Mexico.

* Not a pigskin, though often so stated by careless traveilers. 


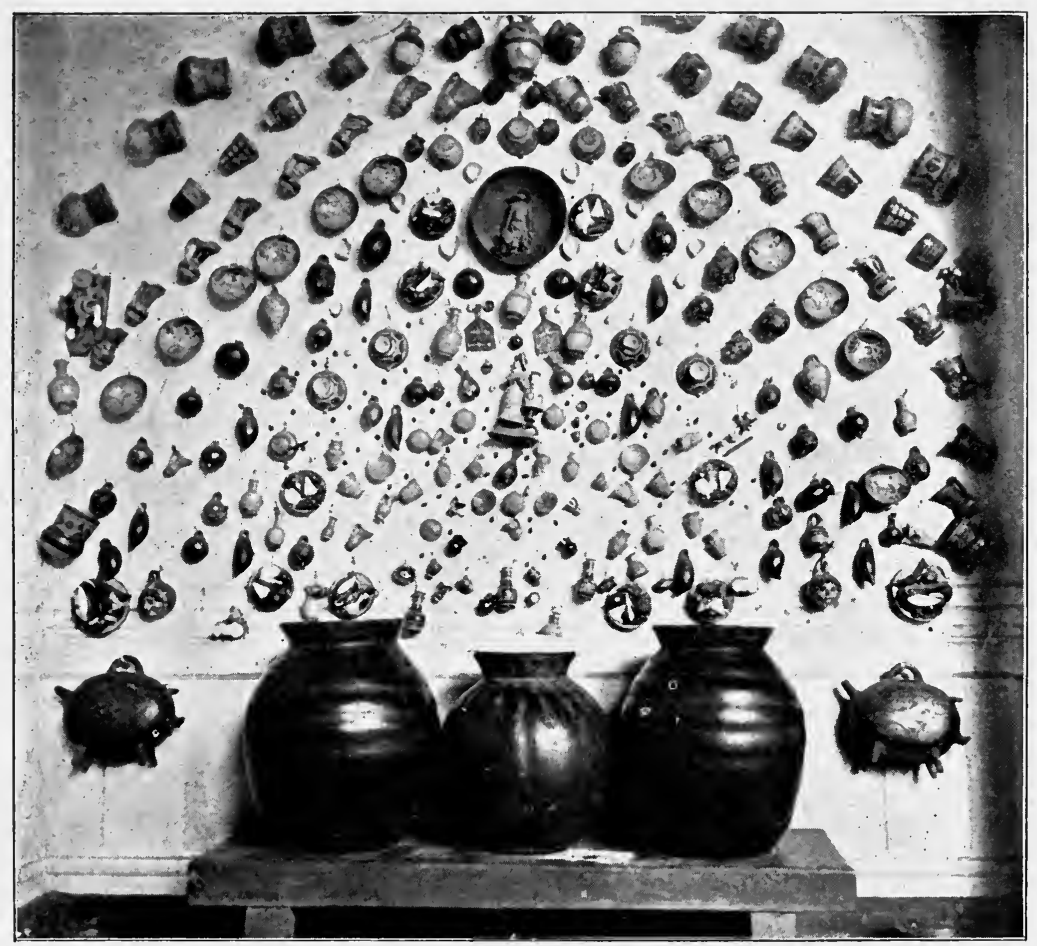

FIG. 1.-WALL DISPLAY OF KITCHEN POTTERY: SILAO. (No. 27.) 



\section{RAG FIGURES :}

The rag figures made by Indians in the City of Mexico have been famous for many years. Brautz Mayer says :*

"Until recently there were in the City of Puebla two sisters remarkable for the manufacture of figures from rags. These ladies were of respectable birth, and always commanded a ready sale for their works, which were sought for even in Europe. They moulded the figures of lumps of beeswax, covered the different parts of the body with cotton-cloth of colours suited to the complexion, and while the wax was yet soft moulded the features into the required expression, completing the representation with appropriate dresses. I have two of these in my possession, which, in point of character, are worthy of the pencil of Teniers. They represent an old Indian woman, scolding and weeping over her drunken son. The grief and age of the one and the tipsy leer, roll of the head, and want of command over the limbs of the other are rendered with indescribable faithfulness."

Such figures are still made, and represent the common types of the streets of Mexico.

31. Rag figure: Aguador or water-carrier. City of Mexico. 32. Carbonero or charcoal-seller.

,

\section{POTTERY FIGURES :}

The pottery ware of Guadalajara is the most famous in the Republic. It is sold at every public market, and many thousand pieces go annually to foreign lands. But pitchers, goblets, cups, saucers, plates, bowls, etc., are not the only forms into which it is made. As wax and rags at other towns so pottery here is made into figures representing types of every class. These are made by pure Indians, who have had no 
instruction; and they are strikingly lifelike. The most famous makers are named Panduro, a father and two sons; but there are several others who are nearly or quite as good. There are all grades of work. The best are unpainted figures, in careful detail, standing about 8 or 10 inches high. The originals are made with the moist clay, the only tools being the fingers and little sticks. After a satisfactory design has been made, it is used as a pattern, a mould is made and copies are pressed in this. The Panduros are quick to catch a likeness, and make many portraits, for tourists, from life.

33. Pottery figure, of good grade : unpainted. Cake-dealer carrying his wares in a tray upon his head.

34. Pottery figure, of good grade: painted. Labourer with load of bricks. For other examples of this better grade of pottery figures see Nos. 292-300, representing Tastoanes.

35-46. Smaller pottery figures of medium grade. An orchestra of eleven pieces and leader. The painting of these is unusually good for cheap work: the medium used is mulberry juice, which is said to be permanent. For other examples of this grade and workmanship, see Nos. 66-73 representing bull-fighters. For a still commoner grade of work see in Children's Toys, Nos. 128-130.

\section{MINIATURE FIGURES IN POTTERY:}

At a few places extremely small figures in clay are made. They usually represent types of common life, and are often mounted in small groups. They are not pressed in moulds but are hand-formed. A bit of clay taken in the fingers is roughly shaped, after which the finishing is done with a little pointed tool of bone. They are mounted on wire and then baked in a gas jet. The colors are then applied. These little figures not more than an inch in height present a marvellous amount of detail. They may be mounted in groups 
upon simple tablets of wood, or on little supports set against a backing of onyx, or in a nutshell-favorites being the Madeira nut and a small cocoanut. When mounted in groups these usually represent some scene in common daily life. The seven groups in the collection were made in Puebla.

\section{Scene at Santa Anita :}

The Indian village of Santa Anita, just outside the City of Mexico, is famous as a place of gaiety for common people and for its chinampas or floating gardens. These are little rectangular patches of fertile soil, separated from one another by narrow canals all of which ultimately communicate with a large canal called the $V^{i}$ ga. Over this waterway there daily pass hundreds of canoes loaded with vegetables for the city market. The houses are light constructions of cane with thatched roofs. The business part of the town consists of a few drinking places-shops of ordinary Mexican construction facing or near to the Vega. The group shows two canoes on the water, a musician playing a guitar to whose music a couple are dancing the jarabe, another musician seated, a couple making love and a woman with an intoxicated lover.

\section{An Indian Wedding:}

This is a favorite subject with group-makers. It is also a frequent dramatic subject for celebration among the common mestizo population, who seem to think it most comical. While varying from tribe to tribe, the following condensed from the account given by the school teacher at Cuauhtlantzinco, Puebla, where the current speech is Aztec, will convey some idea of the performance. The town fiscales, with their official staves in their hands, go to the house of the bride-to-be, gain the consent of the parents to the marriage, and then formally inform the priest. The following Sunday, the same officials 
conduct the young couple to confession and communion, and on Monday to the marriage service.

The godparents give the bride enaguus and a rebozo. The enaguas (dresses) cost about a peso a yard and are some ten yards long: the needle work upon them costs some three or four pesos. The rebozo (head shawl) costs three or four pesos. The young couple wear crowns of natural flowers: these crowns are called cluveles and are high, and the flowers composing them are massed closely.

After the marriage ceremony, the authorities of the town are invited to the house of the bride: the guests also gather there. A breakfast is served, consisting of pork tamales and bread. After eating, all adjourn to the house of the bride's godfather for dinner. This consists of mole of turkey, cigarettes, liquor and pulque. After eating, all go to the house of the bridegroom for a second dinner. Before eating this the young couple kneel before an altar: the parents and relatives, with the town fiscules at their head, stand by. The fiscales, giving their staves to the young couple, exhort them to live properly, to observe their matrimonial obligations, etc. During the dinner which follows there is music on stringed instruments.

The whole company now returns to the bride's home. The groom's parents fill a great basket with food-a whole turkey, half a pig, a vessel of mole, many tamales, etc. A man carrying this upon his head leads the way, while the rest follow with music, song, and dancing. Arrived at the house the basket and its contents are presented to the parents of the bride, and dancing begins. A woman standing near with a basket of flowers throws handsfull of these over the dancers. When these flowers are all gone, bunches of grass (brooms) are given to the participants. The dancing continues for two or three hours, when the party returns to the house of the bride- 
groom. As she leaves her home for ever, the young bride receives a parental blessing amid the tears and sobs of the bystanders. Her people then load two or three great baskets with the girl's property-dress, pottery, griddle, metate, etc. These are ostentatiously carried at the head of the company to the house of the groom, where they are set down as symbolical of the woman taking possession of her new home. Dancing is then resumed and kept up until dawn.

If the girl's godfather chooses, he gives a dance on the Sunday after the wedding. This is the formal close of the celebration.

\section{Scene in school:}

The details of blackboard, benches, study-desks, teacher's table and boy in disgrace are all quite true to life as seen in an ordinary village-school.

50. Cock-fight.

51. Bull-fight:

The moment represented is when the bull has thrown a horse upward, dismounting a picador, who is falling. Two capadores with their bright capas and an attendant are trying to distract the attention of the bull in order to save their companion.

\section{Ranch life:}

The mayordomo is at the door: two caballeros pass, two donkeys_ " burros"-carry loads, and a cargador has a pack on his back. A musician thrumming a guitar and a woman grinding meal on a metate are the other most important personages.

53. Nacimiento: Nativity (See Nos. 425-432).

The composition is extremely simple. A stable is rudely represented, over the open front arch of which hovers an angel. 
On a slab presumably representing a manger lies a naked babe. At the head and foot kneel San Jose and Maria. A cow and a donkey rest in the stable.

The little groups arranged in nutshells are also from Puebla. Great skill and patience are shown in some of these.

54. Group of figures in a half shell of a Madeira nut: Two men with fighting cocks are represented.

55. Figure in a half shell of a Madeira nut: A tlachiquero or' pulque-gatherer.

The agave plant, the gourd for gathering the sap (acocote), the skin-bottle for storing it are all perfectly detailed, as is the dress of the man-that usual to the Indian peasant class.

56. Man with fighting cock in hands : placed in half of a hazel nut or filbert shell.

57. Scene on the Viga Canal. Woman paddling in canoe full of vegetables to murket. In hazel nut or filbert shell

58. A blind man walking. Enclosed in a half shell of a piñon nut.

The piñon is the seed of a species of pine. It is very sweet and a great favourite in Mexico. This is less than half the size of a hazel nut or filbert, and is the smallest nut generally used for such figures or groups. 


\section{SHOP SIGNS AND NAMES.}

There is but little in the way of characteristic shop signs in Mexico. Red flags are hung out at butchers' shops, when freshly-killed meat has been received. Pulque shops are frequently distinguished in some way when fresh pulque has been received. The common method is to garland the doorway with reeds, and to hang a fringe of reeds across the upper part of the entrance. Pulque shops are often decorated with bright paintings, which may cover the whole front. These pictures represent drinking scenes, boating parties, rural festivals, and the like. Such painted fronts are common at Puebla, where also a special sign is hung out to indicate that fresh pulque has arrived. This sign consists of a round sieve covered with brilliant glazed or gilt paper, from which hangs a great mass of colored tissue paper strips: in the bottom of this sieve is pasted a picture of some pretty girl. This sign is hung out over the middle of the door-frame. Cholula, a town famous for its ancient pyramid, though but eight miles from Puebla, does not use such sieve signs. At the pulquerias there, fresh pulque is indicated by flags of red stuff, usually embroidered about the edges and hung from neat poles, which are tipped with gilt or silvered balls or ornaments.

59. Sign for fresh pulque: Puebla (photograph). 60.

61.

$" \quad " \quad$ Cholula: $"$

While distinctive shop signs are rare in Mexico, the names given to shops are curious and interesting. These are sometimes wonderfully appropriate, sometimes grotesquely suggestive. A few examples will illustrate them. 
Shoe-shop at Leon : El pie de Venus-the font of Venus.

Pulquerias :

Puebla : El rey que rabio-the mad King.

Guadalajara: Las hijas de Eva-the daughters of Eve.

The painting represents a family quarrel: an angry man grasps a bottle in his left hand: with his right he holds off an assailant: his wife stands with hands raised in horror, and the children weep.

Al cabo caen: They fall all the same. The painting represents a barrel on end, set a foot above the floor. A man is filling a glass at the faucet.

El Infiernito: the little hell. This was near one of the chief churches. The Government compelled it to take another name.

La reforma de los Estados Unidos: the reform of the United States. A miserable little shop in a back street.

Las memorias del Diablo: the memories of the devil.

La cruz verde: the green cross (sign of the Inquisition.)

Panaderias: bakeshops :

Sagrado Corazon de Jesus : sacred heart of Jesus.

Panaderia de la Santissima Trinidad: Bakery of the most sacred Trinity.

El Diluvia and La Torre de Babel : the Deluge, and the Tower of Babel, are drinking shops opposite each other.

La Esmeralda : the emerald, is the famous jewelry of the City of Mexico, while Las flores de la Primavera, the flowers of springtime, is a prominent dry goods house. 


\section{STREET CRIES.}

Street cries are numerous, characteristic, and curious in the capital city. So far as I know, they have never been carefully studied. It is impossible to enter here upon such a study. An interesting paragraph, published in 1858, may be quoted for preservation of customs of that date (Manual del viajero en Mejico, pp. 131-133. Marcos Arróniz: Paris, 1858. This is, by the way, copied after Madame Calderon de la Barca: see Life in Mexico, pp. 53, 54).

"The dawn of day is announced in the streets of Mexico by the sad and monotonous cry of a multitude of carboneros (charcoalsellers), who stand at the doorways and cry with all the force of their lungs: Carbosiu! (carbon señor) 'charcoal sir.' A little later is heard the melancholy voice of the mantequilla (butter) sellers, who without stopping in their march cry Mantequia . . . mantequia de á real y dia medio (Butter . . . butter at a real and a half). Cesina buena! (good salt beef) is the announcement with which the carnicero (butcher) interrupts him, with a harsh and inharmonious voice: this in turn alternates with the fastidious and prolonged cry of the sebera or woman who buys tallow from the kitchens, who placing a hand over her left cheek, shrieks into each doorway : Hay sebooooooo: (Is there tall-o-o-o-w ?) Hardly has she disappeared, when the cambista enters, an Indian woman who exchanges one effect for another, and cries in a lower key and without prolongation of syllables: Tejocotes por venas de chile! ... tequesquite por pan duro (Tejocotes for veins of chili . . . washing soda for hard bread). Tejocotes are small yellow fruits: veins of chili are the insides of red peppers. With this a buhonero, or perambulating dealer in notions, arrives, who having entered the patio cries out his long list of wares, in a penetrating voice, while he seeks the ladies with his eyes: Agujas, alfileres, dedales, tejeras, botones de camisa, bolitas de hilo? But he is rivalled almost before 
his echoes have died away by the frutero (fruit-dealer), who in thunder tones names over his wares. Meantime at the corner a woman sings this little lay: Gorditas de horno calientes, mi alma! . . Gorditas de horno! (Corncakes hot from the oven, my love! ... Corncakes from the oven!). The makers of mats or petates of Puebla appear to have no other market than Mexico to dispose of them: thus they all scatter themselves through the streets and cry out in a uniform manner: Petates de la Pueeebla! . . jabon de la Pueeeebla: (Mats of Puebla . . . soap of Puebla). In competition with these, those who sell the rush goods made at Hochimilco cry out in turn in rasping voices: Petutes de cinco vaaaras! Petates de á media y tlaco (Mats of five yards length ! mats at eight pence). Nor is midday free from these troublesome cries : a beggar mumbles blasphemies for a bit of bread; a blind man recites a miraculous romance for the same object; at the same time the penetrating cry of an Indian woman is heard, which laccrates the ears, announcing : Melcuiiiiii (melcocha) (honeycake); that of the quesero (cheesemonger) who with all the force of his windpipe gives forth : Regueson y melado bueno! . . . Requeson y queso fresco (curds and good honey... curds and fresh cheese); and the gentle clamor of the dulcero (vendor of sweets) who after his special nomenclature offers $a$ dos palan. quetas ... á dos condumios . . . caramelos de espelma . . bocadilla de coco (two for a cent seed candy cakes . . . two for a cent pea-nut bars . . . fine sugar caramels . . slices of cocoanut), narrative often interrupted by drunken tremulousness in his voice, or by the shrill cry (according to the age of the individual) of the numerous sellers of lottery tickets who offer for a half real el último billetito que me. ha quedado para esta tarde (the last little ticket I have left this afternoon) . . . and this 'last' never is finished. The same cries are common in the afternoon: but that of tortillas de cuajada (curd-tortillas) and the funereal lament of the nevero (ice man) who announces with sepulchral voice, $A$ los canutos nevadas! (ices in little cylinders) belong especially to this part of the day. In the rainy season, Indians run through the streets at their peculiar 
dog-trot, crying: No mercan nilatzilio, with which cry they announce their sale of jilotes (hot boiled corn) and the nueceras (nutsellers) theirs with the simple: Toman nues? (will you have nuts?). At night they cease, but others follow ; the chestnut-sellers in winter cry through the streets in a strong well-controlled voice : Castaña asada y cosida: castaña asada (chestnuts roasted and boiled! roasted chestnuts). The pateras (duck-selling women) with the pretty song, which they repeat every moment, some remaining at the corners; the juileras (crawfish-sellers) and those who sell tamalitos sernidos (fine flour tamales), and tamalitos queretanos (sweet coffee tamales), mingle their cries with innumerable others of still other sellers; an infernal hubbub which gradually diminishes as night advances. But the king of street-cries, the most powerful because it dominates all, is at noonday: A las bueeenas cabeezas calieeeentes de horno! (Good sheep-heads hot from the oven!)" 


\section{POPULAR AMUSEMENTS.}

Gambling devices of many kinds are used in Mexico. On fiestas or holidays booths are set up in the public squares, and are filled with persons trying their luck. On the sidewalks of the streets groups of common people crowd around some man who is conducting a simple game in such a way as to encourage the bystander to think that he cannot have bad luck. The whole matter of gambling and card-playing is being investigated by the writer, who for that reason includes no specimens or illustrations of it in the collection.

\section{BULL-FIGHTS :}

There is no necessity of here describing the bull-fight. More than enough accounts of it are readily accessible. A small series of articles will illustrate the things used by the fighters and the popularity of the sport.

\section{Rosa:}

As the bull is let into the ring a short dart is plunged into his shoulder, This is surrounded by a circle of paper and has streamers of coloured tissue-paper attached. It serves two purposes: (a) the pain from its thrust causes the bull to enter the ring with energy and spirit; (b) the colours and form of the rosa often serve to show from what hacienda or breeding farm the bull comes.

Banderillas: After the bull has been excited by the capeadores who wave brightly coloured mantles at him, the signal is given for the banderilleros to appear. These men are supplied with darts, iron-barbed on the end, with which the bulls are tormented. The aim is for the banderillero to wait about making his thrust until the beast is lunging directly towards him with 
his head lowered. Then, at the critical moment he reaches over the lowered horns and tries to thrust one dart deeply into each shoulder of the bull, and instantly leaps to one side to escape destruction. Banderillas are always used in pairs and are gaily decorated with coloured tissue-paper. They serve to infuriate the bull for the final operation of the matador, who uses a slender sword in killing the terrified, wounded, and furious animal. The usual rule is to leave the bull to the torture of the banderilleros until four pairs of the darts have been planted in him.

63. Pair of Banderillas: Toluca. 64.

65. Pair of Banderillas with powder cracker attachment: used when a bull is found to have little spirit.

They are usually cried for by the enraged and disgusted audience. Immediately on being thrust into the animal, these begin to explode, and by terrifying the creature cause it to show signs of increased energy.

Figurines of pottery representing bull-fights are favourite designs. The series represents a set of actors in various sorts of bull-fights. It would be rare that the whole series could be seen at any one time or place. All from Guadalajara.

66. Picador: mounted; who wakes up sleepy animals with his long pole, iron-pointed.

67. Capeador: as he enters the ring with capa over shoulder.

67. Capeador: using capa.

68. Banderillero.

69. Matador.

70. Bulls.

The above are regular performers and would be. seen in every ordinary bull-fight. 
71. Clown.

72. Country bull-fight: capeador on horseback.

73. Country bull-fight: fighter rides a bull.

The ancient art of feather-picture-making is gone. At Patzcuaro are still two men who make moderate work, over prints, with humming-bird feathers; but the truly artistic independent free work of old Tarascos and Aztecs is past. Coarse, common work over prints is much done in the City of Mexico, chiefly to supply tourists with souvenirs: Favorite designs represent bull-fights and cock-fights.

74. Bull-fight: featherwork picture. 75. Bull-fight: featherwork picture.

\section{COCK-FIGHTS :}

are popular in most of the cities of Mexico. It seems as if they were more thoroughly enjoyed by the Indians than by the half-breeds. All classes, however, attend them. Special pits are constructed. Sundays and Mondays are the chief days for fights.

76. Basket in which cocks are carried to cock-pit.

77-78. Knife-Spurs, attached to the legs of fighting cocks. Of fine steel. They go in pairs, one for each bird. The size to be used is matter of agreement and previous announcement.

79-80-81. Scenes in cock-fight: feather-work pictures. These come nearest to artistic character of all modern feather-work pieces.

\section{PUPPET-SHOWS :}

are a common amusement. Zacatecas has some celebrity in this direction, but Alejandro Aguirre, who appears to be the chief man in that line at that city, insists that the 
great artist is Leandro José Rossetti Herranda, who lives in San Luis Potosi. Aguirre makes his own puppets, and has some hundred and eighty figures representing different characters. The figures are jointed and made of wood. They will average nearly eighteen inches in height. In make-up and dress considerable attention is given to character-portraiture. The figures range from fine ladies to dancing girls, from drunken newsvendors to priests, matadors, and officials. Threads are attached to the various articles of clothing for the manipulation of the figures. These are gathered together at the top into a mass which is wound about a cross of wood. The figures are played upon a platform. At the back of this is a screen painted with scenery, which rises to a height of some five feet or more. Behind this is a platform on which the men who play the figures stand. One person is needed for the manipulation of each figure. These are let down from above on to the platform in front of the screen. Their movements are astonishingly lifelike. They are made to walk, run, move their arms most naturally, dance, embrace, and engage in all sorts of pranks. The players are out of sight, a curtain falling to the top of the scenes and a little in front of them quite concealing them from the spectators. Each manipulator speaks for his puppet in the tone and manner deemed appropriate. Regular plays are composed and rendered. The performances are given usually in regular theatres. Handbills announcing a varied entertainment are distributed. Admission in considerable towns ranges from one to three reales-3d. to $9 d$. The managers sometimes write their own plays, but several printing houses have published such plays, some of which are as well known as Punch and Judy. Sr. Herranda has published a number of puppet plays. They are usually comic, and often contain rude and extremely coarse allusions. The common Mexican audience is not refined; and such allusions, however 
broad, are met by roars of laughter. The puppets in the collection are the entire company in a little two-act comedy called El Borracho Mexicano, written by Alejandro Aguirre of Zacatecas. This has not been printed, and is characterised by the features above mentioned.

82. Photograph of puppets.

83-88. Puppets.

89. MS. El Borracho Mexicano:

"The Mexican Drunkard," a two-act puppet comedy. The hero is an unscrupulous drunken newsvendor, who has keen native wit. He gets into a brawl on the street, is arrested, and is dragged before the judge. He intentionally misunderstands the questions and admonitions of the magistrate and answers them with irrelevant or insolent replies.

90. Teatro Infantil: a series of penny plays intended for child-performers or puppets. Some of these are extremely popular. 


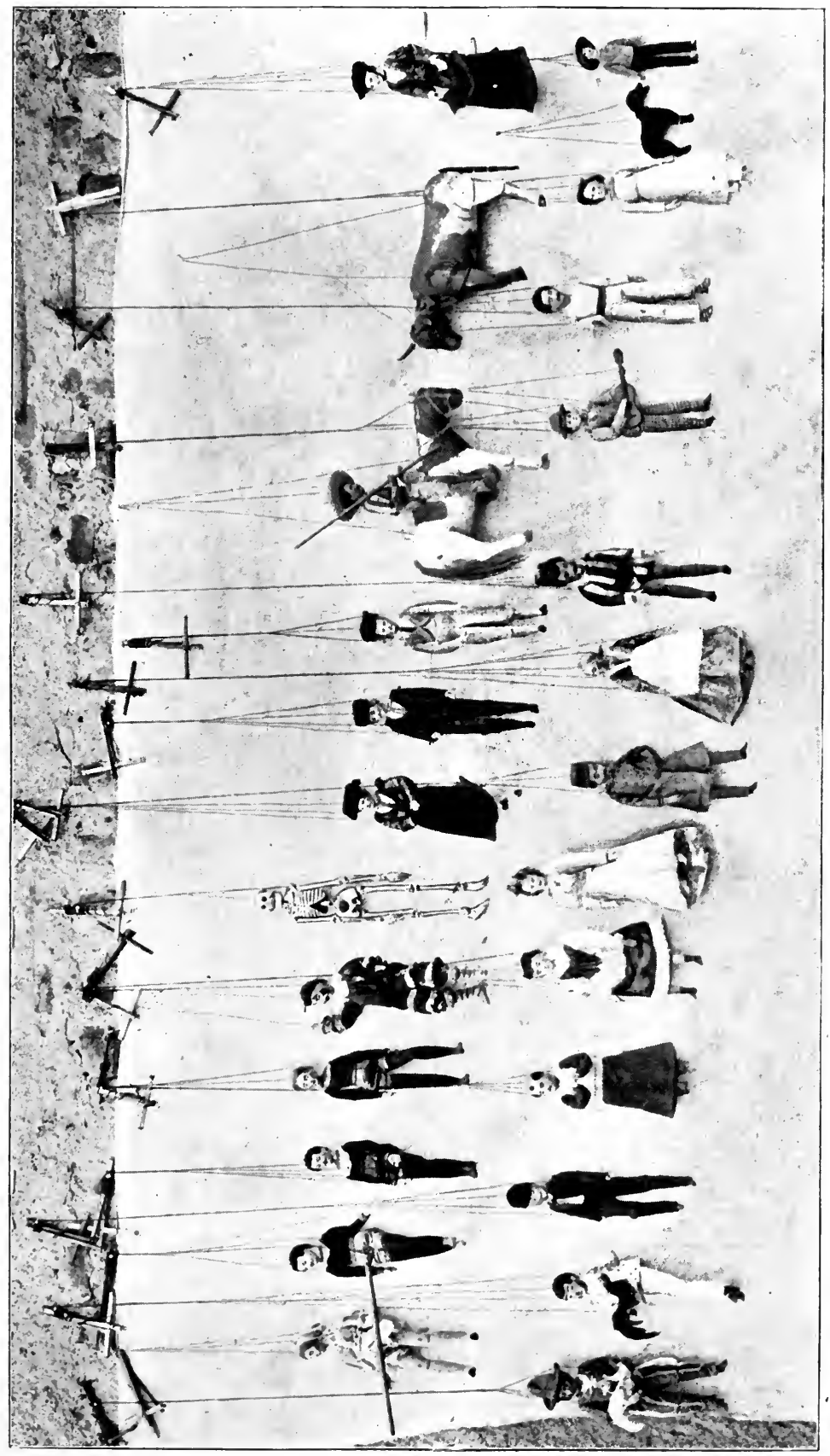

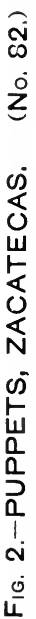





\section{GAMES OF SKILL FOR ADULTS.}

\section{GHESS (Ajedres):}

Is much played. The sets of pieces are often fanciful or artistic. The two sets in the collection were made in Puebla.

91. Set of Chessmen: Spaniards and Cubans.

Until the intervention by the United States, Mexican sympathy was strongly in favour of the Cuban insurgents. This sympathy showed itself in many ways. This set of chessmen illustrates it.

92. Set of Chessmen: national.

One series of pieces represents the Republican, the other the Imperialist parties. Portraits of Hidalgo, Juarez, and Diaz are set against Maximilian, Carlota, and the Generals of the French Intervention.

\section{PLAYING GARDS (Naipes):}

93. Pack of playing cards: ordinary. Forty cards make up the pack. The suits are oro (coin), basto (club), espada (sword), copa (cup).

94. Pack of playing cards: national designs. The cup, sword, and club are copied from old Aztec patterns, and the coin is a copy of the famous Calendar stone. The figures on the court cards are Indian. 


\section{CHILDREN'S TOYS AND GAMES.}

In this description the following crude classification is adopted:

Miniatures of real life.

Toys. $\left\{\begin{array}{l}\text { Simple toys. } \\ \text { Puzzles. } \\ \text { Toys used in some game. }\end{array}\right.$

Games. (\{ Outdoor Sports.

$\left\{\begin{array}{l}\text { Indoor Sports } \\ \text { iboard games }\end{array}\right.$

Rhymes and songs.

Counting-out rhymes̀.

\section{MINIATURES OF OBJECTS USED IN REAL LIFE :}

There seems to be an unusual fondness among Mexicans for making in miniature the tools and implements of real life. These are sold as children's toys, and a complete collection of them would almost form an ethnographic museum.

95. Kitchen pottery: pitcher, eared bowl, mixing dish, frying pan. Of the grade of the cheapest ware: glazed. 4 pieces. Puebla.

96. Similar: smaller. 6 pieces. Puebla.

97. Similar: still smaller. 8 pieces. Puebla.

98. Kitchen pottery: pitchers, mugs, plate bowls: green and brown ware: glazed. 6 pieces. Guadalajara.

99. Kitchen pottery: red glazed ware. Two pieces. Guadalajara.

100. Kitchen pottery: red polished ware: pitcher. Guadalajara.

101. Kitchen pottery: Miniatures of the sweet-smelling ware. This, made of a special clay, exhales a sweet odour 
when water is first poured into it. The property disappears in time, but is quite persistent. Three pieces. Guadalajara.

102. Comallis or griddles: The earthen griddle, used for baking corn cakes or tortillas, bears the Aztec name of comal. The miniatures are copies in material, form and glaze. Two pieces. Guadalajara.

103. Brasero:

The Mexican stove is a small brasier of earthenware, in which a fire of charcoal is kindled: this may be fanned with a fire fan. Plain red ware.

104. Similar: smaller. Glazed ware. Puebla.

105. Fire-fan: Puebla.

106. Metate and Metlapilli: The Metate (Az. Metatl) is the stone on which the maize is ground to meal. The Metlapilli (Az.) is the stone, held in the hand and with which the grinding is done. 'The miniature, of black pottery, resembles the actual dark igneous rock. Puebla.

107. Metate with Metlapilli and two enchiladas (corncakes) ready to be baked. Brown and green pottery. Guadalajara.

108. Kitchen Wall Bracket, supporting a full outfit of knires, wooden spoons, forks, chocolate muller, etc. Puebla.

109. Wooden Dough-Tray: Puebla.

109. Rebozo: scarf or shawl worn over the head and shoulders : universal among the lower class mestizc women. As folded and done up for sale. Puebla.

111. Scrubbing brushes: Puebla.

112. Miniature objects cut in bone: chocolate muller, weaving block, spool of silk, hair parter, combs, cup. Puebla.

113. Miniature toys: even toys themselves are made in miniature : peg and ball. (For full sizes see Nos. 155-157.) Puebla. 
114. Miniature toy: top. (For full sizes see Nos. 159, 160.)

Señor Alatriste of Puebla finds a sale for little earthenware representations of Indian houses and outbuildings.

115. Indian hut of Tlaxcala.

116. Indian hut of Tlaxcala with cuezcomate and stone wall.

117. Indian hut: with temascal.

118. Cuezcomatl : Tlaxcala.

119. Cuezcomatl: Two vase types, Tlaxcala.

120. Temascal of Tlaxcala

121. Indian hut: in hot land.

Indian houses in the towns in the State of Tlaxcala are usually built of stone or of adobe sun-dried bricks. They are usually in an enclosure surrounded by a stone wall. Within this enclosure are frequently two forms of lesser structurescuezcomates (Az. cuezcomatl) and temascals (Az). The former is a storehouse for maize and beans. It is a more or less vaseshaped building of clay or clay and stones, rising at times to ten feet in height, and often with a cover or roof of thatch. The temascal is a sweat-bath house built of stones and adobe and dome-shaped-perhaps three feet or so in height.

\section{SIMPLE TOYS :}

Figures :

Small figures of animals, made of baked clay and wire, carefully coloured and notably life-like.

\section{Deer.}

123. Burro: donkey.

124. Horse.

125. "

126. Bull. 
127. Bull:

Puebla.

128-130. Very crude, cheap, animal figures in pottery : glazed. Coyote, horse, bull, goat, cat, turtle, tarantula.

While very coarsely made and badly coloured, each has some absolutely identifiable characteristic. Guadalajara.

Whistles:

131. Simple whistles of plain pottery. Guadalajara.

132. Mań.

133. Woman.

134. Rabbit.

135. Goat.

136. Dog.

137. Cat.

138. Sheep.

139. Sheep.

140. Burro.

These awkwardly shaped and glaringly painted animals are made by the same workers and sold at the same shops as the carefully made figures of Nos. 33, 34, and 292-300. Guadalajara.

141. Siren: Guadalajara.

142. Siren

The following explanation is given of the siren. A girl once gave her mother much trouble by bathing in the sea. Though repeatedly told not to do so, she persisted. One Holy Friday she declared her intention to bathe. Her mother remonstrated earnestly, because it was Holy Friday. The girl, however, was headstrong. The mother cried out: "Well, if you do 
bathe to-day, you will turn into a fish." The girl bathed, and became the siren.

\section{Savings-Banks :}

Savings-banks of earthenware are made in many forms of fruits and animals. Among the more common are bananas, iicamas, limas, oranges, tomatoes, chilis, pigs, horses, lions, dogs, and burros. They illustrate the wide use of pottery. The ancient Mexicans made almost everything in earthenware, and their successors almost equal them in this respect.

143. Earthenware savings-bank : form of granada, or pomegranate. Guadalajara.

Naguales :

Among the figures made as toys for children these are the most curious. They represent a four-legged animal, with no tail, a woolly fleece and a human face. It is usually supplied with some sort of a cap, and bears upon its back the booty which it has stolen from some house. Many curious ideas prevail regarding these creatures, whose existence is seriously believed in. Children are frightened into good behaviour by threats of naguales. As examples of common belief the following stories will suffice.

When one is believed to be approaching, the house isdeserted and left for it to clean out. They have sometimes iron claws, and sometimes put something on their feet to enable them to climb up trees. At Autlan, a nagual really appeared once. The place was deserted, but two drunken fellows quarrelled about it-one claiming it a diablo, the other a nagual. They together attacked it and killed it. It turned out to be a couple of men dressed up to represent the usual idea of the beast. The government gladly let off the killers.

On seeing a piñata representing a distorted human figure 



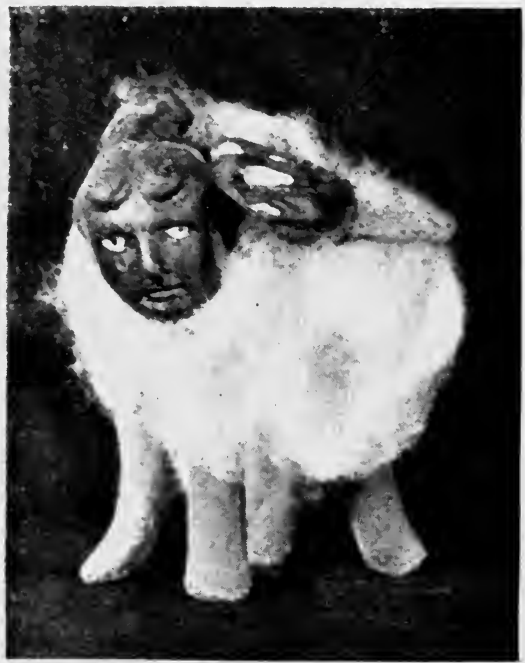

FIg. 3.- NAGUAL: GUADALAJARA (Nos. 144-148.)

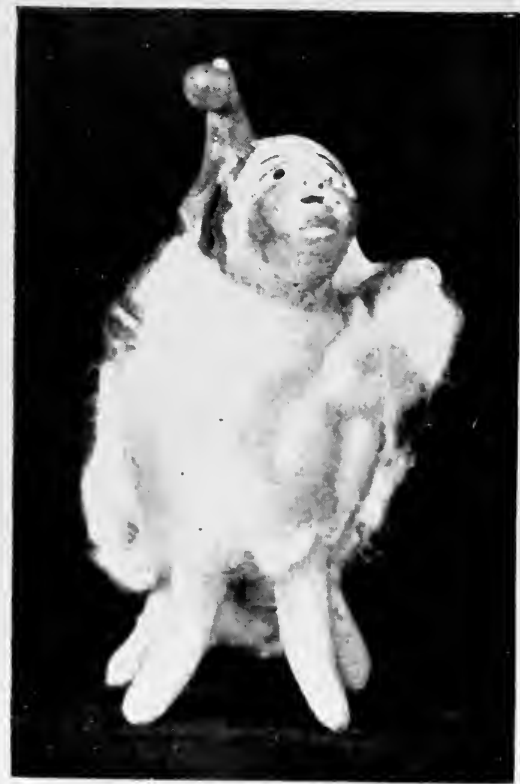

FIg. 4.-NAGUAL: GUADALAJARA. (Nos. 144-148.) 
covered with a wool of black tissue paper. Mr. Powell's maid said it was just like a bruja or nagual which was burned in Orizaba this past year. This nagual had given much trouble in robbing, taking away household articles and food materials. It was hunted and killed in a corral. It was then taken and burned. When first pursued it went on all fours, but when finally attacked it stood up like a man. It was covered with a black fleece. The girl saw it after it was killed, but before it was burned. It was the size of a man.

At Cholula, Manuel once saw a nagual. He says that when first seen a nagual is the size of a coyote, but that as it approaches to rob one, it grows to be the size of a burro. It can be trapped. He saw one on his own street, Calle de Jerusalen, through a crack in the door. It had lain in wait and was about to attack some rich ladies. It was, however, watched, and four men from as many directions rushed out at one time, and each made a cross at his proper point in a circle surrounding the nagual. It was now impossible for the creature to escape, and he waited-as paralyzed-for the officers, who quickly came and took him away.

They are believed often to have power for magic from the devil. One man relates that when he was a small boy in the State of Guanajuato ( $H a c^{\circ}$ de Burros) an old woman had three fat pigs. A man who desired to steal them did himself up in sacking with wool fleece, claw-ed his hands, rubbed matches on his palms and around his eyes, and visited the old lady's lonely home. He got her pigs, while she died shortly from fright, convinced that she had seen an agent of the devil.

144. Nagual : pottery. Wears a green cap, and has stolen a jar of honey and a jicama.

145-146. Naguales: pottery. Much alike, with cleft caps. 
One carries a metate and a jicama, the other a metate and a comal.

147. Nagual: pottery. Pointed red cap with green tip; carries a metate and a jicama.

148. Nagual: pottery. Negro with a red cap; carries a great beet and a jar of honey.

All these naguales are from Guadalajara.

149. Nagual : pottery. Much larger. This belongs as truly to the series of muertos (Nos. 301-420). The creature bears upon his back a skeleton, which wears a red cap, flies a flag, and carries a cut of watermelon. Guadalajara.

It is probable that these naguales are related to ancient ideas of sorcery. The name nagual is still used in parts of Mexico and Central America as the equivalent of witch, sorcerer, or medicine man. One of the commonest powers of these persons is transformation. The idea and the word are both ancient and aboriginal. In Dr. Brinton's Nagualism we read several passages from old writings about naguals. Thus:

"There are magicians who call themselves teciuhtlazque, and also by the term nanahualtin, who conjure the clouds when there is danger of hail, so that the crop may not be injured. They can also make a stick look like a serpent, a mat like a centipede, a piece of stone like a scorpion, and similar deceptions. Others of these nanahualtin will transform themselves to all appearances into a tiger, a dog, or a weasel. Others again will take the form of an owl, a cock, or a weasel ; and when one is preparing to seize them, they will appear now as a cock, now as an owl, and again as a weasel."

(Fray Juan Bautista: 1600.

Brinton : 1.c. p. 6.)

"Truly he was a wonderful king (Gugumatz). Every seven days he ascended to the sky, and every seventh day he followed the path to the abode of the dead; every seven days he put on the 


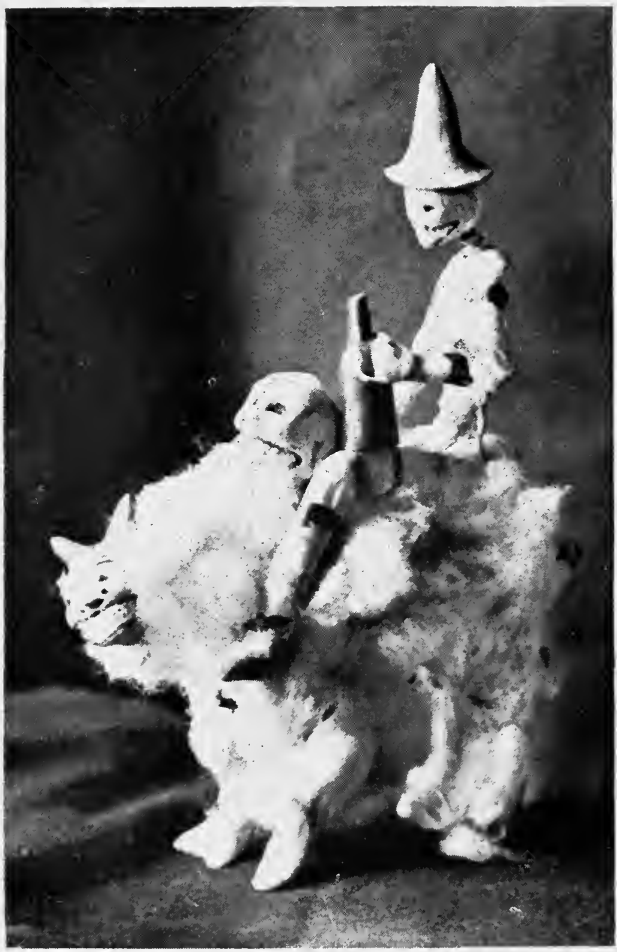

FIG. 5.-NAGUAL AND MUERTO: GUADALAJARA. (No.149.) 



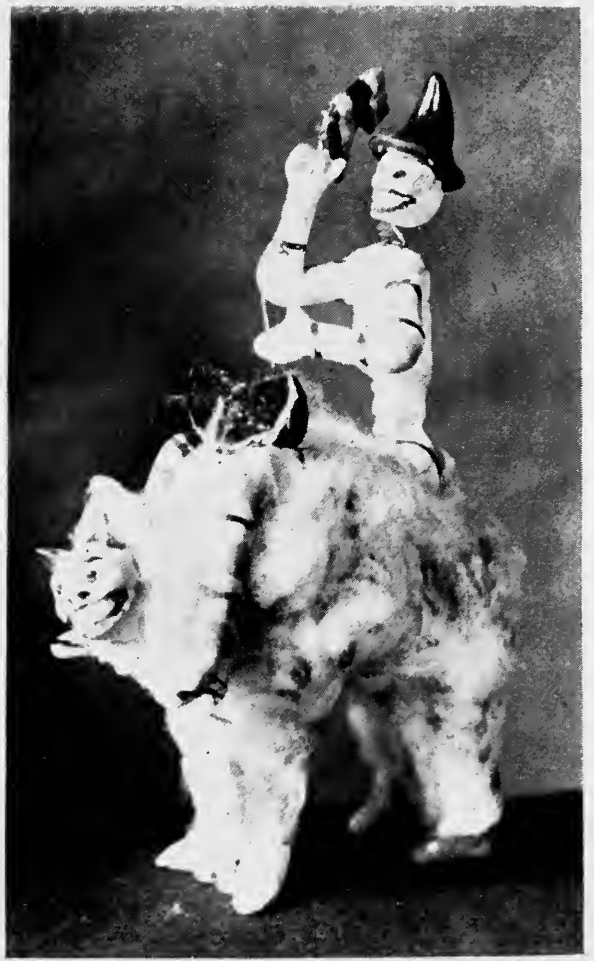

FIg. 6.-NAGUAL AND MUERTO: GUADALAJARA. (No 149.) 

nature of the scrpent, and then he became truly a serpent : every seven days he assumed the nature of an eagle, and then he became truly an eagle: then of a tiger, and he became truly a tiger: then of coagulated blood, and he was nothing else than coagulated blood."

(Le Popol vuh., p. 315. Brinton, p. 25.)

"Father Bartolomé de Baeza, cura of Yaxcaba in the first half of this century, reports that an old man, in his dying confession, declared that by diabolical art he had transformed himself into an animal, doubtless his nagual."* (Brinton, p. 25).

In these children's toys we have undoubtedly the shadow and representation of the ancient conjuror with his power of beast-transformation.

\section{Rattles :}

Children's rattles are made of many materials and in a variety of forms.

150. Rattle of straw: in shape of a bird. Puebla. 151. Rattle: pottery. Gourd shaped. Guadalajara.

\section{Gourds :}

These are lacquered at several towns in the hot country. With the seeds left in, they often serve as rattles. Little bowls cut from them are miniatures of larger bowls in common use. The gloss is obtained by. a putty-like mass made from an insect-a species of coccus.

\section{Gourd : lacquered. State of Guerrero.}

153. Bowl: made of lacquered gourd State of Guerrero.

* This last use of the word nagual requires a word of explanation. Among some tribes of Southern Mexico ard Central America the word nagual also means an animal companion and guardian. Each child was supposed to have such a nagual. 
154. Tumbling figures: Mexico.

155. Peg and ball: Puebla.

156.

157.

"

158. Rotating Disk: Puebla.

159. Humming top "

160. Top

,

161. Whizzer or Hummer: Cholula.

\section{Kites :}

Kites are much flown by boys and are made in several different forms, each with its own name. Those in the collection were made on purpose for it by Manuel Gonzalez, a Cholula boy Those made and sold in the shops often bear crude and comic pictures with accompanying inscriptions, conspicuous alike for their faulty spelling, and the corrupt forms of the words. To one form-the cocoles-a flapping sheet of paper is attached which produces a humming sound and is called a resumbadora. Cutting the string of an opponent's kite is a common practice. It is done by means of a specially-shaped little knife, called a media luna (half moon), which is fastened to the tail of the kite.

162. Kite! palomita. Cholula.

163. " cubo

164. " barillito "

165. " quadrado "

166. ," cocoles: with resumbadora.

167. Media Luna: Puebla.

A very pretty bit of writing by one of Mexico's most famous litterateurs, Maria Roa Barcena, deals with kite-flying, and compares life's struggles and experiences with those of boyhood kite-flying. The sketch is entitled Combates en el aire, and in the course of it occurs the following passage: 
"The preliminaries of the sport dated from the manufacture of the kite. The commonest were either parallelograms or pandorgas of paper or cloth, according to the size and importance of the toy, with the frame and cross-sticks made of a strong and flexible cane called otate, with flaps of gut or parchment, or cloth at the upper and lower edges, which were slightly curved; or bore the name and form of a cubo, with only three cross-sticks and a broad fringe of paper or cloth at the right and left. Both kinds were usually gay with the colours of our flag, or were decorated with figures of Moors and Christians, birds and quadrupeds. The tails were extravagantly long and formed of strips of cloth tied crosswise, at intervals, along a string, at the end of which was a tassel of rags : midway of its cord were usually the knives -terrible in the battle between two kites : they were two razoredged cock-spur knives, projecting from the sides of a central shaft of wood, with which their bearer cut the string of his opponent, which, thus abandoned to its fate on the wings of the wind, went whirling and flapping through the air, to fall at a considerable distance. Night did not put an end to the sport; there were messenger lanterns of paper hung from a great wheel of cardboard, through the central hole of which the kite-string passed, which, impelled by the wind, were sent up nearly to the kite with their candles lighted."

\section{Jointed Toys and Jumping Jacks :}

In great variety are made in various districts. Silao and Irapuato are however somewhat famous for these, and sellers of them meet all trains passing the two stations. The chief buyers are natives of the lower class.

\section{8-175 Jointed Toys: Silao.}

168. Man with dancing bear: two pieces.

169. White man playing guitar: two pieces. 
170. Man dressed in furs playing guitar.

171. Jumping Jack: Negro in furs.

172. Man : in charra dress, on horse.

173. Clown : when shaken, it squeaks.

174. Father Time: figure in pith.

175. Devil : figure in pith.

\section{CHILDREN'S GAMES:}

Outdoor Sports and Games with Rhymes and Songs :

Toro Entero: The bull-fight is carried out, often in full detail. Some will sit by on an elevated place and furnish the music: a juez may be chosen. The bull may be penned. The fighters go through with the procession: capeadores, banderilleros, matadores work in succession; the bull finally killed, the mules are called for to drag him out. No game is a greater favourite, and it may be seen played by street-boys in every plaza. In such cases, while no attention is paid to order and detail, much of the action is lifelike. Tattered serapes, ragged jackets serve as capas, and any stick answers for a banderilla or an espada.

Toro Chicho: One boy takes the part of bull; the rest are fighters and make sudden movements and thrusts at him. On his part he tries to strike them fairly on the back with his hand. One so struck is at once the bull. It is lively work.

El leon $y$ el tigre: (lion and tiger.) Two boys are selected as the lion and the tiger: the rest are cazadors (hunters) and arm themselves with sticks and shields. Attacks are then made, which are very real. A player once thrown or knocked down on his back is dead (muerto.) The game continues till both animals or all the hunters are dead. 
Momita: (= blind man's buff.) After a person is chosen and blindfolded, two of the players take him by the hands and lead him forward a few steps; he then gives a jump, and they turn him around two or three times; they then greet him-Que has perdido? (What have you lost?) He replies -Una aguja y un dedal (A needle and a thimble). They ask -Ruido o silencio? (Noise or silence?) He replies. In case he says ruido, they clap their hands to help him locate them. While he tries to catch one of them they constantly grab at and pinch or pull him. One caught takes his place.

Caballero: (Cavalier.) The players, divided into equal parties, form two lines facing. The first pair carry on a dialogue as follows :

(a) Caballero, Caballero.

(Cavalier, Cavalier.)

(b) Señor, Señor.

(Sir, Sir.)

(a) Se le cae su casa encima.

(Your house is falling down.)

(b) Correré para la sala.

(I will run out by the hall.)

(a) $Y$ si se cae la sala?

(And if the hall falls?)

(b) Correré para la recamara.

(Run out by the wardrobe.)

(a) $Y$ si se cae la recamara?

(And if the wardrobe falls?)

(b) Correré para la corridor.

(Run out by the corridor.)

(a) Y si se cae la corridor?

(And if the corridor falls ?)

D 2 
(b) Correré para la cocina.

(Run out by the kitchen.)

(a) Y si se cae la cocina?

(And if the kitchen falls?)

(b) Correré para el corral.

(Run out by the corral.)

(a) Y si se cae el corral?

(And if the corral falls?)

(b) Correré para el trascorral.

(Run out by the rear-corral.)

This order of rooms must be carefully observed in the replies. In case of a blunder either in question or answer, the other one says to the blunderer:

Lleva me à manches.

(Carry me on your shoulders.)

The blunderer must then carry his opponent to a spot apart where he sets him down. The carrier is called a burro (donkey), and returns to his place in the line; the other one is successfully out of the game. The next pair of players take up the dialogue, and the game goes on.

Coyote: (coyote or wolf.) One player is the coyote, the rest are gallinas (hens). The coyote stands to one side while the rest form a circle with joined hands. They then begin to whirl around and cry out: Coyote por donde vas? (Coyote, where are you going?) He rushes out, and tries to seize one and drag him out of the ring. The others cannot drop hand-hold, but kick vigorously as they pass near him, to keep him off. The game is kept up until but one gallina is left. He becomes coyote in the next game.

Culebra: (snake.) One player is aguililla (a little eagle). The rest in order of size take hold of each other by the top 
of the trousers or the bottom of the coat, and form a long line, the snake. The largest boy at the head of the column stands facing the aguililla. The following dialogue takes place :

Ag. Por donde sale el sol? Where does the sun rise? Cul. Acu. There.

Ag. No! aca. No! there.

Thereupon as if in great anger over the contradiction they begin to play. There is much yelling and waving of hands at each other between the snake's head and the little eagle. The latter tries to seize the little fellow at the serpent's tail and tear him from the rest: he does the same to the next, and so on. He may, if he can, tear away two at once. He runs the risk, however, always of being caught in the serpent's coils. If he eats a considerable number of the others he gains: in case he is caught and crushed, the serpent wins.

Tlaco de Queso: (Half-pennyworth of cheese.) 'Two persons only play. One sets a stick up in the middle of the street; the second throws a stone at it, trying to dislodge it and make it fly as far as possible. The one who set the stick at once runs to it, places it on the top of his right foot, and must so carry it, without dropping it, back to where he had set it up. Until he gets it there, the other player has been running backward as fast and as far as he can, stopping as soon as the other has done his task. The first must then carry the second on his back, as far as the latter has been able to run. So long as a thrower can succeed in hitting the stick he continues to throw: when he fails, the other takes his turn. 
Bebe leche: (drink milk.) A diagram is drawn upon the ground or pavement. Each part has its name.

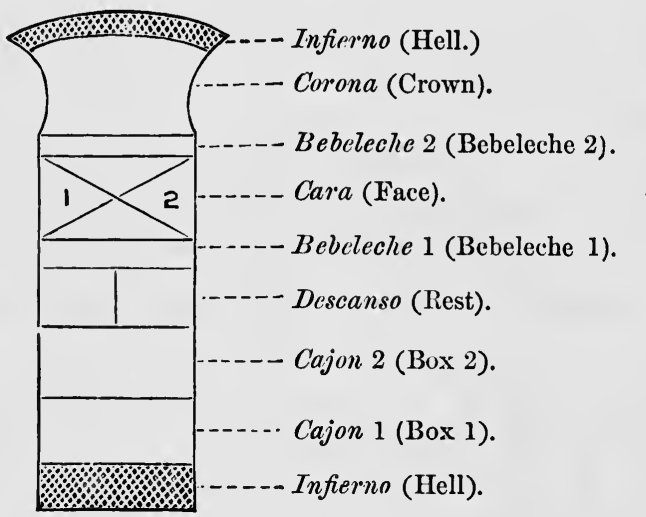

The Cara (face) is itself divided into four parts-firente (forehead), barba (chin or beard), cachete 1 (first cheek), cachete 2 (second cheek). Sometimes the divisions 1, 2 are called ojos (eyes) instead of cachetes (cheeks).

Caracol: (snailshell.) A stone is thrown into the diagram into the different sections in order. The player hops in on one foot and kicks it out. In case of failure, the next boy

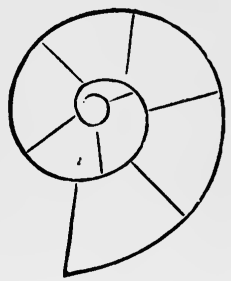

gets his turn. The whole diagram must be made in one play; any failure necessitates beginning at the first (outer) section. 


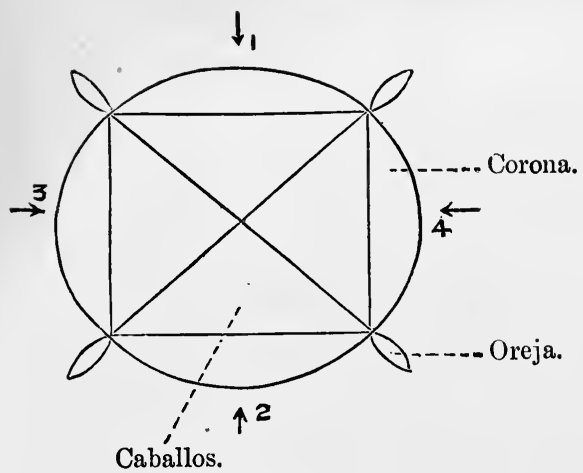

Caballos: (horses.) Simple rounds of the diagram are made, tossing in a stone and kicking it out from each of the four sides in the order of their numbers,

$1,2,3,4$.

5. Los Caballos is performed.

6. La vuelta al MIundo.

When the stone lands in orejas, a play is lost. The beaten boy makes five vueltas al mundo with the victor on his back.

Caballos (2):

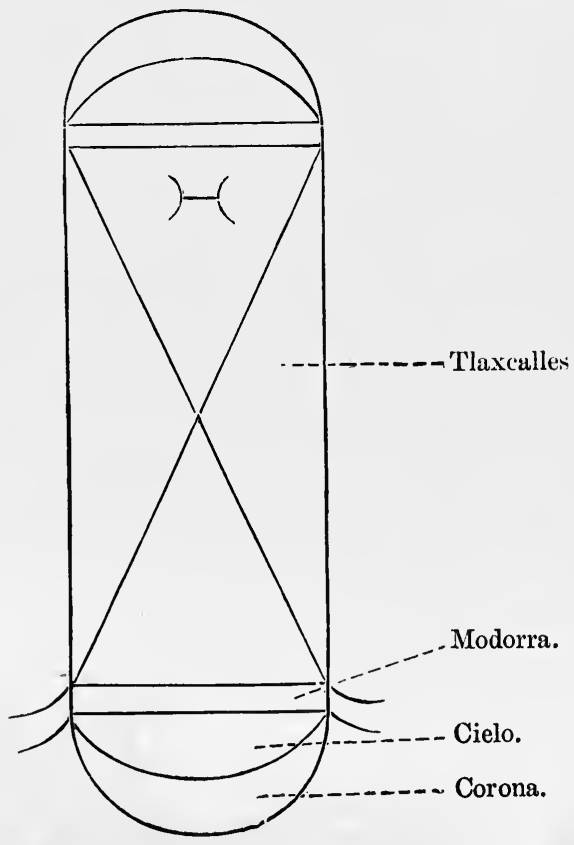


Gigante: (giant.) A truly gigantic and complicated diagram is drawn upon the ground. Many of its parts have specific names.

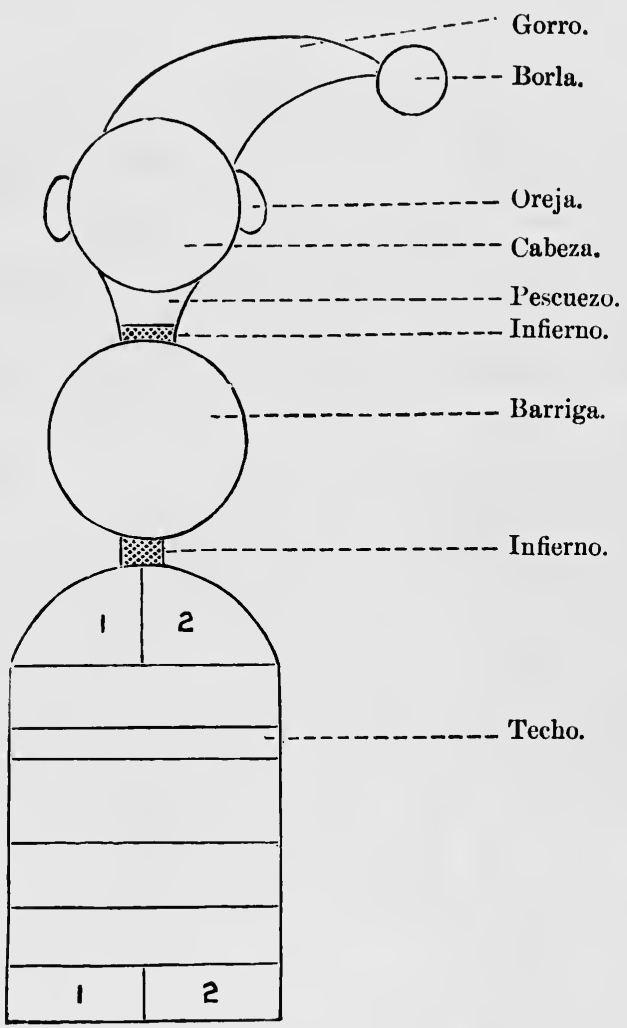

The cajones (spaces)are played in order. The stone is thrown in, the player hops on one foot and kicks it out. Infierno(hell) is not to be played, nor stepped into; the landing of the stone at any time therein, or stepping into it, necessitates beginning anew. In the barriga (belly) one may rest. In it the stone is placed on top of the foot and kicked out. The stone is 
skipped out by the toe into barriga from all the subsequent cajones, but from there is kicked out, being placed on top of the foot. When one loses his play through a failure, he begins at the point of failure in his next turn.

Gigante con cielo abierto: Played in regular order of the cajones. Hop on one foot: no stepping on a line and no stone on a line. Pato is a rest spot. From it the stone is placed

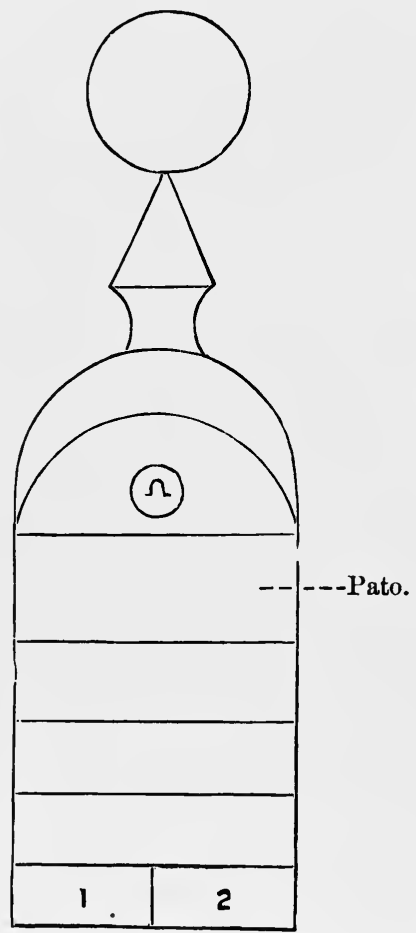

on one foot and kicked in in a single kick. Beyond pato, the stone must first be skipped by the toe-kick into it and then out as above described. 
Gusano: worm.

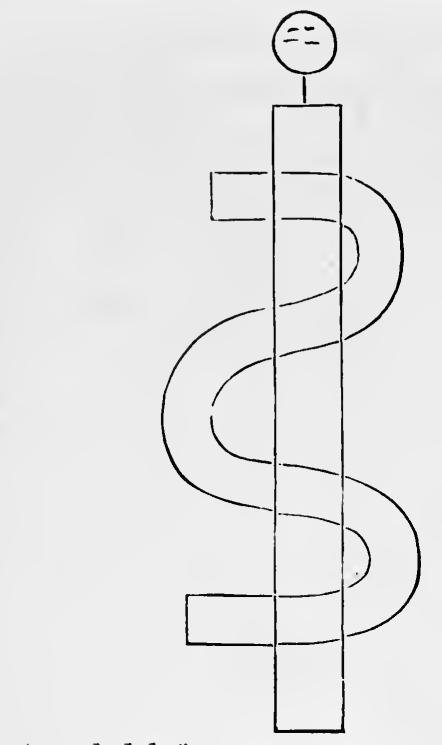

The exact mode of playing Bebe leche, Caballos (2), and Gusano was not noted. All are akin to Caracol and Caballos (1).

Angel del Oro:

Angel del oro

Bendice á su marques

$A$ venido niño

De la portuges

Este no la quiero

Por fea y pelona

Esta me la llevo

Por linda y preciosa

Parece una rosa

Parece un clavel

Acabado de nacer.

Played mostly by girls. They form a ring with hands joined: one stands in the centre. They sing the song, and the central one counts out as they sing. The one on whom the last word falls is out. The last one out becomes catcher in "Tag." 
Donde Tra:

Donde tra canare canurete

Donde tra canarete ra.

They form a circle, and a central one, counting himself, counts out with the above rhyme. The last one out is the catcher. A base or home is then selected. The catcher can catch anyone off the base by simple touching. $\mathrm{He}$ has unlimited time to make the base before he can be caught.

Cebollita: The players sit on the floor, in a line, near together, each between the legs of the one behind: each clasps the waist of the one before. One speaks to the front one in the line and says :

El padre quiere una cebollita.

(The priest wants a little onion.)

Si puede arronque lo.

(All right if he can pull it.)

He must then try to pull the first one up. If successful the onion so pulled is out, and the second is tried, and so on. Failure to pull up anyone gives this one his turn to be puller.

Estira y Afloja: A blanket or other square object is taken and held by the players spaced symmetrically. The leader says :

Quando yo te diga estira, afloja:

Quando yo te diga afloja, estira.

When I tell you pull, loosen :

When I tell you loosen, pull.

They all say :

Estira y afloja

Perdi mi caudal

Estira y afloja

Perdi mi caudal.

Pull and let go-

Give me my property. 
The leader then gives orders, either general or individual the opposite must be done under penalty of forfeit or being put out of the game.

Los Pianitos: All but two stand in a line, with their hands held out in front of them with the backs up. Of the other two, one is seller and one buyer. They say:

Que tiene usted que vende?

What have you for sale?

Unas pianitos.

Some pianos.

Cuanto cuesto?

What do they cost ?

Mil pesos.

A thousand dollars.

Aqui le dijo la mitad del dinero.

Here I give half of the money.

The buyer now says:

Que se tocan muy bien? .

Do they play nicely?

Yo le digo que si.

Yes indeed.

Yo voy á tocar les.

I go to try them.

She moves her fingers over the backs of the outstretched hands as if playing a piano, but with no response. The dealer says:

Que se ponge se solo un anillo de plata y se lave las manos con agua florida.

You must wear a silver ring and wash your hands with florida water. 
The dealer then tries the pianos and they all give out music The buyer says:

Luego tocan: mañana vengo por ellos.

Now they play, to-morrow I come for them.

Another day she comes. The dealer says:

Ahora no hay pianos : hay milpas.

To-day there are no pianos: there are cornfields.

$Y$ estan maduras?

And are they ripe?

Si.

Yes.

$Y$ estan buenas?

And are they good?

Si.

Yes.

The buyer goes from one to another and snaps their teeth with her finger nail. She then pays half the money, promising to return another day. When she comes, there are no cornfields - they have changed into something else. After many strange transformations, each with its questions and replies, the final transformation is into bridges-puentes. The dealer says to the customer:

No hay - hay puentes.

There are no - - : there are bridges:

$Y$ estan buenas $y$ no se caen?

And are they good and don't fall?

Que si estan buenas.

Yes, they are good.

Entonces yo se meto memeto por debajo de los puentes y se caen.

But suppose I go under the bridges and they fall.

Yo le digo que si estan buenos y no se caen quando yo entro.

I tell you they are good and do not fall when I go on them. 
Deje mis zapatos adlentro de los puentes.

I take off my shoes on bridges.

Metese á sacarlos.

Go ahead and take them off.

Whereupon the bridge falls and destroys the purchaser.

La ensalada: (the salad.) All the players sit in a circle. One is Sr. Cura: among the rest one is la muchacha mal criada: the rest are named after the ingreaients of a salad, table-utensils, etc. The Cura begins :

Fui á la huerta y no encontre (azucar).

I was in the garden and found no (sugar).

The one named replies :

Falta usted ci la verdad, Sr. Cura?

Was there indeed none, Señor Cura?

Donde estabas tu?

Where were you?

Yo estaba en. la casa de (lechuga).

I was in the house of (lettuce).

The one named replies:

Mientes tu, yo estaba en la casa de (cuchillo).

You lie: I was in the house of (knife).

The cura now addresses the last one named:

Donde estabas tu?

Where were you?

And so the game goes on. Failure to answer promptily and correctly on the mention of one's name involves a forfeit. The muchacha mal criada is exempt, and answers or not, and irrelevantly, with impunity. 
Venado: (Deer.) The players sit down in a ring on the ground leaving a "door." At the side of each is heaped up a little pile of dirt with a depression at top. These are the drinking places of the deer, and water or spittle is put into them. One boy is "deer." Coming up behind each one in the ring, he strikes two stones together and says :

\section{Cacaon, cacaon,}

at the same time smelling of the head and shoulders. If he makes the boy laugh, he gives him a kick and passes on. When he has gone around the whole ring, he enters through the door and goes from drinking place to drinking place, sniffing at each. Sometimes, though this is reprobated, the players bob his head down into this water. After he has sniffed at all the drinking places, he tries to escape, but they try to keep him in the pen. He breaks out below if he can, when all break the ring and pursue. The boy who catches him becomes deer, but must be carried by the deer on his back to the old ring first.

Maria Blanca: The players form a connected ring: one standing within is Maria Blanca : one outside is Felipon. The players and the one outside carry on a conversation :

Ron, ron, ron.

Quien anda rodeando mi casa?

Who is going around my house?

Felipito Felipon.

Quien es ese viejo tripon?

Who is this old fatty?

Ando á buscar de Maria Blanca.

I am hunting for Maria Blanca.

Maria Blanca esta cubierta

Con pilares de oro y plata. 
Maria Blanca is protected

By pillars of gold and of silver.

Romperemos un pilar.

Para ver á Maria Blanca.

We will break a pillar

To see Maria Blanca.

De que es esta pilar?

Of what is this pillar made?

De papote.

Of grass.

$Y$ este?

And this ?

De oro.

Of gold.

$Y$ este?

And this ?

De plata.

Of silver.

$Y$ este?

And this?

De plomo.

Of lead. \&c., \&c.

As she asks the material she touches the link, where two hands join. She then tries to break through the circle to reach Maria Blanca. This the ring tries to prevent. In case she should succeed, Maria Blanca must run from the circle and then try to get back before Felipon can touch her. The circle readily breaks to allow her to pass, coming and going. At one point in the chain-testing, Maria Blanca must break out.

Prendas: Forfeits are given in many games and must be redeemed. They are held over the head of one player who in answer to the question, decides what shall be done. The 
more common forfeits have specific names and some are quite ingenious. Generally they are to perform some work common in adult life, thus to make and sell tortillas, enchilados, etc. Among common forfeits are :

Que vende nieve. To sell ices.

Que vende tortillas. To sell tortillas. Que vende atolé. To sell atole.

Que vende enchiladas. To sell enchiladas.

Que pido un beso rogado. To beg a kiss.

Que le dan para su boda. Be given something for her wedding Que sirve de espejo. To act as a looking-glass

Santo mocrro. Nose blowing.

Manos postizos. False hands.

Gallos: Two boys play. Each holds up his right foot with his right hand, and by hopping and butting against the other with the knee of his upheld leg, tries to throw him over. The hands may not be used.

Oja de tabaco: Played by boys or girls. The players form a file, each holding on to the one in front. One outside faces the leader of the file and says:

Que dice el Sr. Cura que si manda una oja de tabaco: The priest says to send him a leaf of tobacio. The leader replies: Atras por ella : behind for it.

At these words the catcher runs to touch the last person in the line, who tries to place himself at the head of the line before he is touched. There is much dodging and running connected with this. If the change of place is made safely, the catcher addresses the new head, and again tries to catch the rear person, who again runs to become head. Should the 
catcher touch the other, he takes his place at the head of the line, while the one caught becomes "it."

Anda la rata: Chiefly played by girls. The players sit in a circle, on the floor, with their hands behind them. One with a rebozo in her hand walks behind them and strikes with it anyone who may not have her hands properly placed. As she goes around she repeats :

Anda la rata

Detras de la caja

Anda el raton

Detras del cajon

Anda la gallina

Detras de la cocina

Anda el conejo

Detras del espejo

Anda la ardilla

Detras de la silla

Anda el gallo

Detras del caballo

Anda la vieja

Detras de la reja

Anda la luna

Detras de la tuna.

The mouse runs

Behind the box;

The mouse runs

Behind the chest;

The hen runs

Behind the kitchen;

The rabbit runs

Behind the looking-glass

The squirrel runs

Behind the chair; 
The cock runs

Behind the house;

The old woman runs

Behind the ploughshare;

The moon runs

Behind the cactus.*

At any place she chooses she drops her rebozo behind one of the players. This one, starting up, takes the rebozo and pursues her. They have this dialogue as they run:

Donde fuiste? Where are you going?

Con mi,nanita. With my little one.

Que comistes? What do you eat?

Zopites con miel. Zopites and honey.

Te supieren á bien? How do you like them ?

Como la miel. With honey.

Te supieren a mal? How don't you like them?

Como la sal. With salt.

Anda pero muchacina, sientete in tu lugar. Run girl, seat yourself.

They run three times around, and the one pursued drops into the empty space in the circle.

Pan quemado: The players all form an open line with hands joined. The girl at one end is questioner, the one at the other end is answerer. They say:

Comadre.

Compadre.

Quantos panes hay en la orca.

Veinte un quemados.

Quien les quemo.

El perrito traidor.

Queme lo, queme lo por labrador.

* In the translation the rhyme and jingle are completely lost. 
Comadre! (Term of affectionate address.)

Compadre! (Also, but to a man.)

How many loaves of bread are there?

Twenty-one burned.

Who burned them?

The wretched dog.

Burn him, burn him, for a bad workman.

The last one leading the line then goes under the joined hands of the first and second: when all have followed her, she has been turned around and her arms are crossed; otherwise the line is as at first. The questions and answers are repeated and the line passes between the second and third, thus turning and tying another. Thus they do until all have been turned around and given crossed arms.

El Navio: (=" my ship comes in loaded with__.") The players sit in a circle on the ground. One with a knotted handkerchief throws it to another player saying:

"Hay va un navio cargado de___"

"There goes a ship loaded with___"

This one must reply with a word beginning with the letter mentioned.

San Miguel: All the players but one form a line, each holding the one ahead by the waist. The one at the head is the old woman: the rest are her children. The other is a shoemaker. They all stand. The old woman calls :

Zapatero. Shoemaker!

Que? What?

No te hab̆lé. I did not speak to you.

This is repeated several times.

Finally she says:

Quiero que me haga unos zapatos. I want you to make me some shoes. 
Thereupon he goes about with a stick and draws a line around the foot of each one. As he does so the person says :

Hare que quema! My! it burns.

He replies:

Porqué? Why?

The person answers:

Por la matetena. For the matetena.

When he has measured each he goes away, pretends to make the shoes and then returns. They pretend to put on the shoes. He then says to the old woman:

Pagame. Pay me.

No. No.

Si, me paga. Yes-pay me.

No le pago. I will not pay.

This is kept up for some time. Finally he says:

Te robo un niño. I will steal a child.

No. No.

Si. Yes.

No. No.

Then they try to keep out of his reach, but must not break their hold: the old woman tries to prevent. He may catch anyone whom he can. It is kept up until the old woman has lost all her children.

Al Cansadas: A plain tag: the toucher is free to touch anyone, at any time where they are not on home.

Rueda del Garbanzo: The players form a circle, with one outside. They begin by saying:

$\bar{A}$ rueda del garbanzo

El que se caiga

Es burro manso. 
Ring of peas,

Who falls

Is a gentle burro.

They are circling about at this, and as they go cry out:

$\bar{A}$ que venga la aguililla?

$\bar{A}$ comer su mantequilla.

$\bar{A}$ que venga la guilona?

$\bar{A}$ comer su mantecona.

For what comes the little eagle?

To eat his butter.

For what comes the big dunce?

To eat his sugar-tit.

Meantime the girl outside tries to catch one of those in the ring and drag her out. The rest kick at her, to keep her off. At the mention of the aguililla they squat down and the outside one tries to touch a tardy one. One caught or touched standing when she should squat becomes "it."

Casitas á alquilar: (cf. Puss wants a Corner). All but one of the players select definite points for "houses." As long as they remain touching these they are safe. The one who is out is supposed to be trying to rent a house. She goes in order from one to another saying:

Que no hay casitas á alquilar?

Are there no houses to rent?

Each replies :

En casa de Don Juan Aguilar.

At the house of Don Juan Aguilar.

In case anyone questioned answers anything else (as for example, Si,hay, there are), she is out of the game. While the renter is asking questions, players try to exchange places. 
In case the renter can seize a vacated place the person left without a house becomes renter. Two persons cannot at any one time be on one house.

Mala Conchoncha: Is simply whirling, singly or in couples, vigorously in order to become dizzy.

Alcartaz: All the players but one sit in a circle. She goes around with a cone of paper (alcartaz) point down in her hand and says :

Me compra este alcartaz?

Will you buy this cornucopia?

Que tiene adentro?

What is inside of it?

Ave refran $y$ verso.

Repeat a proverb and a verse.

The player must then offhand name an animal and repeat a verse of poetry. Failure, to do so promptly, requires a forfeit.

Las velas rancius: The players sit in a circle, one of them being leader. The rest all select each the name of a city or country. After these selections are made, they are counted off by twos; these are companions; when any name is called, not that one but her companion must answer. The leader begins :

Tengo site velas muiy ranzias y una se la va ai comer.

I have seven very rancid candles and one is about to be eaten.

At this she mentions one of the player's names. The companion of the one named replies:

No se va de comer.

It is not about to be eaten.

$S i$, va de comer-

Yes, —is going to be eaten. 
And she names another. If the person named answers, or if her companion fails to answer, a forfeit is demanded and the player in fault drops out. When this last occurs, constant readjustment of partners is of course necessary.

Juan Pirolero: All sit in a circle: one being the leader All but the leader select a trade :-washerwoman, tortillamaker, dressmaker, grinder, etc., etc. The leader is a fluteplayer. Throughout the game a little song is sung:

\author{
Este es el juego \\ De Juan Pirolero. \\ Que cada cual \\ Atiende a su juego. \\ This is the game \\ Of Juan Pirolero. \\ Let everyone \\ Attend to his play.
}

While the song is kept up, each of the players in pantomine exhibits her trade, and the leader by gestures appears to play a flute. At times she changes and mimics the motions proper to one of the other players. This one must at once, under penalty of forfeit, take to fluting, changing instantly to her own performance when the leader again changes. The game requires close attention.

Vibora (snake): All the players but two form in file, with hands on the shoulders of the one in front. The tallest is in front and the rest decrease in height backward. Two form a bridge, with joined upraised hands. The vibora twists its way through under this bridge, but the last one is caught by its descent. She may try to escape capture by ducking, but rarely succeeds. The names of two fruits are whispered in her ear: one of these she chooses, and then lines up behind the leader to whom it 
belongs. While the vibora marches around or under the bridge all sing :

A la vibora, vibora, ve la mar
Por aqui deve pasar
Una nina, niña, cual sera
La adelante corre mucho
La detraz si quedera.

The game is kept up until all have been caught by the descending bridge and have taken places behind the two leaders. The two sides then pull against each other, each trying to drag the other or its separated leader across a given mark.

Cedazo: (sieve.) The players stand in line, one behind the other. The catcher stands in front of this facing and says :

Me vende Ud. un cedazo.

Sell me a sieve.

Atras por el.

Go back for it,

replies the one addressed, and dodging out runs to the rear of the line. The catcher may run down on either side trying to catch the pursued before he is located. The game is kept up until all are caught.

Gato y raton: (cat and rat.) Boys form a ring with joined hands. One called a rat stands within the ring, another called a cat stands without. The cat tries to catch the rat, while those forming the ring try to prevent. The rat may run outside the ring and the cat may run in, but for the former the ring readily breaks, while for the latter it, does not.

Los Listones: (ribbons.) All but three players sit down 
in a row. Of these three, one is the maestro (master), one diablo (devil), and one angel (angel). The maestro secretly assigns colour-names to all the rest, who are listones (ribbons). The angel and devil then take turns in addressing the maestro.

Angel :

Tan, tan. Rap, rap.

Quien es? Who is it?

El angel con su cruz. The angel with his cross.

Que quiere? What is wanted?

Un liston. A ribbon.

De que color? Of what colour?

Verde. Green (or some other colour).

Quien es verde? Who is green?

If there is a liston of the color selected he becomes the angel's partisan; if there is none, the angel has thrown away one chance. Then the devil speaks:

\section{Diablo :}

Tan, tan. Rap, rap.

Quien es? Who is it:

El diablo con su hacha. The devil with his hatchet.

Que quiere? What is wanted?

Un liston. A ribbon.

De que color? Of what color? Etc., etc.

When all the players belong to one side or the other, they . form two parties, which pull against each other.

El gran Chino: (the grand Chinaman.) One player sits in a chair, while the rest form a circle squat on the floor. Each takes the name of a country or a town, announcing it that all may hear. The one in the chair knots a handkerchief into a ball and says: 


\section{Yo soy el gran Chino de Valencia, Que tiene la gran ocurrencia \\ De entrar en la ciudad-}

I am the grand Chinaman of Valencia, Who has the great idea Of entering the city-

Naming one of the cities or lands, he throws the handkerchief to the person bearing that name. This one at once responds :

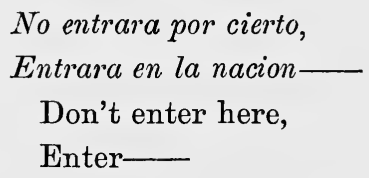

throwing the handkerchief at once to the one named. To forget the name of the one to whom one throws counts as a loss. Three losses put a player out of the game. When all players are out, forfeits are redeemed. A favourite forfeit in this game is manos postizos (see Prendas: Forfeits).

Pipicigañas: As many boys play as like. They sit on the ground in a close circle, with the hands, palm down, on the ground and close together. One player goes around saying the rhyme:

\section{Pipicigañas \\ Come las gañas, Come las tu que \\ Las tienes tamañas.}

At each word he pinches the back of the hand of one player, taking the hands in order. The person upon whose hand the last word and pinch falls puts that unfortunate member out of sight under his jacket and keeps it there. When both hands of each player have been thus encaged, the game ends. 
Colorines : Colorines are little red beans, like seeds, borne in pods on a tree. They are used as shooters in several games. The most simple is commonly called colorines, but so are some other games. A shallow pit is dug; a set line is drawn at some distance away. Players toe this line and try in turn to shoot a colorin into the hole. The first to succeed takes all those lying on the ground and shot by unsuccessful predecessors.

Alguaciles $=$ Los Alcaldes $y$ los Ladrones : The boys who play are divided into ladrones (robbers) and alguaciles (officers). To determine this, a small stone is taken in the hand and secretly transferred, back and forth, between the hands: the two hands, clenched, are then displayed and one is touched by another player: if the hand containing a stone is touched, the player becomes a robber; otherwise an alguacil. Certain spaces are marked out as cuevas (caves) within which the robbers are safe. The business is for the officers to catch the robbers as they run from cave to cave. Policeman and robber at once exchange parts on occasion of a capture. If two officers take part in a capture only the first to touch the prisoner becomes a robber.

Locomotora: locomotive. All the boys form a line, each taking firm hold of the bottom of the jacket of the one before him. The whole line then tries to switch off the end ones by vigorous movement. If-as indeed is more commonly the case-the boys wear no jackets, they take hold of the faja or girdle of those ahead, taking hold firmly on each side.

Jicote: As many play as choose. A bouncing ball is used. It is kept bouncing by all the players, who strike it down with the palm of their hands. In case a player nearest the ball fails to strike it, or in case one is struck by it, he must stand up against a wall with his hand spread out against it; all in turn throw the ball at his hand, trying to hit it. When all have thrown, the game is renewed. 
Escondidos: There are here several seekers and several who hide. The parties are decided as in alguaciles. The seekers blind while the rest hide: when these cry "ya" (ready) the hunt begins. When all those hidden have been found, the sides exchange.

Burro castigado: There are a number of games more or less like our leap-frog. Several of these go under a general name of burro or donkey. Among these burro castigado appears to be at once the most complicated and the most in favour. To determine the burro, all jump from a line: the least jump makes the burro. He bends over sidewise and the players then jump in turn over him. There are fifteen different jumps in the game, the order of which is fixed by the following doggerel :

Primero, sin tocar en ello.

Segundo, senton sin consideracion.

Tercera, con su rodiera.

Quarto, bien sentado y mal acostado.

Quinto, me monto en un chivo pinto.

Sexto, chupate esto.

Siete, un medio para tu billete.

Ocho, para tu biscocho.

Nueve, nevar quiere.

Diez, nevado es.

Once, repique el conde.

Doce, repique doble.

Trece, el rabo te crese.

Quatorze, la vieja tose.

Quince, el diablo le trinche, con tu respectivo trinche.

These jumps are as follows:

1. Simple jump in any fashion.

2. Jump and bump (or not). 
3. Kneel on back with one knee.

4. Kneel and recline on one arm.

5. Jump up astride without hands.

6. Jump clearly over and slap him behind.

7. Jump over, not touch with hand and kick with right foot.

8. Kick and slap as you go over.

9. Come down hard with callous of hands.

10. The same.

11. The left hand flat on back : strike with right fist.

12. Strike with both fists.

13. Slap bottom with right hand.

14. Cough as you go over.

15. Prick and fall heavily with finger tips.

When the last one has made his final jump, all run, and the exasperated donkey chases them. This is sometimes also called burro castigado veracruzano.

Burro corrido: As many play as choose. They bend down in line. The hind one leaps the whole line in order and then bends down in front of the rest. So the action is kept up continuously.

Olla de tamales: Equal sides are chosen. The outs are decided with a small stone. The out-side then gives a back, in line: all are bent and the head of each boy then rests against the side of the preceding one. The boys of the other side must then vault up on to this line of backs. When all of one side have successfully mounted the other, they exchange.

Maruja: A ring is made on the ground, and a stick or club is set up in the centre. To determine who shall play first, they throw stones: he who throws further plays. They have agreed beforehand upon a score to be made. The player tries to strike the stick with his stone, and knock it as far from its position as he can. He counts the number 
of his own foot-lengths that it falls outside the circle. If both players fail, they determine the choice of play by again throwing stones: so also after every count, When the score agreed has been played, two stones are placed with a stick across them. The winner places his foot under the stick ready for a kick.

The loser asks :

Que quiere la maruja?

What does Molly want?

The winner answers:

Que me vaya á traer este cuerno hasta el Puente de Toluca. That you carry this horn for me to Toluca Bridge,

and kicks it as far as he can. The loser has to chase it, bring it back, and replace it on the stones. Meantime, the winner runs backward as far as possible. Then the loser pursues until he overtakes him, and must then carry him on his back, to the spot.

Chota: A small hole is dug in the road near the curbstone. Two lines are then marked, one near, the other distant. The players - two or more-are supplied with dry beans : each puts an agreed number of pairs of beans into the hole. Each pitches a bean from the distant line toward the hole: who gets nearest has the first play. He tries to shoot his bean from its position into the hole. The order of success decides the order of playing. The first player then takes all the beans from the hole, stands at the near line, and tries to throw all at once into the hole. So many as go in are his. The next player tries with the balance, and so on, until all are won. When a player has once got out as many as he put in, he may cry as he throws"saca de un non" or "saca de un par"-and takes all if he succeed in putting one or two in. This game is often played 
on paved streets : when a bean falls between paving stones it may be put on to the nearest stone to fix position from which to shoot. The player may also shoot from his hand placed above the bad spot.

Tope: Played with large flat beans, each player having one. These are flipped carelessly, so as not to fall too near others. The first player then shoots his, so as to try to hit another. If he succeed, he takes the one hit and has another shot. If he fail, the next player takes a turn.

Pan y Queso: This is our "Puss in the Corner." Corners are selected, one less in number than the players. The one left out addresses another saying:

"Donde venden pan y queso?"

"Where do they sell bread and cheese?"

He replies pointing to others who are exchanging corners :

Alli lo venden rico y tieso.

There they sell it rich and strong.

Otherwise it is exactly like our own game.

Luchas: A simple test of strength in pushing or twisting. There are several methods: $(a)$ Lines at suitable distances are drawn and the contestants take their places: each places his hands against those of his opponent, palm to palm, with arms held horizontally. Straight pushing ensues to dislodge the opponent from his position without quitting one's own. Standing as before, the opponents join similar hands-either right or left as agreed. When firmly clasped each tries to turn or twist the other's hand. (c) At a table: with elbows on table and immovable, with arms at an angle of forty-five degrees the opponents join hands. A push tests relative strength.

Carreras: (races.) The most popular appears to be the ordinary three-legged race. 
La Ronda: Two boys stand holding the ends of a rope of some length. Other boys drive dogs toward and between these two, who by a sudden tightening of the rope throw the animals into the air.

Ojita de agua: A round pit is made with the bent fingers and thumb of one hand. Another is invited to thrust his finger into this to find water. $\mathrm{He}$ is pinched with the other hand, held at bottom of the pit.

Ocho Mexicano: A diagram like the following is drawn upon the ground:

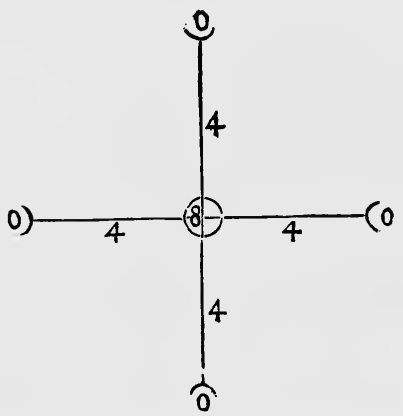

the central circle is but little larger than the ordinary centavo, or copper coin. A line is drawn at some distance where the players stand and from which they toss their pennies. The plan is to toss into the central ring or to dislodge a player already in a position where he can make a count. Landing in the central ring counts eight at once and ends the game Landing upon divergent rays counts four. Landing on the spaces marked at the end of the rays counts zero. Either two players or four, playing on two sides, take part.

This brief sketch of children's games is very incomplete. Some of the commonest games were not observed with care. A list of other games not noted is here given.

Circo: circus in which various acrobatic figures were made, 
as rapor (steamboat), araña (spider), and locomotora (locomotive).

Picale.

Pitima.

Gusano: see diagram.

Obliga.

Quebrantes huesos.

Zopilote.

Gallina con pollos.

Roña.

Compadres calabaciados.

Chinalita de oro.

Les tres naranjas.

Rayuela.

Burro Mexicano.

Pelota: ball, several games.

Canicas : marbles, various, as

maté.

trienta y una.

maté tena.

Trompos : tops, various, as

avançadas.

secos cocheros.

Counting-out Rhymes:

To find which child has been naughty or is to blame for some mishap, boys have some counting out rhymes. Thus:-

De una, de dola,

de tela, canela,

sumbaca, tabaca

de vira, viron;

cuenta las bien

que las once son.

'This is apparently meaningless, although the last lines may 
be translated-“ Count them well, there are eleven," Another one runs :

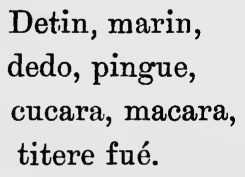

Which also appears meaningless, but is, when properly pronounced, marked by an excellent swing.

To determine an unknown offender in a party, one boy stands and places the rest in a circle about him for an ordeal. If any boy declines to take his place in the circle it is plain that he is guilty. When all are arranged the leader spits into his opened hand, and then slaps down two fingers into the saliva. He, toward whom the struck saliva flies, is the offender.

On coming out frum school, one boy may say to another, "What kind of fruit do you like to eat?" On his reply being given, the questioner catches hold of a hair and pulls it out, blows it up into the air and cries, "Bring — a cartload of —_," mentioning the fruit named. Some claim that this is true child-magic, others that it is simply an excuse for pulling out the hair.

Boys in school will ask one another if they want a little louse (piojito); and if the one asked, in ignorance or otherwise, replies "yes," they proceed to raise a sore place on the hand by gently rubbing the moist finger tip back and forth over a small space on the back of the hand.

\section{Indoor Sports: General.}

176. Playing Cards: Baraja.

Small, for children. The set consists of forty cards in four suits-oro (money), copa (cup), basto (club), espada (sword). Each suite contains ten cards, seven numbered and three with 
pictures. The picture cards are rey, caballo, sota-king, knight, and knave. The ace usually is surrounded with fancy designs: the two spot has a central fancy figure: the four spot has a design between the pairs: and the five spot has decoration in the available spaces.

177. Playing Cards: Baraja.

Small for children. Whole set printed on one card to be cut. This is a common way of selling cheap sets.

\section{Tarjetas del Diablo : Devil's Cards.}

Seven cards each with three columns of numbers less than 127 so arranged as to determine a person's age or a number chosen. One player points to the cards containing the number he has chosen: the other, by adding the first numbers on these, announces the result as the chosen number.

179. Oraculo de la Fortuna: Fortune's Oracle.

The players form a pool, each contributing two counters. The diagram gives responses under the heads-religion, agriculture, profession, innocence, medicine, sea, astronomy, musie, liberty, matrimony, burial. Dice are thrown, each player throwing twice: the first throw determines in which topic the question shall be chosen: the second determines which of the printed responses in that topic he has. A person throwing "doubles" takes the whole pool: non-throwing of doubles requires contribution of one counter to the pool.

\section{Loteria de Figuras : Picture loto.}

The crier holds a pack of little cards, each of which bears a picture. Similar pictures, twenty-five in number, are variously arranged upon twenty-four larger cards-each containing the full series. The crier runs through his pack, calling the 
pictures as they come. Each of the other players holds one of the large cards and covers the pictures thereon as they are called, with counters. When five pictures in a line-vertical, horizontal or diagonal-are covered, the player holding that card calls out and receives a reward.

\section{Cascabelito mudo : the Silent Bell.}

The outfit consists of a printed list of forfeits (twelve for each sex), dice, and five small brass bells, one of which contains no ball. The leader goes from player to player: he puts the four sounding bells into a handkerchief. Conversing, he shows the silent bell to a player, then puts it with the rest, conceals, and then displays all. If the player points out the silent bell, well: otherwise he pays a forfeit. The leader passes to the next player, with the same performance. He goes thus three times around the company. Forfeits are redeemed by penalties determined from the list by dice.

\section{Indoor Sports: Board Games.}

182. El Laberinto : the Labyrinth.

The diagram bears a picture of a much-twisted serpent whose body is divided into sixty-four spaces, each numbered and bearing a picture. A last space is unnumbered and bears the picture of death. Three dice are used to determine plays. If, in entering, a player throws three ones, he has gained the game. Otherwise, he plays through the series to No. 63 marked with blind Fortune's picture. If one should pass beyond to death, he is out of the game, unless thrown back by some other player. A first throw of three fives takes the piece to 42 . In the spot of the bull, the player takes one counter from the pool: in the rooster, two: in rooster No. 51, three. Upon any one of the spots occupied by a laying hen he places a counter in the pool and loses a turn. On a spot with a running rabbit 
he makes a second count of his throw. Upon the dog or the camel he stops until another player lands thereon and takes his place. On arriving at an occupied space he throws back the occupant to his previous position. If afraid of going beyond 63 , to death, he may stop on 61 or 59 , lose a turn, and pay a counter. If the other players pass and reach death, the game is his if he is nearest 63. Should he however be thrown back after taking this position, he may take his turn and not pay his counter.

182a. Juego de la Oca: Game of Fate.

Simpler arrangement of diagram, but with same number of spaces, and with similar ideas in the rules for movement and counting.

183. Juego de Ferro-carril urbano: Game of Street Car.

The diagram represents a double street car line, the tracks being distinguished by colours-red and green. These are divided into numbered spaces from 1 to 62 . Two sets of players equally divided. One set go in one direction upon the green track, the other in the opposite direction upon the red. Dice determine order of playing and the moves. Certain points bearing special names-driver, conductor, mule-head, bridge, doubtful right of way, car off track, change cars, change mules-give advantage or disadvantage, according to set rules. Reaching space 63 finishes the game for any player. The first side " out" gains.

184. Corrida de Toros: Bull-fight.

The diagram bears thirty-two spaces, numbered and leading to the central picture of a bull-fight. The spaces bear scenes from a fight; and there is the usual range of advantages and disadvantages, due to landing upon one or another space. 
185. Juegu del Circo: Game of Circus.

The diagram represents twelve circus performances. Two dice are used to determine movements of pieces. A pool is made of counters, each player contributing. Rules connect gains or losses, in counters, with the movements of the players' pieces.

\section{Carreras de Caballos: Horse Races.}

The course laid out on the diagram is divided into spaces numbered from 1 to 74. Eight spaces are marked corre (run): four are posta (post): three together, numbers 37, 38, 39, are resumidero, where a river is represented. 36 and 40 are the river banks. Dice determine who shall play first: three dice are thrown, and the highest throw gives the play. In throwing for the entering play, one die only is used: for subsequent plays, three. A pool is formed at the beginning by equal contribution of counters by all the players. Landing on an occupie ù point throws the occupant back to a posta: but gives him a counter from the pool. Landing on corre advances the player the number of spaces that brought him there. Landing in posta loses the player a turn and costs him two counters. Pieces in posta are, however, secure against being thrown back. Landing on No. 36 necessitates paying ten counters for crossing the river. Falling into resumidero, a player is delayed until some other lands on 36 or 40 : he is then released, takes two counters, and his rescuer must take his place in the river. The first to reach the last posta has another play and takes three counters. Playing from the last corre without just the throw necessary to take him out (namely, three), the player begins the whole game anew. A player thrown back from the spot on which his first throw placed him, not only begins anew, but pays four counters to the pool. 
187. Nuevo Juego de la Solitaria: New Game of Solitaire.

The old game of solitaire, where a series of pieces are arranged upon a symmetrical diagram, somewhat cruciform, with a central space left empty. The pieces jump each other as in checkers or draughts, until but one piece is left. The diagram varies slightly from the familiar form.

188. Juego del Coyote: Game of Coyote or "Wolf."

Fox and geese, but the coyote or little wolf replaces our fox, and hens replace the geese. There are thirteen fowls, one wolf.

189. El Nuevo Coyote: the New Coyote.

A variant upon the last. The diagram is entirely different in form. Four wells occur in it, falling into which entails loss on player. Twelve fowls and one coyote are used.

190. Castillo de los Aztecas : the Aztec Castle.

The diagram represents a truncated pyramid divided into squares-eight on the lower line, seven on the next, six on the next, five on the next, and four at top. On the lower three lines of squares are ranged twenty-one assailants. Above the pyramid is a rectangle with eight spots in three horizontal lines. Upon it are placed three defenders. The two upper lines of squares in the pyramid are unoccupied. The defenders are to be hemmed in so as not to be able to move. They cannot be taken but may take the assailants. The defenders may not however move out of their rectangular area.

191. Sitio de Sebastopol: Siege of Sevastopol.

In character similar to two preceding. Nine spaces for the besieged, and different form of diagram. There are twentyfour assailants and two defenders. 
192. 2o de Abril : Second of April.

This "military game" bears the name of a date famous in Mexico for a glorious victory. It is a game of siege, in general plan like the three preceding. The diagram presents sixtyfour spots arranged around a central "plaza," which has five spots marked with stars. There are forty-five assailants and five defenders. Of the former, forty are soldiers, four are division leaders, one is general. When the five star-marked points are occupied by assailants, the game ends. An appalling. mass of rules is arranged, to make the game "less exacting than chess but more exciting than draughts, Aztec Castle, Sebastopol, \&c., \&c."

193. La Batalla: the Battle.

Each of the two players has twenty pieces,-a flag, general, two artillerymen, two mortarmen, two cavalrymen, twelve foot-soldiers. These are placed in set order upon a special diagram. Special moves are arranged for each piece, though on the whole the action is somewhat similar to that in draughts. The loss of the bandera (flag) on one side concludes the game.

194. La Guerra de los Kickupoos : the Kickapoo War.

There are two players. The game is in two parts. The board is diagrammed into eight lines of eight squares. Each player has sixteen common men and two commanders. The former are arranged upon the lines nearest the player: the latter upon the third or fourth lines. The commanders can go one point in any direction, cannot be taken, can and must take opponent's common men as in draughts whenever possible, but cannot move outside of their territory-the four centre lines of squares. The common men may go forward, right, left, or diagonally along marked lines, but not backward. When a 
common man reaches the opponent's " king-row," he cannot be taken. Whoever succeeds in putting all of his surviving men into the hostile camp first wins.

195. Oca General Porfirio Diaz: Fortune of General Porfirio Diaz.

At the centre of the diagram is a portrait of General Diaz : around it are arranged one hundred pictures of incidents, places, or persons figuring in his career. Three dice are used: one small four-sided pyramid and two dodecahedra. The former bears the arithmetical symbols $+-x \div$ and indicate the operation to be performed with the numbers given by the other two. Moves are made in accordance with the throws. Falling upon a war or pronunciamento advances the player: landing on specific points is unlucky: certain gains on the part of one player involve losses to others.

196. Los Insurgentes: the Insurgents.

Three persons participate: one, the narrator, reads the occurrences taking place at the different points reached by the players. Dice determine the movement of pieces which follow along the lines followed by historical leaders of insurrections. This painfully instructive game in Mexican history is the invention of the eminent geographer and historian, Antonio Garcia y Cubas.

197. Los viajeros en Mexico: Travellers in Mexico.

This geographical game is by the same eminent author as the last. An excellent map of Mexico with railroad, high road and water-lines of travel marked upon it forms the diagram. Two different journeys are marked out, one for each player. A pool is formed. Plays are determined by dice. The player must give data regarding the places wher 
his piece rests, or lose counts. In passing rivers, a fee is paid for ferriage. At certain prison-points a play is lost, etc.

198. Los Exploradores del Polo: Polar Explorers.

A good map of Arctic regions forms the diagram. Two or more players may take part. Two itineraries are mapped out, in blue and red lines. At starting out, five dice are thrown, but on passing each $5^{\circ}$ line of latitude one is dropped. Of course, the first to reach the Pole wins. Upon making his play, each player must give name and geographical position of the spot on which he lands. Failure to do so requires payment of one counter to the pool. Landing upon a spot at the beginning of a sea-current, or in the line of a hurricane, requires the following to the end of its course and payment of counters. Forgetting the proper number of dice on crossing a $5^{\circ}$ parallel requires payment to pool. Certain fortunate spots give the occupant rewards.

199. El Cambio del Ministro: Change of the Ministry.

Seven figures in colors representing persons notably different in feature, form and dress are printed on a paper. These are all cut, by lines alike in all as regards position, into seven pieces each. By the rearrangement of these pieces a great variety of comical transformations may be made.

200. Siluetas: Silhouettes.

A sheet of patterns for making finger-shadows of faces, animals, birds, etc.

Of all these table games the really popular and standard are probably numbers $176,177,180,182,182 \mathrm{~A}, 187,188,190$, 191. 


\section{POPULAR CELEBRATIONS.}

Jan. 6th: Day of the T'hree Kings is generally celebrated. The three kings are believed to represent three races, one being a Caucasian, one a Negro, and the other a Mongolian. In the Valley of Mexico, in many families the day is observed by giving gifts to children. At Morelia boys dressed, painted and bearded, to represent the three kings, go to a church where are figures of Mary, Joseph and the child, carrying gifts. A special service of prayer and song is held in the church in connection with this. Figures of the three kings are sold everywhere on this day.

201-203. The Three Kings: figures in clay. Guadalajara. (See also Nos. 292, 293.)

Feb.: Carnival. Celebrated generally. Masking and rough play take place on the street. Cascarones are used almost everywhere, although there are local differences in form and character.

At Morelia, groups of dancers go through the streets with music. The masks used are hideous. One person in each company plays the part of a woman, but wears an enormous man's hat. One of the party carries a light framework covered with canvas, which in form and colour represents a bull. This is carried so as to conceal his head and upper body, and he plunges and acts the part of a toro. These parties stroll, during the day, through the streets, stopping and causing fun in front of houses: at night they meet at some central place and parade with all sorts of antics through the main promenade. Everywhere during the day cascarones are broken. These are made of empty eggshells, colored or gilded; into them are put bits of cut paper, ashes or eau-de-Cologne. Sometimes candies are mixed with the paper bits. These 
cascarones are broken over the heads of women and children; the bits of colored papers entangled in the hair are a great nuisance. After a day of carnival the streets are so filled with them that a special sweeping is necessary.

In Zacatecas, the dancers are young men from the best families. They are dressed in black, and act the part of Spanish students. The bands go together to the promenade, where they open the carnival. All wear great cavalier hats, each with a large wooden spoon fastened at its side. There is good music, and the parties, separating, go from house to house serenading and dancing. The cascarones of Zacatecas are unusually pretty.

\section{CASGARONES, MASKS, \&c. :}

204-207. Cascarones: of commonest kind, made of hens' eggshells. Guadalajara.

Eggshells are laid by through the whole year for use at carnival-time. Women bring great baskets of these eggshells to market, and sit in the market place colouring them. The colours are mixed in small saucers, and are applied with rags or with the finger tips. In the latter case, a different finger is used for applying each colour : the egg being held in the right hand, the fingers of the left hand are dipped into the colours and smeared or patted against the eggshell. The contents of these cascarones vary. Most commonly they are square bits of bright colored paper; these are called amores or gasajo. To them may be added candies, colacion. They may also contain ashes or perfume. These contain only amores.

208-228. Cascarones with amores and colacion: Guadalajara.

229. Cascaron with amores: made of turkey's egg. Guadalajara. 


\section{0-235. Cascarones with amores and colacion: Guadalajara.}

Sometimes these cascarones are covered with bright paper or foil mounted on sticks, and surmounted by figures of wax. Other pretty methods of decoration are practised. The cost of these elaborate cascarones is considerable, and they are given to friends as presents or souvenirs.

236-238. Cascarones: flowers made of eggshells wrapped with tinfoil and surrounded with a corolla of bright tissue paper petals and a calyx of green paper sepals. City of Mexico.

239-242. Cascarones: ornamented. Eggshells wrapped with tinfoil, surrounded by wreaths or supplied with trophies made of the national flag. City of Mexico.

243-245. Cascarones: comic. Eggshells covered with wax, representing faces of old women. These are fringed and bonneted with tissue-paper. Puebla.

Still more elaborate designs are made by the use of sprays of artificial flowers, or moss, and figures of wax.

246. Cascaron: ornamented. The eggshell, painted pink, is surmounted by a paper dove and surrounded by sprays of artificial flowers. Paper streamers bear the words $U n$ recuerdo de carnaval: a souvenir of carnival.

247. Cascaron: comic. The eggshell forms the body of a fat soldier, who is dressed in white with black markings. He carries a horn, gun, and knapsack. City of Mexico.

248. Cascaron: fancy. Female figure holding a mask in her hands. This represents a bull's head. By pulling a string it is put over the woman's face. City of Mexico.

249. Cascaron: fancy. Surmounted by a pretty wax figure of a bull-fighter with a silk capa. City of Mexico.

250. Cascaron: fancy. Careful and delicate piece of 


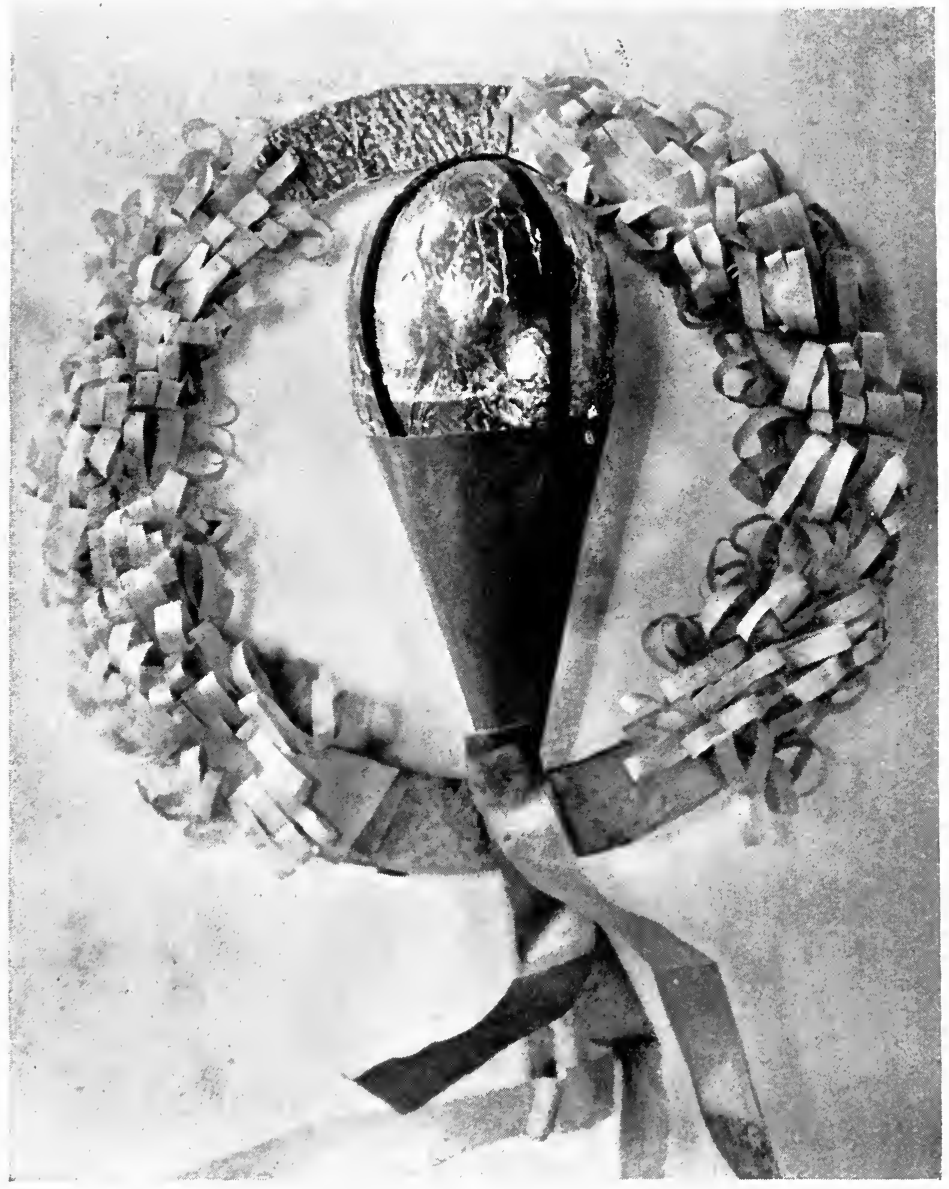

FIG. 7.-CASCARON: CITY OF MEXICO. (NNo. 240.) 



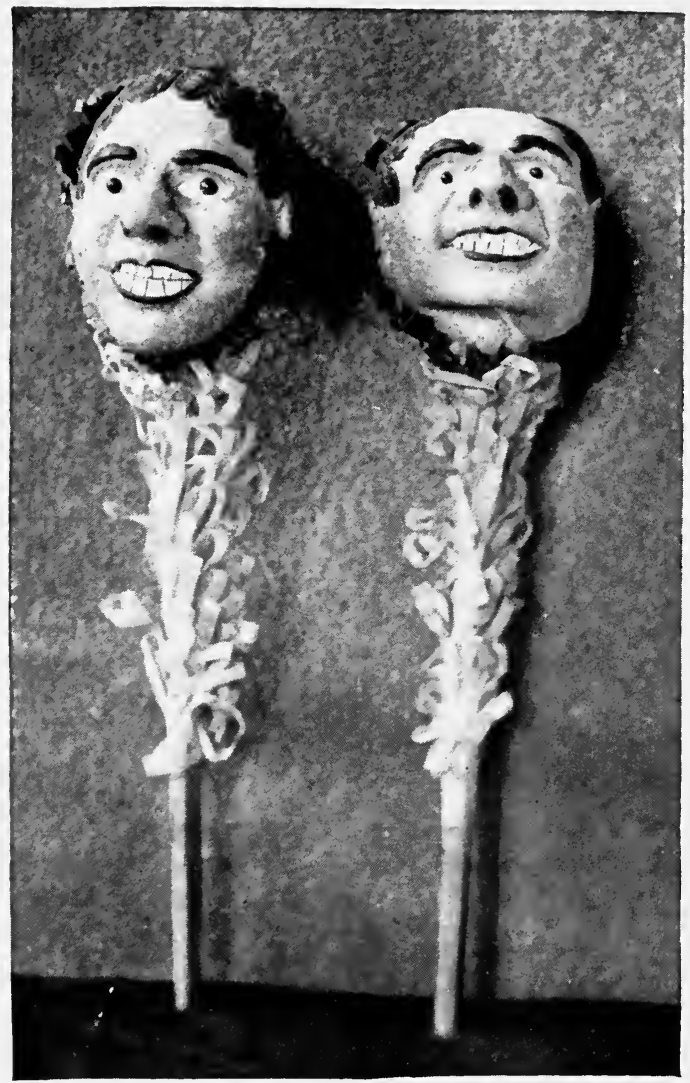

FIG. 8.-CASCARONES: PUEBLA. (Nos. 243-245.) 



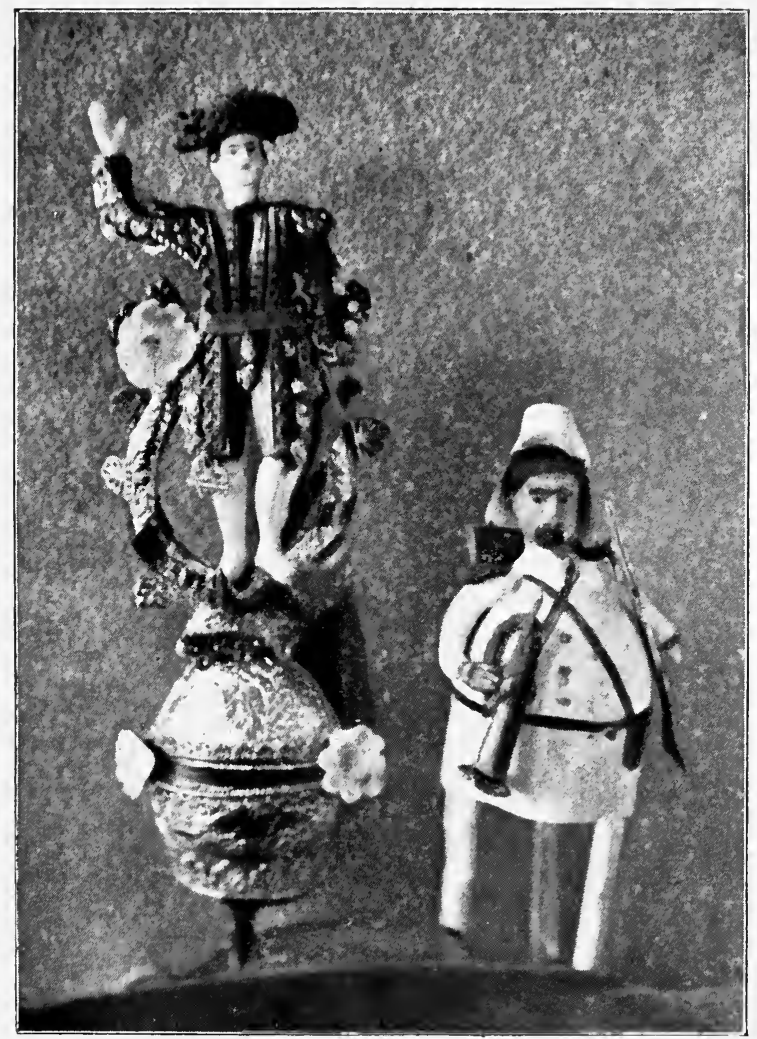

FIG. 9.-CASCARONES: CITY OF MEXICO. (Nos. 247, 249.) 

work. The eggshell is tinfoiled; over it rises a lyre covered with tinfoil, which rests upon a bull's head; above the lyre is a bull-fighter. Flowers of wax are at the sides. City of Mexico.

250a. Cascaron: fancy. Surmounted by a wax figure of a dancing girl dressed in silk. City of Mexico.

251. Mascara: mask. Cheap, made of card. City of Mexico.

252. Mascara: mask. Card. City of Mexico.

253-254. Mascaras: paper masks. Guadalajara.

255. Cucuruchos : fools' caps. Worn at Carnival. Cholula.

Holy Week: The celebrations connected with Holy Week and a few days preceding it cannot here even be enumerated. Only those directly related to the specimens can be mentioned. The Friday preceding Palm Sunday, Viernes de Dolores, is a day of floral decoration. In the churches the altars are adorned, chiefly with offerings brought in by the common folk. Along the streets women display their little stocks of decorations. These consist of small glass balls, filled with water of a brilliant red or yellow : balls of clay, painted red, bear a brush of yellow bristles a-top that make them look like flowers with many projecting stamens: small flower-pots are sold that bristle with similar yellow stamens: also small artificial pine-trees in pairs. In other places, at street-corners are squatted busy wörkers who have brought in great bunches of cycas-fronds and of palms. The cycas-fronds are sold in their natural condition, but the palms are split into long strips and woven into fancy forms-stars, wreaths, etc. Of the basal scales quaint artificial flowers are woven. All of these are sold for small prices and are put up in churches or homes. At night in almost every house, altars, of more or less elaborateness, are built up of these various elements, and lighted with candles. 
621. Balls with yellow bristles: Puebla.

622. Pair of flower-pots :

623. Pair of artificial trees.

624. Flower of Palm-bracts.

625. Star of braided palm.

The following day and on Palm Sunday the same venders plait palms into beautiful braids to be carried to the church for blessing. (See 584 to 589.)

\section{MATRACAS :}

Matracas begin to be sold about Palm Sunday and their sale continues almost all of Holy Week. These are rattles where a cogged wheel is made to strike against a narrow projecting strip by whirling, in such a way as to produce a loud rattling sound. Their proper time is from Thursday to Saturday. On Thursday the church bells cease ringing, and all day Friday they are silent. "The spirits of the bells have gone to Rome." They come back on Saturday_-"the Saturday of Glory." During their silence, in the church towers great matracas take their place. The smaller matracas are sold by thousands in the streets. The cheapest are made of wood, and cost a farthing. Large wooden ones are a foot and a half, or more, in length. Very common are those of tin, and the revolving parts of these are made heavy by the attachment of some fancy figure of tin brightly painted. The body remaining of tin, these figures may be of plaster and gaily gilded or foiled. More expensive matracas are made of bone. These represent considerable work, and a variety of fancy objects is attached to them for weights: these are of bone, pottery, glass or other material. Most expensive of all are pretty matracas made of silver. Weighting these are figures of silver representing bull-fights, tlachiqueros, aguadores, or pretty composi- 



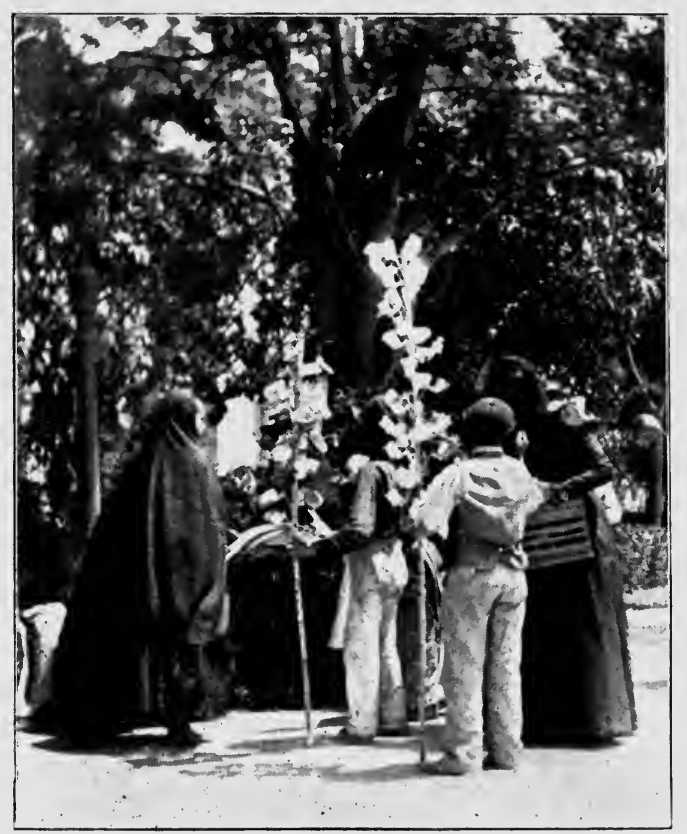

FIG. 10.-SELLER OF MATRACAS: CITY OF MEXICO. (Nos. 256-272.) 
tions of silver filigree. During Holy Week matracas are heard everywhere on the streets.

256. Matraca, wood: cheapest grade. Puebla.

257. Matraca, tin : bucket. Puebla.

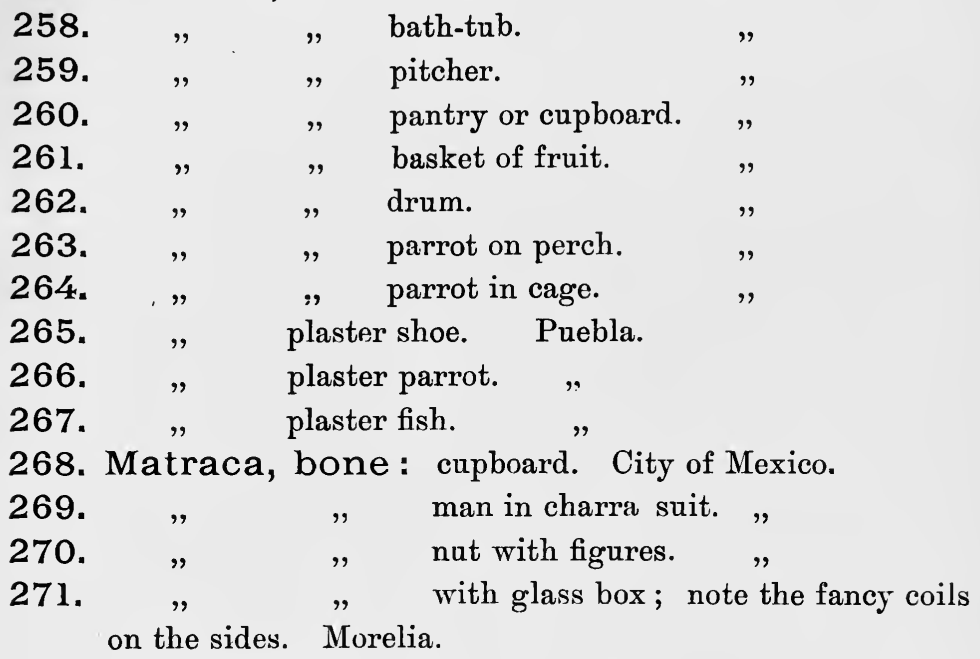

272. Matraca, bone: with ship made of shell. City of Mexico.

\section{JUDASES :}

It is, however, on the day before Easter, the Saturday of Glory, that gaiety reaches its culmination in the public destruction of Judas, the betrayer. For three days or so beforehand, street vendors have sold these figures by thousands. They are of all sizes, forms, and grades. Some are dressed in charræ̃ suits, some are in soldier-uniform, some are horned and tailed to represent the devil: some are beggars and some are fine gentlemen : some are fat and some lean. They range from a few inches to ten feet, or more, in length. They are composed of card or paper-pulp, and have fireworks 
(cuetes, or rocket-crackers) worked into or on them. They are hung over the middle of the street and exploded at noonday. They are often filled with things for the rabble-meat, soap, bread, clothing, candy, etc. The people scramble for these, and run their chances of being hurt by the exploding cuetes, often cunningly arranged with reference expressly to them. The specimens are poor examples, without cuetes.

273. Judas, cardboard: Ixtacalco.

274 .

275.

276.

At the time when these figures are being sold, little figures of Judas in every form and made of pottery or silver are sold on the streets. These are often not an inch in lengtb. They are pinned to coat-lappels and dress-waists during the time of the holidays.

277. Judas, silver: devil. City of Mexico.

278.

279.

280 .

$\begin{array}{ll}\text { dude } & " \\ \text { animal } & "\end{array}$

Corpus Christi: There is no opportunity here to speak of the processions in the churchyard, and the astonishing performances with animals - especially reptiles and verminobserved in towns like Acambaro and Zapotlan. Everywhere, however, the day is looked forward to by children, who promptly beg for their tarasca on getting up in the morning. These are sold on the streets. They are figures of a curious winged creature, somewhat like a dragon. They are usually set upon little wagons, sometimes in such fashion that when dragged the tarasca moves rising or falling. 


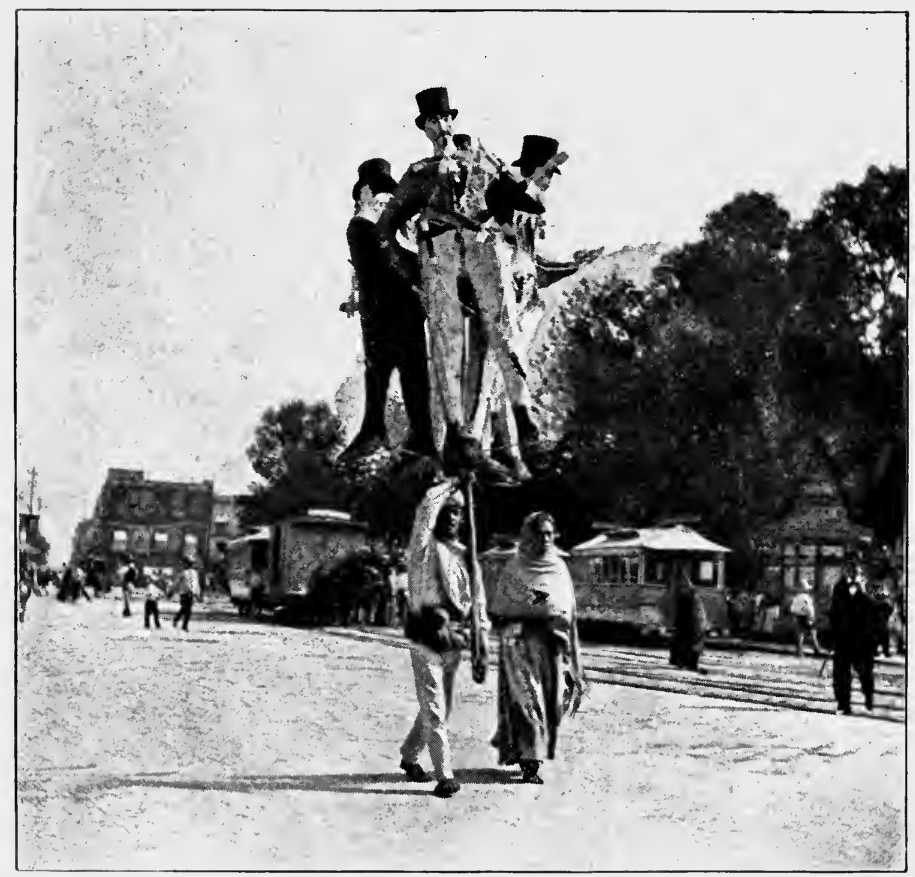

Fig. 11.-SELLER OF JUDASES: CITY OF MEXICO. (Nos. 268-280.) 



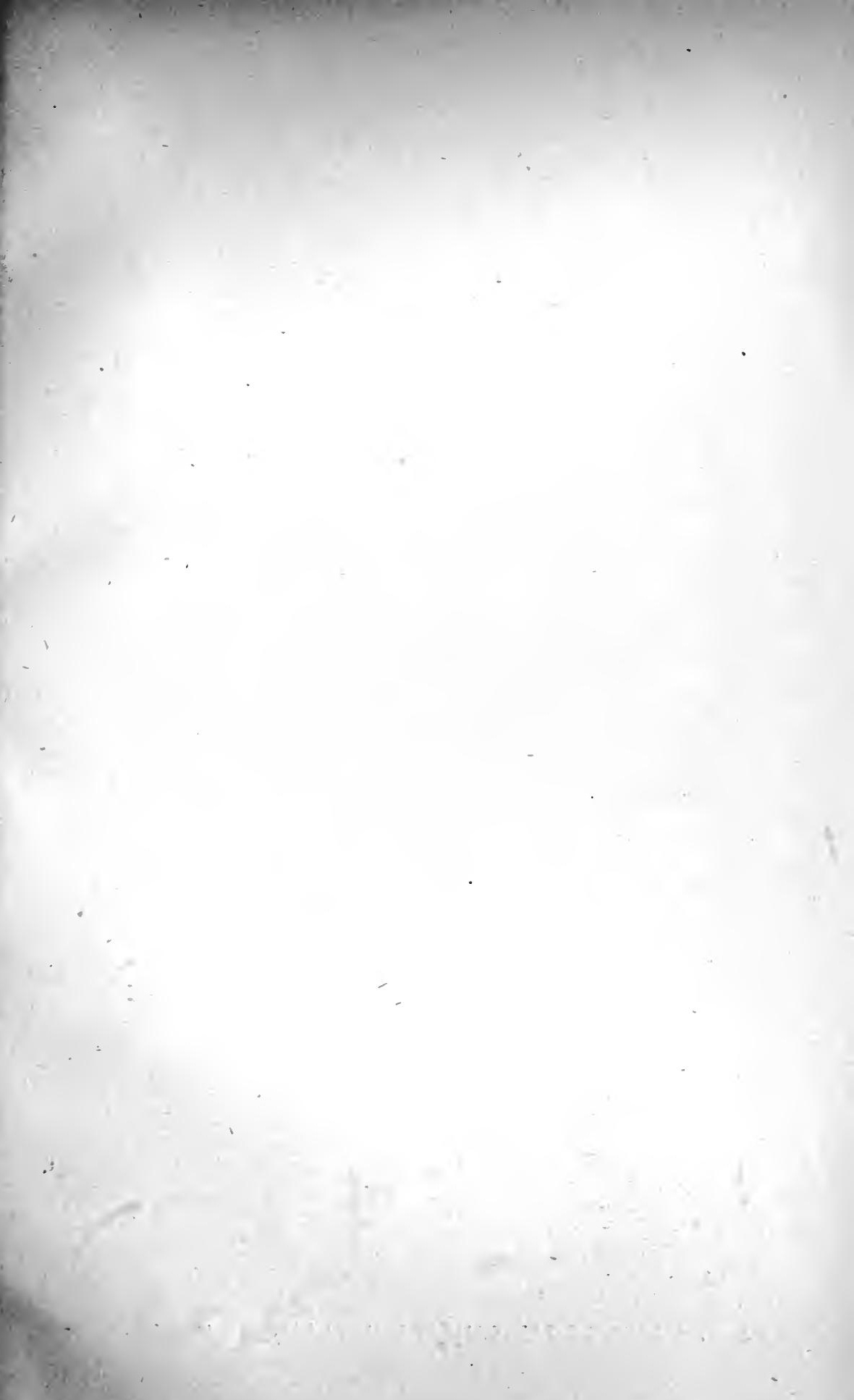




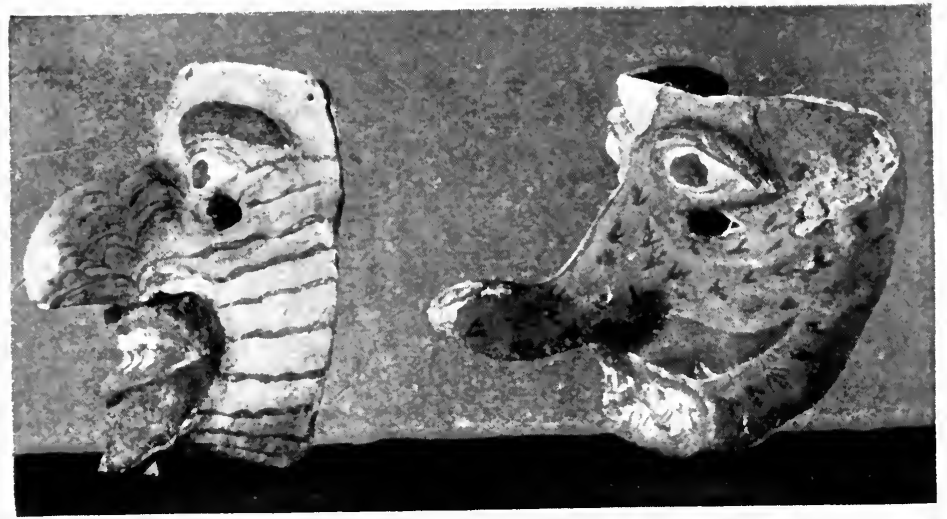

FIG. 12.-MASKS OF TASTOANES: GUADALAJARA. (Nos. 281-291.)

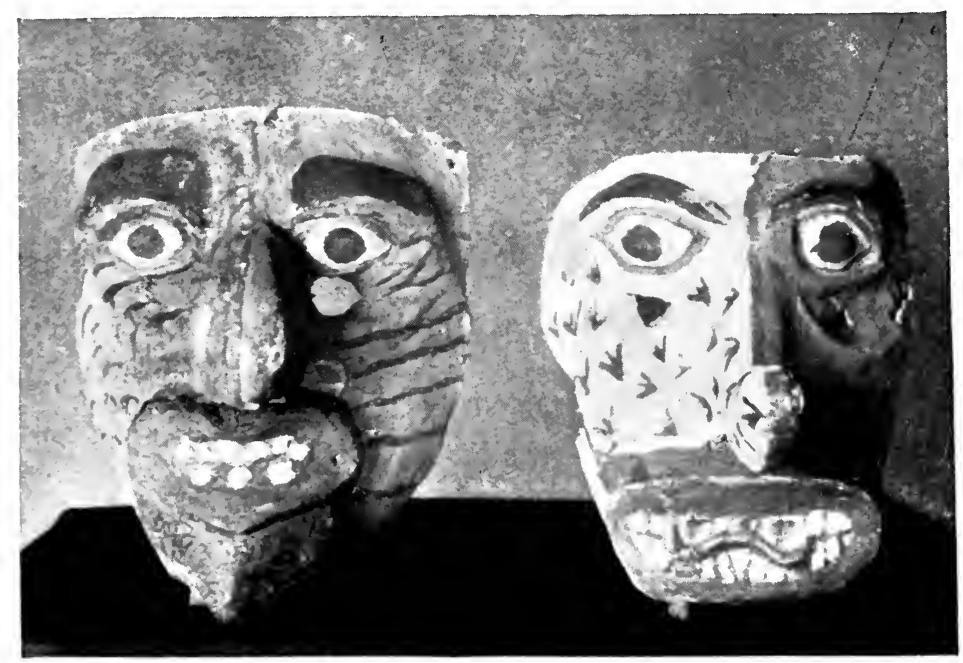

FIG. 13.-MASKS OF TASTOANES: GUADALAJARA. (Nos. 281-291.) 
626. Tarasca. Puebla.

627.

\section{THE TASTOANES :}

On July 25, St. James' Day, certain pueblos near Guadalajara celebrate a drama called by the Aztec name Tastoanes (tlatoani=the masters). This is entirely an outdoor performance. In the drama some passages are in broken-down Aztec. The players form two parties-one, hideously masked and clad, being "Indians" and pagans, the other being Christians. The play, while showing much of the old Indian ideas, is a representation of the victory of Christianity over paganism. For a full description of this drama see the author's paper The Tastoanes (No.619).

281. Mask of leather and plaster: used in the Tastoanes. Guadalajara.

282.

283.

284.

285.

286.

287.

288.

289.

290.

291.

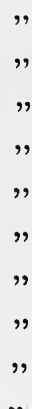

292. Pottery figure: representing actor in the Tastoanes:

\section{King.}

293.

294.

295.

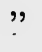

,

,

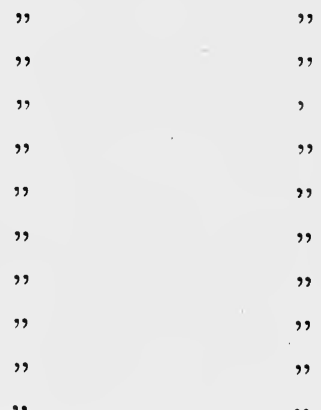

,

Bandelier believes this instrument to be truly Mexican and ancient. 
296. Pottery figure: tastoan. 297. 298. 299. 300.

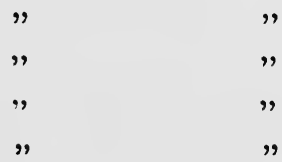

Oct. 31 to Nov. 2: Feast of the Dead. No festival of the year is celebrated with more gusto. We quote some notes made at various towns:

\section{Aguas Calientes:-}

"Boys cut out skulls in cloth and attach them to a second piece, square and the size of the hand. With these they stamp designs in flour or chalk on backs. Others are pinned on to coats. . . . Children ask for 'deaths.' . . Early on a.m. of November 1, all go to church, carrying candles for the dead. Each is named, and prayer is made while they burn. The one to burn longest needed most prayer. . . . If a death in the house during the year, an open coffin is placed, and the bereaved sits over it and narrates his losses. A man happily remarried within a month, now mourns woefully, if never before. Crowds worship the dead priest."

\section{Tezontepec :-}

"Nov. 1st and 2nd, they set out offerings to the dead, consisting of an abundance of bread, fruit, dulces, wax candles, flowers. For grown persons they also place liquors, cigarettes, mole, pulque, tamales. Dogs are muzzled, so as not to molest the dead, who come to take the offerings. The doors of the place where the food is laid out are left open. Masses are said for the dead. The names of the parents are recited. On the last day of the feast the family and neighbours meet and eat and drink the offerings."

\section{Morelia :-}

"Servants say in the morning 'Mi muerto, Señor!' and expect a 'dead,' unless indeed the master is before them with the greet- 


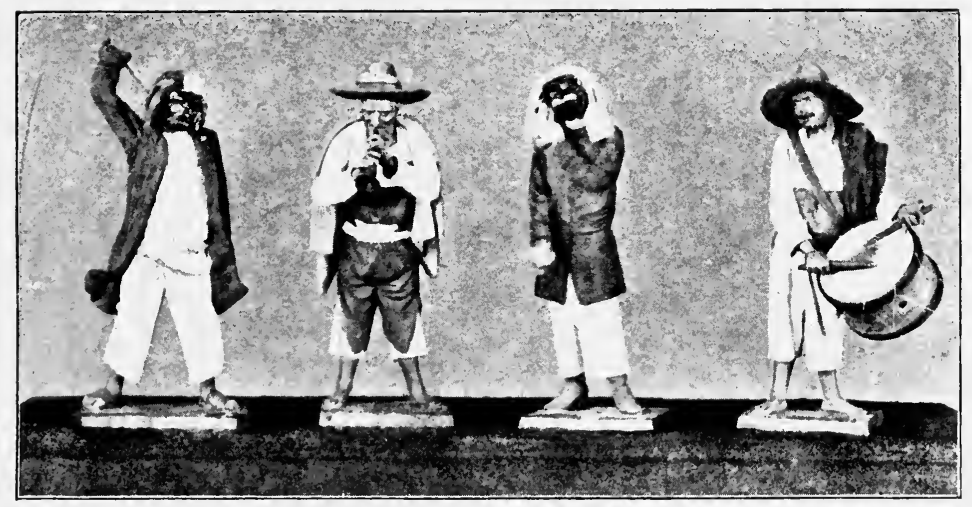

FIG. 14,-TASTOANES, POTTERY FIGURES. (Nos. 292-300.) 

ing. . . . In the cemetery a line of tables is arranged along the wall, upon each of which is placed a skull and a bowl of holy water. On the tables the worshippers place their reales for prayers. The priest passes from table to table, sprinkling holy water and praying. Lights burn all day about the graves, and decorations are placed upon them. On the graves of priests are placed clothes and their portraits."

\section{JIMENEZ :-}

"Nov. 2nd. People go out into the churchyard, carrying their household ornaments and the bed or bedstead on which the dead died ; this is ornamented with lace and curtains, white for children, black for grown persons. Those who have no beds take tables and place them over the grave. These they adorn with strips of paper, gold and silver paper stars, paper flowers, etc. The churchyard is crowded with smiling, gossiping people, who seem quite careless. Candles are burned at the graves. All sorts of refreshments are sold at the gates."

\section{City of Mexico :-}

Madame Lu Barca says: "Last Sunday was the festival of All Suints : on the evening of which day we walked out under the portales to look at the illumination and at the numerous booths filled with sugar skulls, etc., temptingly ranged in grinning rows, to the great edification of the children. In general there are crowds of well-dressed people on the occasion of this fête, but the evening was cold and disagreeable, and though there were a number of ladies, they were enveloped in shawls, and dispersed early. The old women at their booths, with their cracked voices, kept up the constant cry of 'Skulls, niñas, skulls' but there were also animals done in sugar, of every species, enough to form specimens for a Noah's ark." (Life in Mexico, p. 370.)

\section{MUERTOS :}

Sugar pressed in moulds into hollow forms, very thin and 
fragile, is much sold in some places. These objects are white, but may be tinted pink or red, or spotted and dashed with these colours. Those in the collection, Nos. 301-320, are all from Toluca.

301. Sugar form: chili.

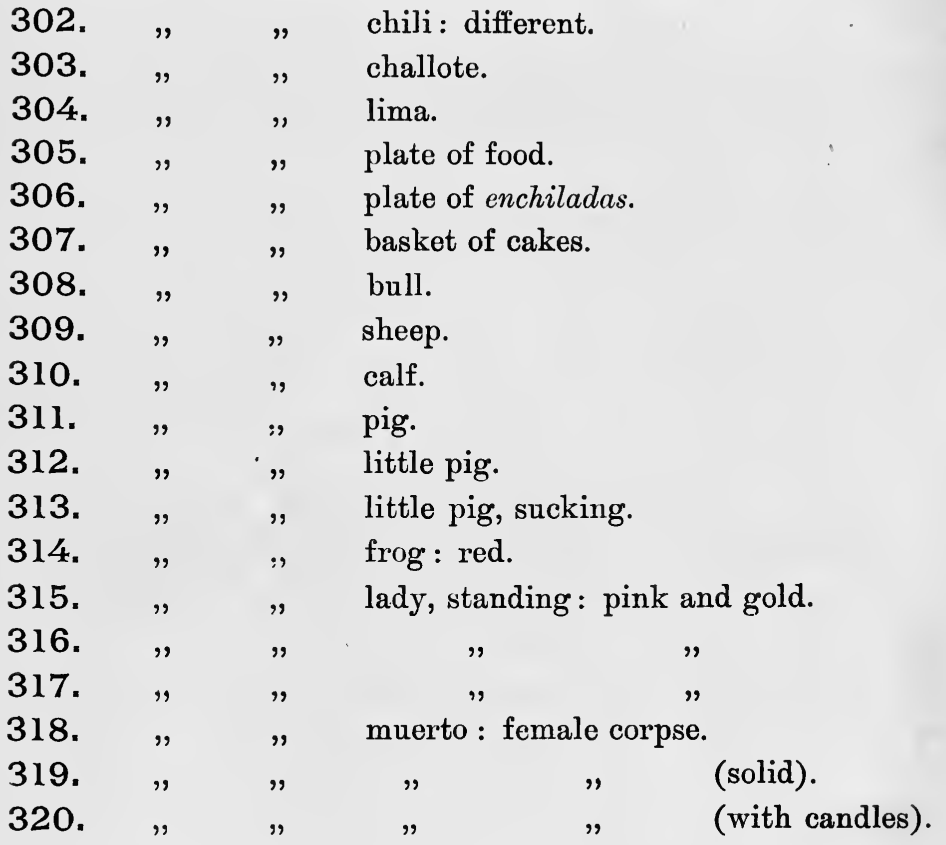

Solid candy or sugar forms represent skulls, corpses, animals, etc. Nos. 321 to 335 are all from Toluca.

321. Candy form : skull.

322: "

323. ,

324. "

325. ,

326. ,

327. , skull and cross.

muerto in coffin.

gravestone and figure.

grave monument.

las animas.

corpse : crude work. 


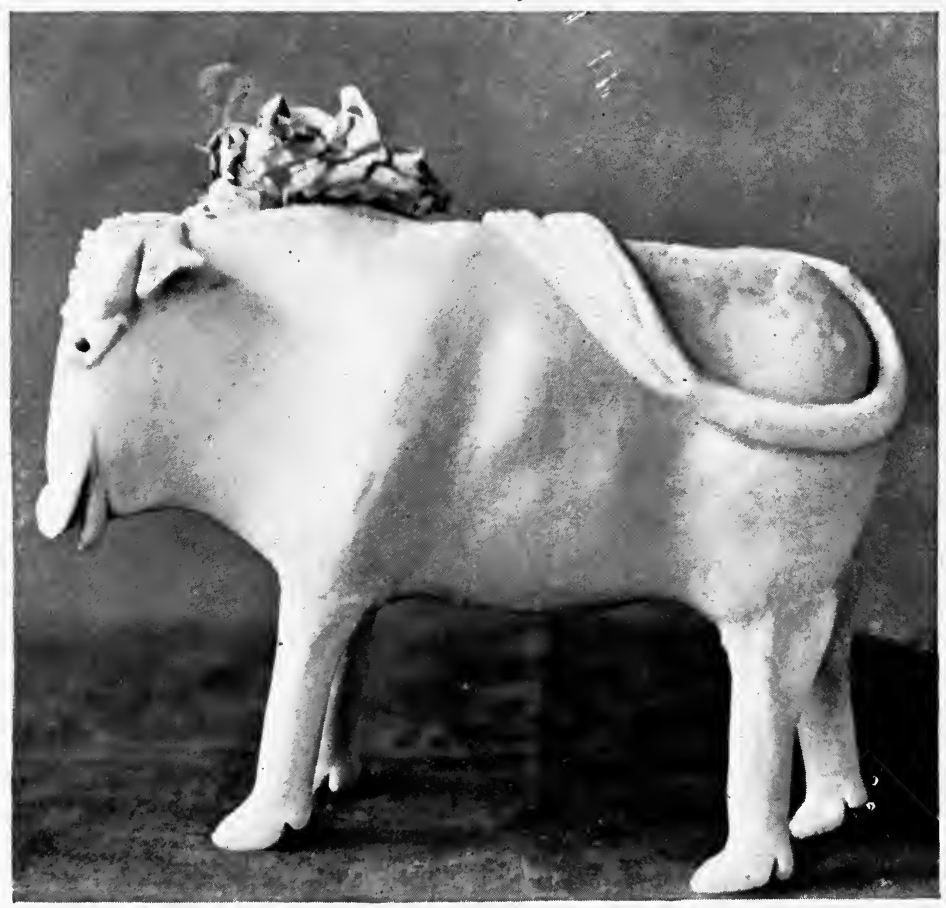

FIG. 15.-THIN CANDY FIGURE SOLD AT THE FEAST OF THE DEAD : TOLUCA. (No.308.) 



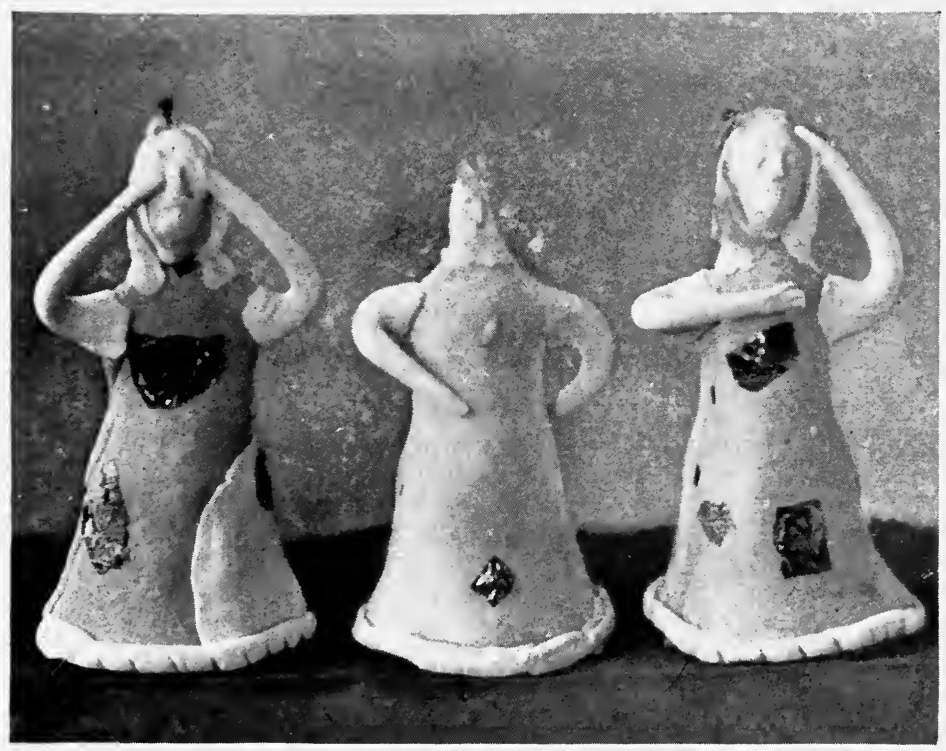

FIG. 16.-THIN CANDIES SOLD AT THE TIME OF THE FEAST OF THE DEAD: TOLUCA. (Nos. 315-317.) 



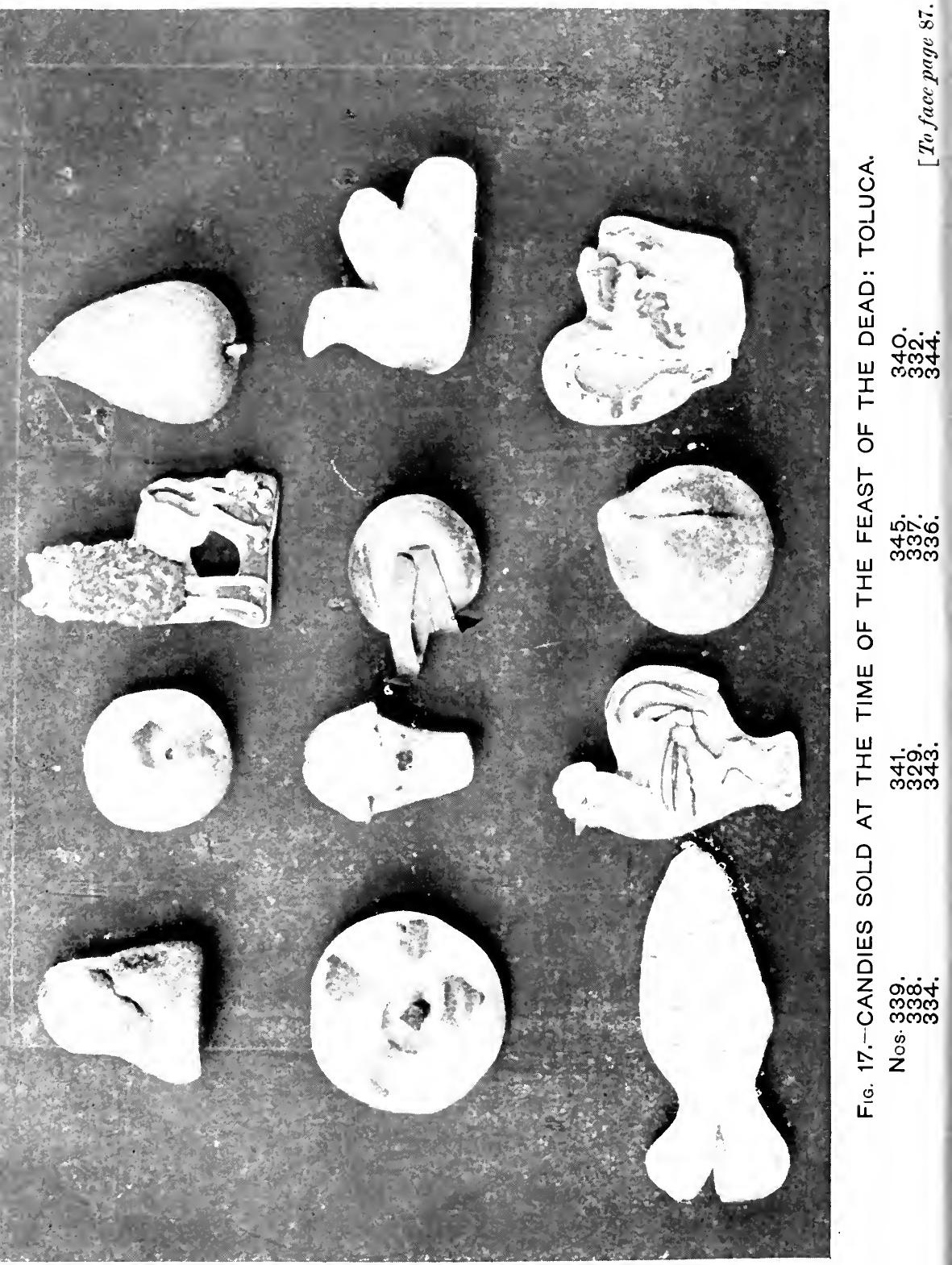


328. Candy form: dog.

329. " " pig.

330. " " pig's foot.

331. " " lamb : crude work.

332. " " dove.

333. " " ducklings.

334. " $"$ fish.

335. " " shoe.

Fruits of various kinds are made of a soft, compact, granular sugar-paste. Nos. 336 to 342 are all from Toluca.

336. Sugar form: zapote amarillo.

337. $", \quad$ fruit.

338. " $", \quad$ coco de agua.

339. $", \quad$ fruit.

340. " " chili.

341. " $"$ pear.

342. " " apple.

Some candy forms are sold at this time which are also sold at other times. Such are Nos. 343-345, from Toluca.

343. Sugar form: rooster.

344. " " swan.

345. " $" \quad$ dog or lion.

A classification of the ghastly toys of this season is not easy. In a rough way they are here grouped as coffins, hearses, processions, tombs, skulls, skeletons, and miscellaneous.

346. Coffin: wood. Containing moss, candies and a sugar skeleton.

347. Coffin: covered with black pebbles. Real coffins are often thus decorated.

348. Coffin: black: pasteboard : candy corpse within. 349. Coffin: black and white: wood: open. An old woman's corpse sits up when a string is pulled. 
350. Funeral car, with coffin: wood.

351. Funeral procession: acolytes, priests, bearers, and coffin: the heads of the persons are of peas.

352. Tomb with terraces: a parapet surrounds the top platform, and tapers are placed at its corners: the king of death looks down from above: two skeletons sit below, with goods for sale: one weeps.

353. Skull: baked clay: the sutures make a + on top of head: lower jaw movable by a string. Morelia.

354. Same: smaller. Morelia.

355. Skull at base of cross : clay.

356. Skull on terraced mound: cross-bones in front : baked clay: Morelia.

357. Skull at base of a hollow tree-trunk: intended for candlestick : baked clay.

358. Skeleton: jointed: pewter, small.

$359 . \quad " \quad " \quad$ with dress: head separate.

360. Skeleton: jointed: wire and clay.

361. Skeleton: dancing jack: cardboard.

362. Skeleton: seated : holds some object.

363. Skeleton : seated : wears a hat: a heap of three monkey heads lies near him.

364. Skeleton: wears stovepipe hat: plays horn.

365. Skeleton: wires and pottery: green and gilt: represents bull-fighter with capa.

366. Skeleton: wires and pottery: purple: drives a hen : wears rebozo.

367. Skeleton: wires, pottery and cardboard: gilt.

368. Skeleton : devil : seated, driving a crane, ducks, etc.

369. Devil : seated : plate by his side.

370. Skeleton: devil : stands, apostrophising a tombstone.

371. Dying bull :

372. Priest: 

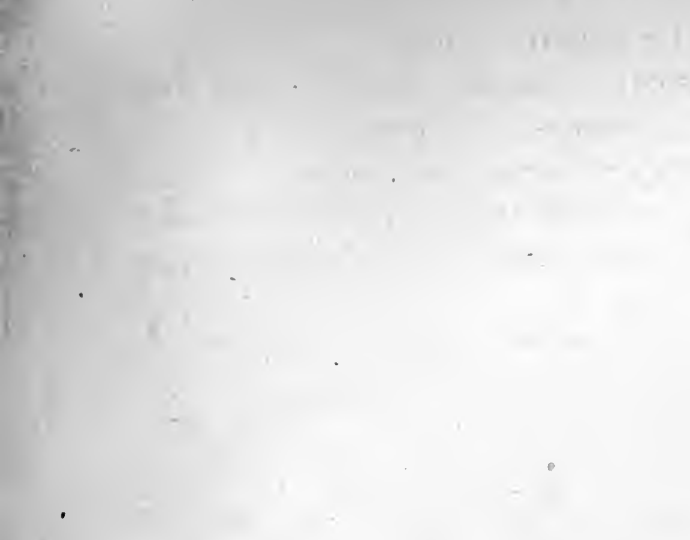

$x=1$

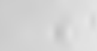

$-$

'

5

-

.

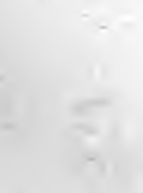

1

.
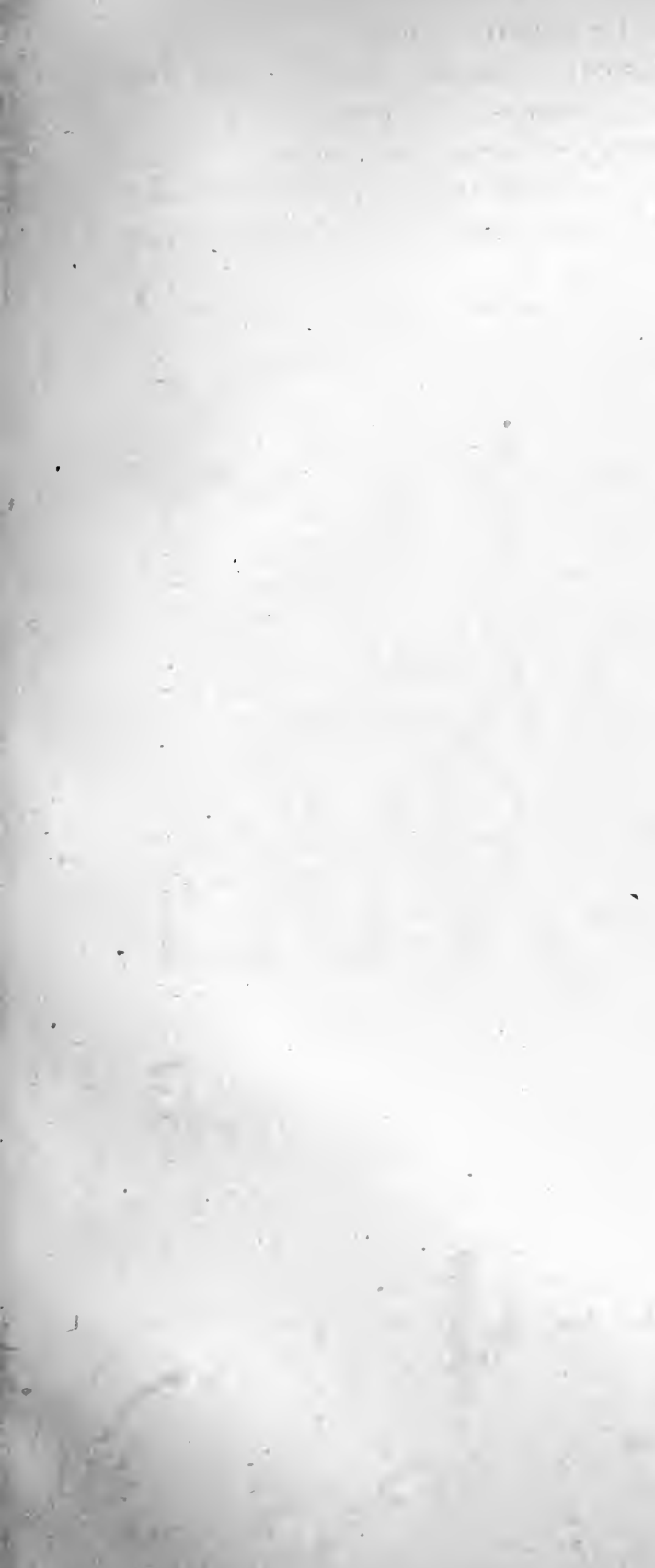


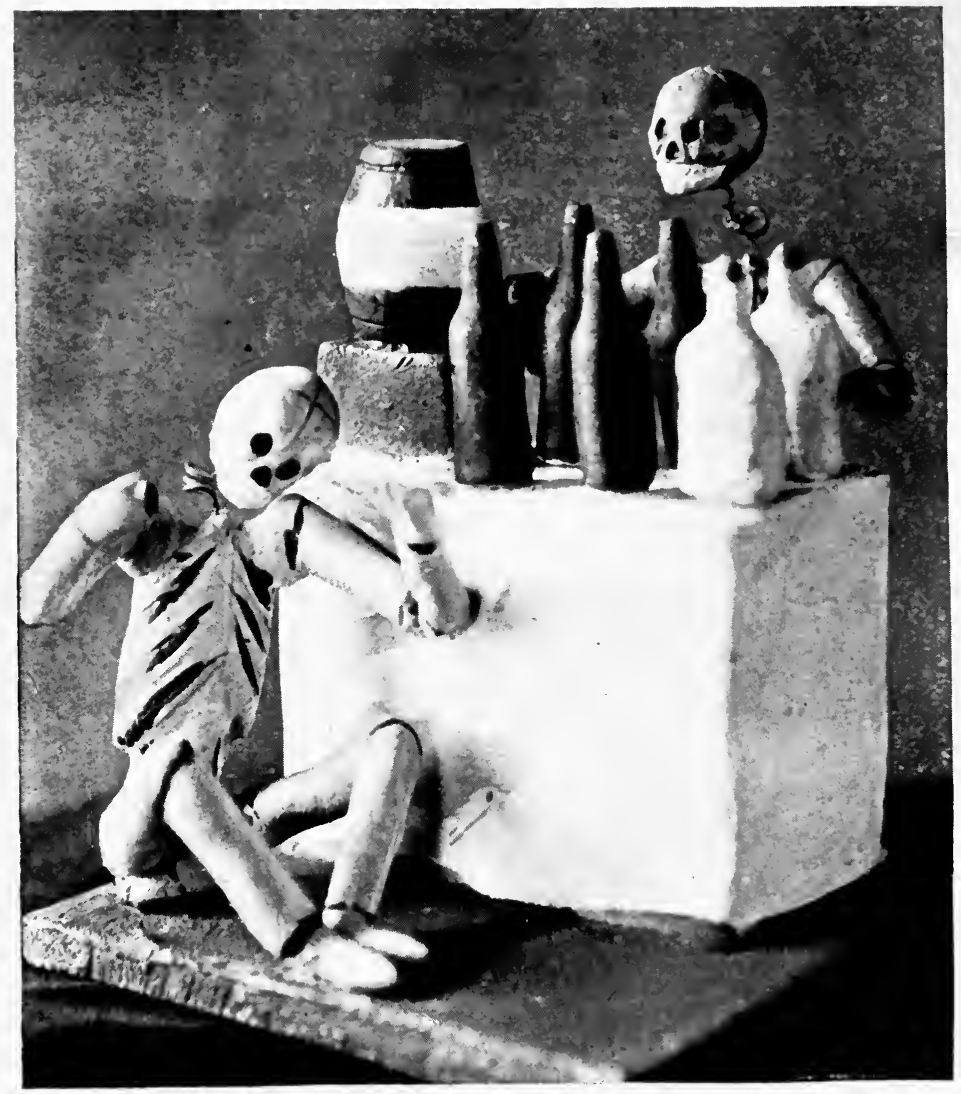

FIG. 18.-MUERTOS: GUADALAJARA. (No. 373.) 


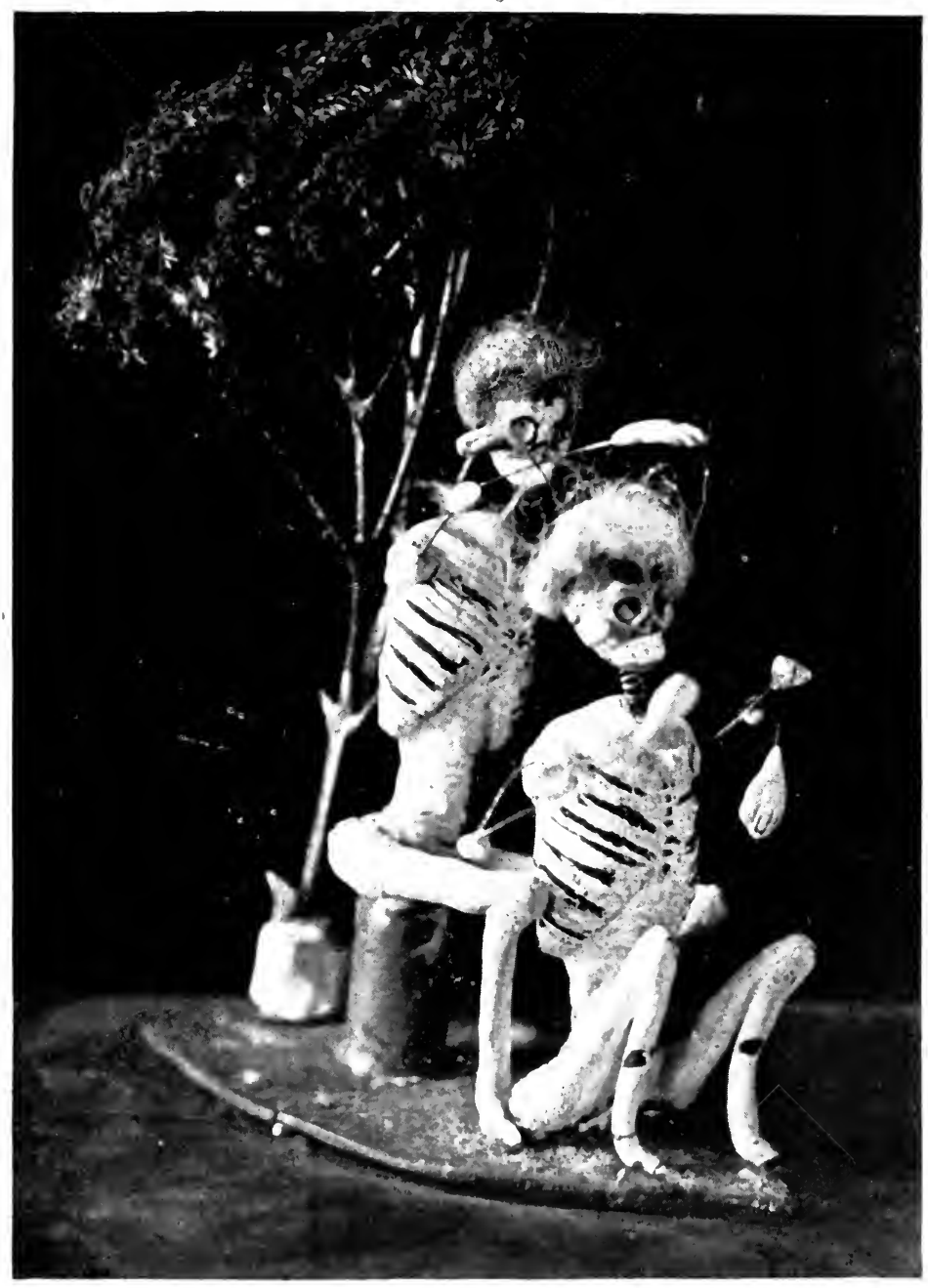

FIG. 19. MUERTOS: GUADALAJARA. (No. 374) 


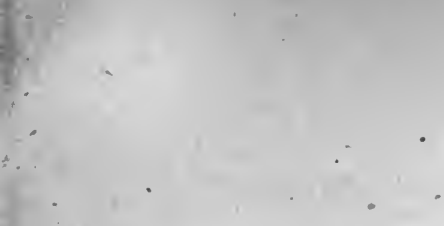

i.

$(1)$

-

$=\frac{1}{2}+\frac{}{2}$

\section{.}

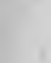




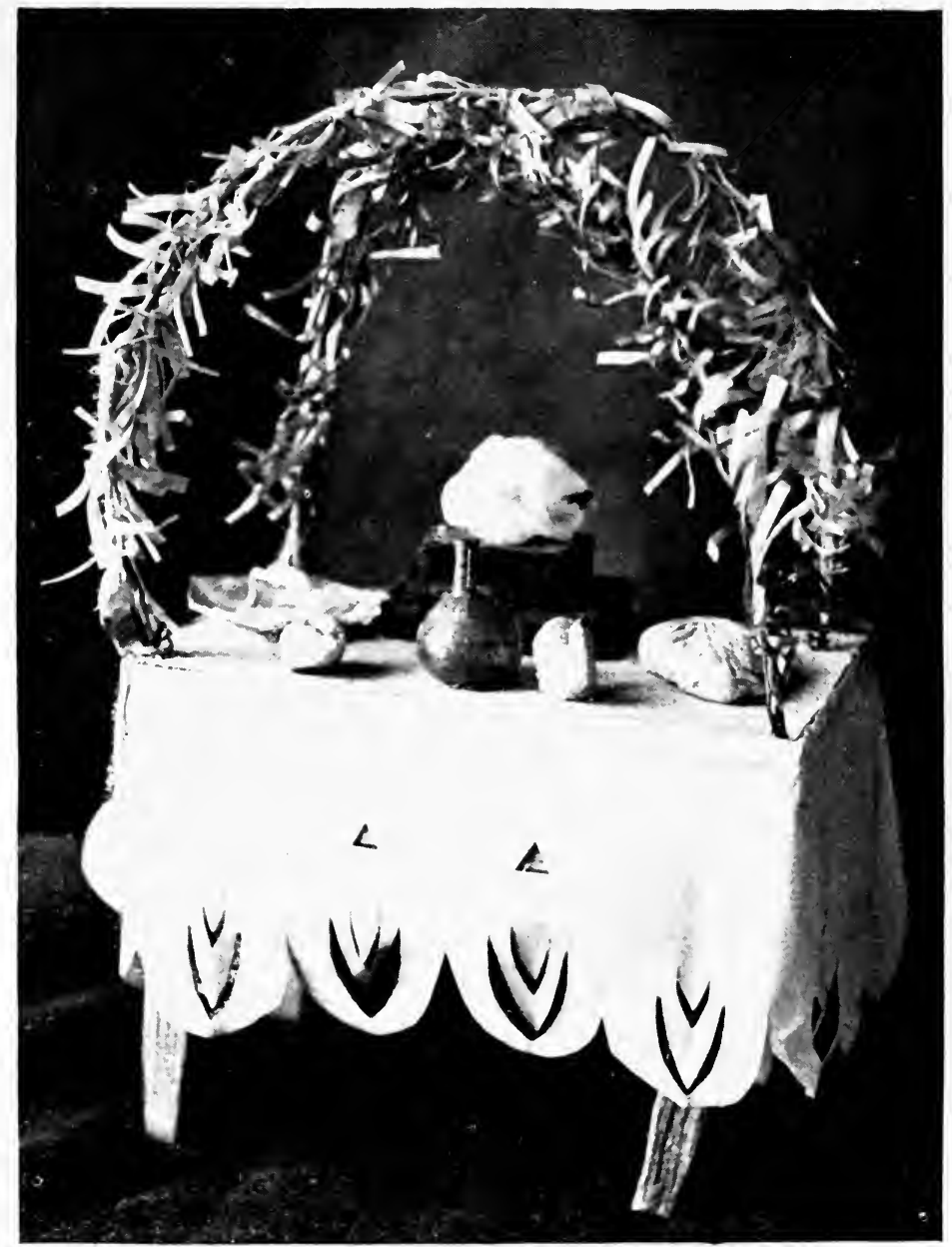

Fig. 20.-TABLE SPREAD FOR THE DEAD: CITY OF MEXICO. (No 386.) 
373. Skeleton: bar-tender: drunken skeleton on ground in front.

374. Skeletons: male and female with wigs: the woman is lousing her companion.

375. Skeletons: female, carrying another skeleton astride her shoulders, pursues an animal ridden by another skeleton.

376. Skeleton: female with upraised whip, threatening two skeleton children before her.

377-80. Groups of skeleton dancers, musicians, etc., with a devil for trainer : much alike.

381. Candlestick and candle: glass.

382. Devil and skeleton gambling over a corpse, which can be made to sit up by pulling a string. City of Mexico.

383. Funeral car: tin. City of Mexico.

384. Monument: black cardboard. City of Mexico.

385. Funeral procession: on jointed strips of wood for opening and closing. Morelia.

386. Table spread for the dead. City of Mexico.

387. Devil, seated, looking at a corpse, which rises by a pulled string. City of Mexico.

388. Leaping frog: surmounted by a skeleton. City of Mexico.

389. Skeleton: in charra dress : of wood: dances on a board. City of Mexico.

390. Madeira nut, with figure of a musician playing a flute: an open book lies on a stand with a skull at its side. City of Mexico.

391. Coffin: wood: black: plain and poorly made. Morelia.

392. Funereal monument: with cross and tapers.

393. Cart with corpse holding cross: when dragged, the corpse flops up and down.

394. Funeral procession: Morelia. 
395. Funeral Procession: Morelia. 396. 397.

398. Skull: sugar. Toluca.

399. Skull: with cross sutures: of clay. Morelia. 40.0. Skull and gravestone: Morelia.

401. Dead laid out on tomb: of sugar. thin and fragile.

402. Corpse: crude work: clay.

403. $"$

404. Skeleton: sitting on monument: holds an open book.

405. Skeleton: embracing a fire-crowned pillar with one arm.

406. Skeleton, by monument: embraces cross with one arm.

407. Skeleton in cart.

408-411. Skeletons: small clay figures: selling produce, arrying musical instruments, reading newspaper, etc. Morelia.

412-413. Jointed Skeleton: singing: holds music in one hand. Morelia.

414. Jointed figure: clay and wire: female: Morelia.

415. Jointed skeleton: clay and wire: Morelia.

416-417. Skeleton musicians: small, jointed: pottery. Morelia.

418-420. Similar: smaller and neater work. Morelia.

All numbers from 346 to 420 without stated locality are from Guadalajara.

December 25th. Three series of popular celebrations are connected with the Christmas season, the Pastores, the Nacimientos, and the Posadas. 


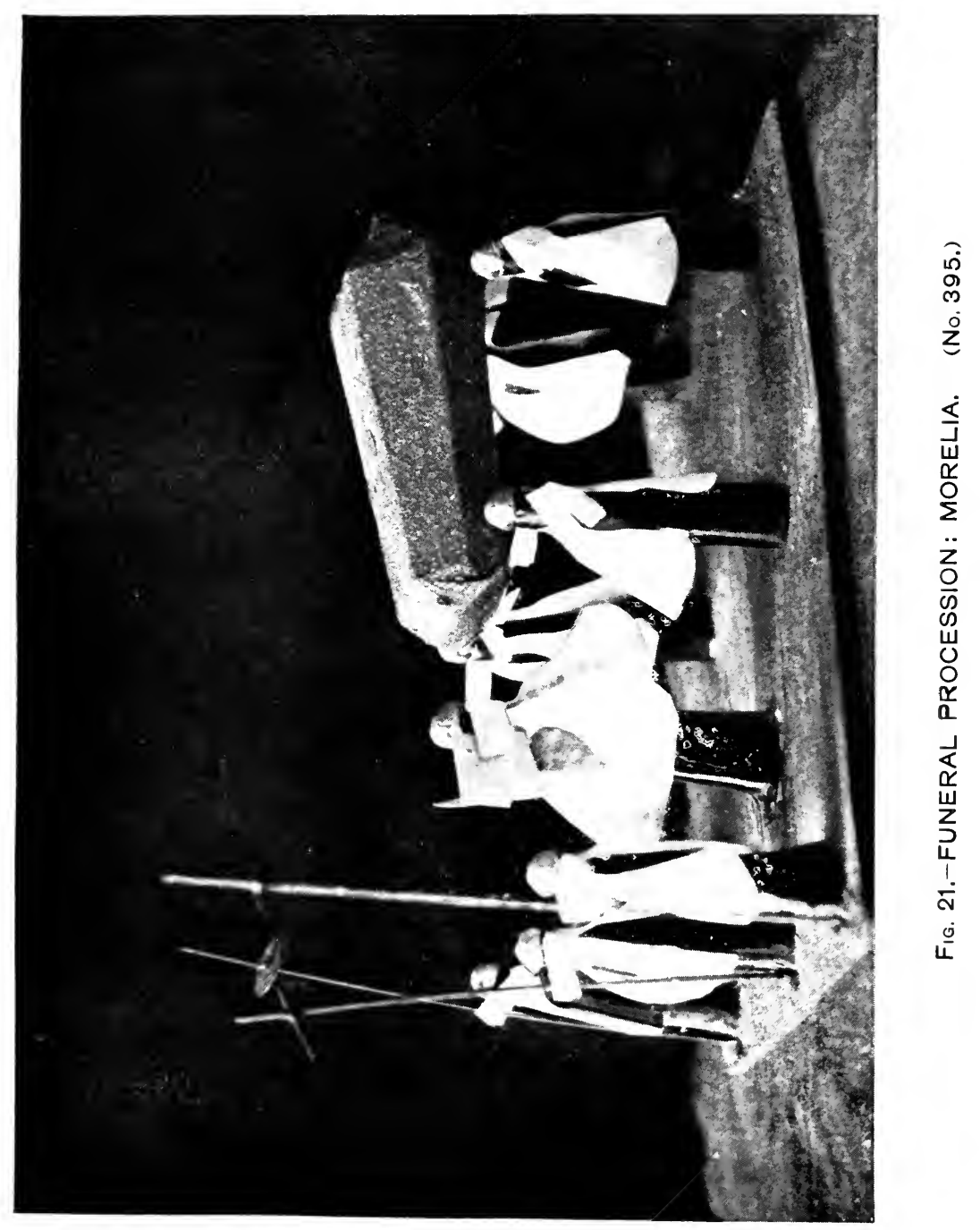





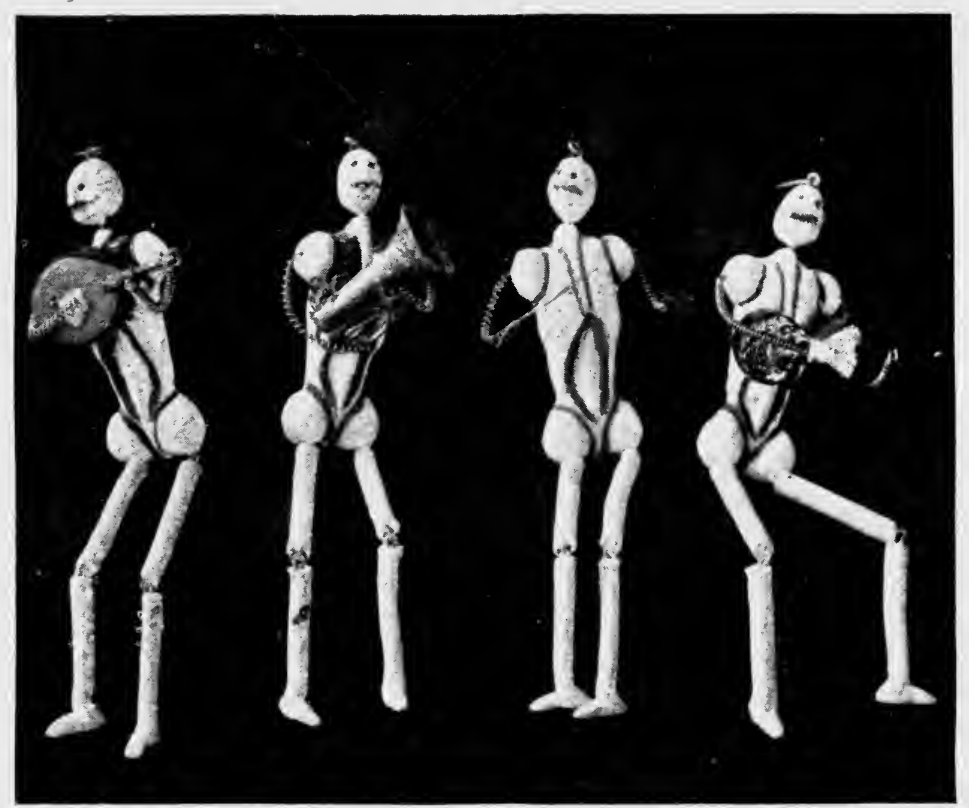

FIG. 22.-MUERTOS: MORELIA. (Nos. 416-417.) 


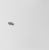




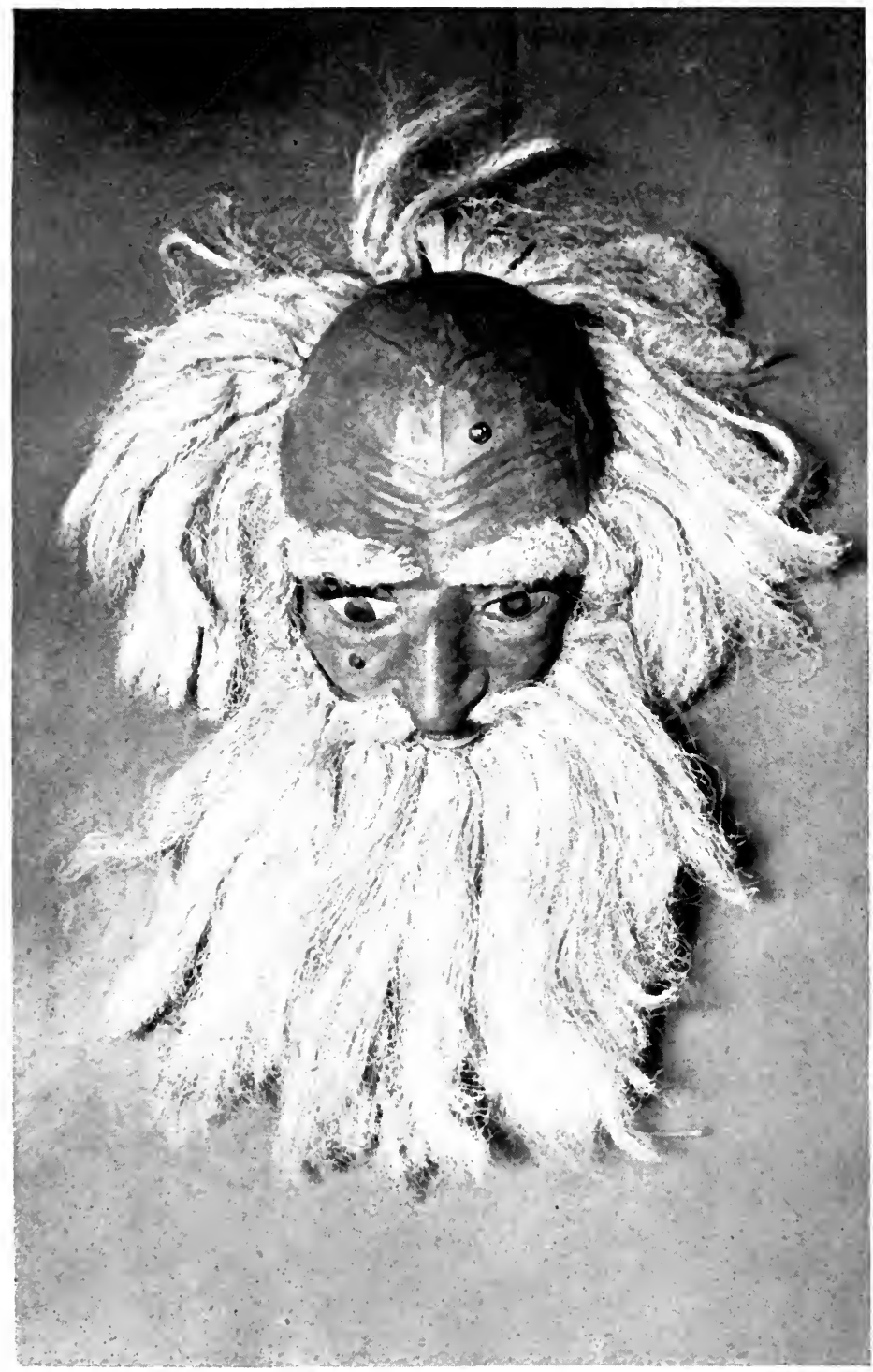

FIG. 23. MASK OF HERMIT IN THE PASTORES: GUADALAJARA. (No. 421. 


\section{THE PASTORES :}

A great variety of popular dramas are performed. These are generally open-air miracle-plays, given by a self-trained company. The birth of Christ and its effects upon the world are represented. Devils, angels, and the shepherds (pastores) are the usual actors. The play is given by dialogue, song, and action. Some of the pieces are certainly old, and many of them show considerable literary and musical merit. The world lost through Adam's sin, the promise of a Saviour, the announcement to the shepherds, the birth of the Saviour, the visit to the child, the rejoicing of a redeemed world, are always represented. While the expression is often fine and true, there is a queer mixture of coarse and broad jocularity. While a number of these Pastorelas have been printed in cheap book-form, the knowledge of them is usually gained from oral tradition or from manuscripts. A number of these plays are given with rather brilliant stage effects in the theatres of the more important cities.

421. Mask : of the Hermitaño-the Hermit-who, though of venerable and pious appearance, is usually the coarse joker and buffoon of the play. Guadalajara.

422. Mask : leather, with pendent tongue and mouth that opens and shuts : represents a devil. Guadalajara.

423. Pottery figure. Pastor.

424.

These shepherds are the actors, who give the name to the play. They are numerous, and form a chorus singing and marching with pretty evolutions. Guadalajara.

\section{NACIMIENTOS:}

In many houses a nacimiento, or representation of the birth of Christ, is built up with considerable care and at some expense. While the scene of the child in the manger is always represented, it is sometimes but a small item. A 
great landscape may be built of rocks and spars, and in this may be placed artificial trees, artificial flowers in pots, and figures representing all sorts of biblical scenes and personages, animals, persons, objects, etc. While these may be tastefully and handsomely arranged, they are often quite grotesque from lack of attention to consistency and proportion. The figures used are usually of wax, and at the Christmas season the streets are full of tables and stands where such are sold. To show their range and variety a partial list of things seen for sale at Morelia in December, 1897, follows; all were in wax.

Cabbages: maguey plants: birds and animals : individual figures of the infant Christ, Mary, and Joseph. (The infant is usually swathed in red, Mary is always dressed in blue and white, and San José in green and yellow.) Among groups of figures for nacimientos were women selling pottery; men irrigating fields; John the Baptist baptising Jesus, with a broom for sprinkler and a white dove hovering above; the Temptation in Eden, with Adam and Eve and the Serpent; the Expulsion from the Garden, etc., etc. As an example of the way in which these are combined, the following describes one nacimiento:- the whole of one side of the room was occupied with a landscape composed of rockwork and representing hills, valleys, etc. At one side was a train of packmules and an attack of bandits: at its side and the central piece was the Garden of Eden from which the first pair were being driven out by an angel with a flaming sword. Adam and Eve were being driven forth into a desert. Next to this, however, was another group representing the Expulsion; but this time the race-parents are going forth into a scene of festivity - farms, cows being milked, crops being gathered, old women contentedly smoking, a band of music playing, and a company of young people gaily dancing. 
. 


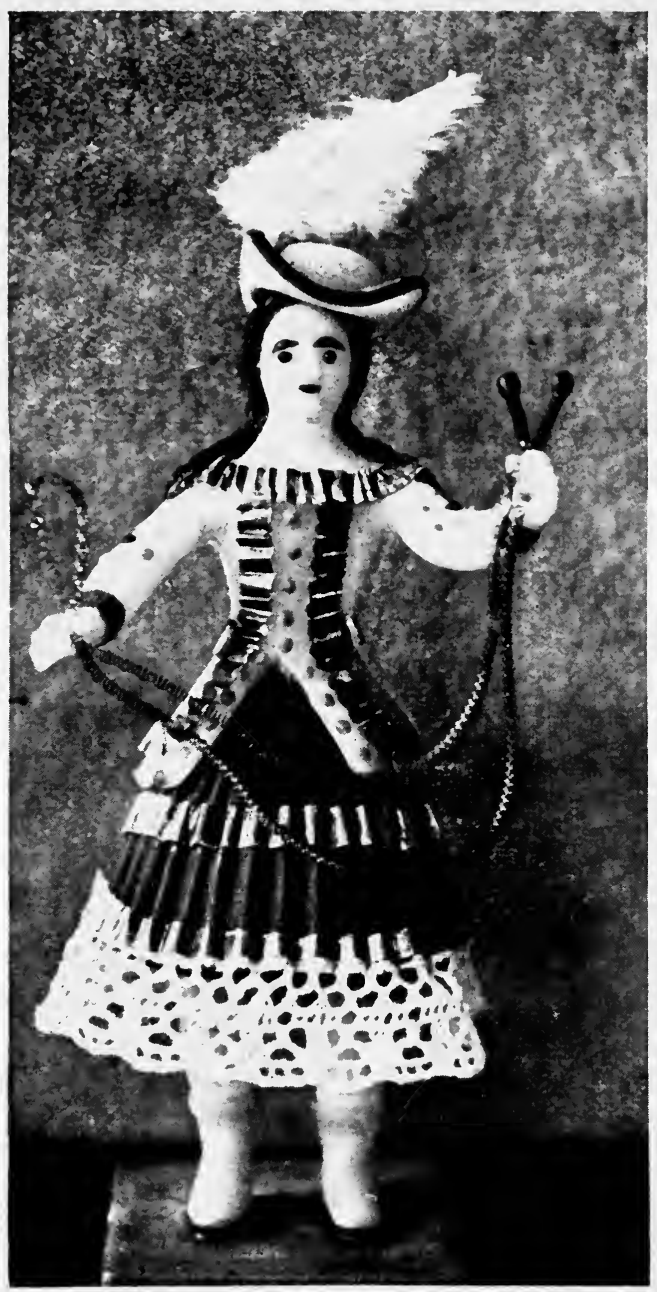

FIG. 24.-WAX FIGURE FOR NACIMIENTO: TOLUCA. (No. 425.) 
425. Wax Figure: dancing girl.

426. " $"$ guitar player.
427. negro.
428. " priest.
429. Wax pitchers.
430. Wax birds.

All from Toluca.

431. Figure in clay: Mary. Guadalajara. 432.

$"$ Joseph. "

\section{POSADAS :}

Of the posadas a writer in The Mexican Herald, December 17, 1897, says :

"The posadas are a characteristically Mexican celebration. They commemorate the journey of Mary and Joseph from Nazareth to Bethlehem, whither they went in obedience to the mandate of the Roman Emperor to be enrolled in the census. This journey, performed by Mary mounted on an ass, which Joseph guided, is supposed to have occupied nine days. Each evening the humble couple naturally approached some dwelling on their route, to beg a night's shelter. In solitary regions it is easy to imagine that the favour would not be readily granted, and that the holy pilgrims met with more than one rebuff. Now it is this nightly episode that is commemorated in Mexican houses by the posadas, or the begging of the posada (pedir posada), the word posada meaning shelter, lodging or entertainment.

" It is customary for a number of Mexican families to club together to celebrate the nine nights among them. At the appointed hour the guests assemble at the house chosen for the particular night. Each guest is provided with a taper; and it should be noted that the servants are sent for from the kitchen, and are invited to take part with the people of the house in what is regarded as a religious ceremony. 
"A procession is formed, at the head of which are carried figures of Mary and Joseph, she riding an ass and he leading it, while overhead hovers a very florid and gaudily dressed angel guiding the pilgrims on their way. The dresses of the holy couple are very incongruous, consisting of green, yellow, or other gay-coloured satins. St. Joseph is usually represented with a pilgrim's staff and gourd.

"The procession marches several times around the corridors of the house, intoning what is known among Catholics as the Litany of Loretto, which is a series of poetical invocations in honor of the Virgin. When the Litany is finished, two or three of the party enter one of the rooms of the house, which according to Mexican custom open on the corridor, and having once entered they close the door on the rest of the party, at the head of which are the figures of the Virgin and Joseph. A dialogue in chanted verse then ensues, the scene intended to be represented being the nightly request of the pilgrims for shelter from the cold and dangers of the road. The party outside speak in the name of Joseph and beg for admittance for his wife and himself. The people of the house, represented by those inside the room, at first deny the favor, but at last relent, touched by the innocence and distress of the pilgrims. The versicles are very simple and are sung to a tune of immemorial antiquity in Mexico. Here is a specimen, freely translated, of the versification.

\section{JOSEPH.}

In heaven's name,

I beg for shelter,

My wife to-night

Can go no further.

Asswer.

No inn is this,

Begone from hence,

Ye may be thieves,

I trust ye not.

"And so on in the same strain. When the doors are thrown 
open, the pilgrims are placed on an improvised altar decked with quantities of lighted tapers, with shiny tinsel and toys of small intrinsic value. All the party kneel and some prayers are recited. After that, a tray is passed round containing small jars filled with candy. Each guest is invited to take one, and with this compliment the ceremony, properly speaking, ends. For in the simple patriarchal days of the viceroys the posada was a strictly religious custom, and in a few old-fashioned families it is so still.

"But in most Mexican houses it must be owned that the posadas are only a pretext now for having a good time. The religious exercises are got through with in the quickest and most perfunctory 'manner possible, and many times without the decorum desirable on serious occasions. A dance and general romp follows, which is kept up until the early hours of the morning. It is for this reason that the archbishop has disapproved of the custom of observing the posadas, which he declares were all very well at one time, when the character of the people was simple and ingenuous, but which now are conducive to irreverence. It is to be hoped, however, that the posadas will not die out, for undeniably it is a pretty sight to see all the members of a family, from the grandsires bent double with age to the small tot of five, marching round the corridors with their lighted tapers, their voices mingling in the petition, 'Ora pro nobis.'

"The ninth night of the posadas, that is, Christmas Eve, is celebrated on the most extensive and luxurious scale of all; and generally the wealthiest of all the families that have clubbed together agrees to give the entertainment of the night in question. As on that night, too, the Saviour was born, the figure of an infant is carried in procession and is placed in a manger between the ox and the ass in a prettily adorned cave which is intended to represent the stable where Mary and Joseph took refuge when they found that there was no room for them in the inns.

"The Christmas tree is not a native institution, though it gives indications of becoming naturalised. In its stead, Mexican children have what they call a piñata, which affords them just as much fun. 
The piñata is a large earthenware jar, which is covered with colored tissue paper, often in such manner as to represent a ship, a balloon, a grotesque human figure, or other object. This jar is filled with all sorts of dainties dear to children-oranges, raisins, candy, pea-nuts, etc., and is hang up in the corridor or courtyard of the house. Each of the children and grown-up people is blindfolded in turn, and after being turned round once or twice has a stick placed in his or her hand and is invited to break the piñata. The other guests have to be on their guard, for the wielder of the stick is generally, after being turned round, quite out of his bearings, and often brings down his stick within an ace of the head of one of the party. He is allowed three trials, and if he is not successful the handkerchief is removed, and another takes his turn. At length a crash is heard ; someone has made a true hit, the piñata is broken, and the good things fall in a shower to the ground, and a general scramble ensues among the young ones to obtain possession of as large a share as possible.

"Last night was the first of the posadas, and the zocalo, where are situated the stalls for the sale of piñatas and figures of the holy pilgrims, was a picturesque sight, with its concourse of people, its cressets, bonfires, and heaps of pea-nuts, not to speak of the dazzling array of the objects for sale. It was a children's paradise, and no one can be so surly or misanthropical as not to enter into the delight of the little ones. What a throng of tender recollections of childhood does Christmas erer bring back!"

At posadas favours are often given out. In the houses of the common people these are usually paper baskets or boxes filled with cheap candies. In richer families they give pretty little vases or dishes of china or glass. These gifts are sometimes extravagant, and at one posada in the City of Mexico it is stated that 15,000 to 20,000 pesos were spent, and the favours were little baskets of bonbons, the bottom of each basket being a twenty-dollar gold-piece. Where these parties are chiefly 


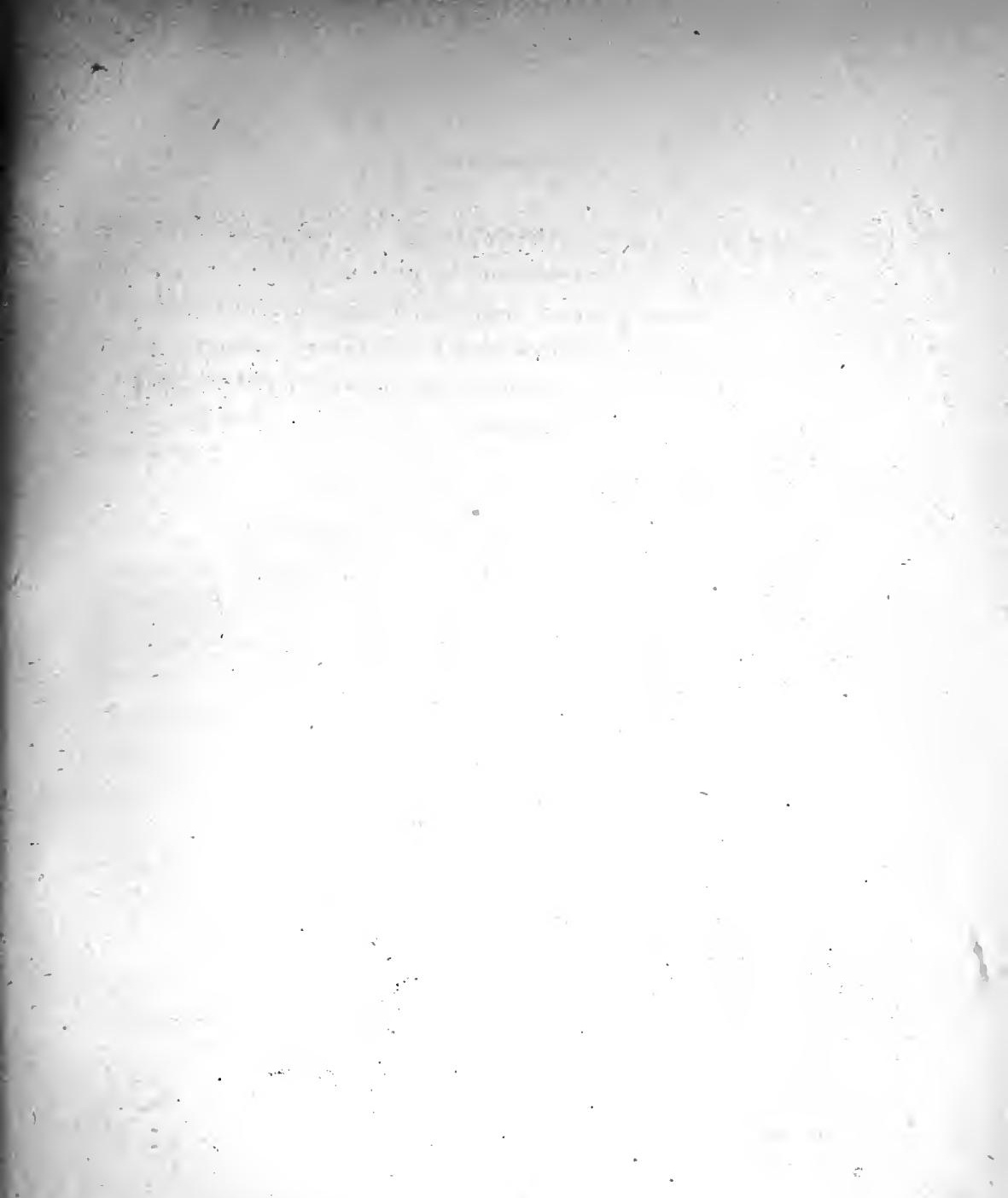




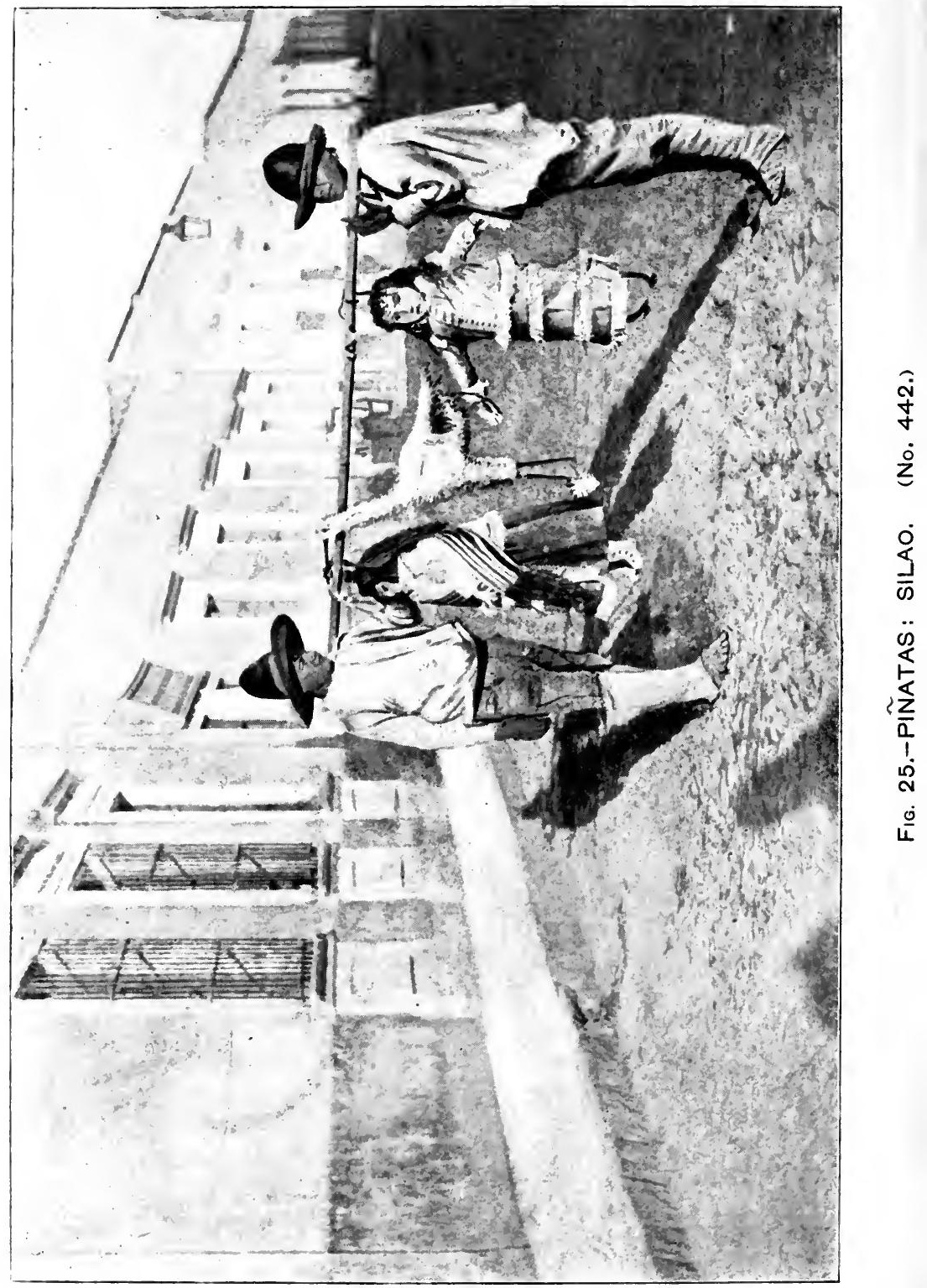


for children, tin whistles and tambourines are used to give time and accompaniment to the songs. Some of these tin whistles are arranged to be filled with water, when they give out clear bird-notes. 'Posadas for children are conducted in some of the churches, and where so these whistles and tambourines are used with pretty effect, boys using the former, girls the latter. The bird-whistles are used in the midnight mass of Christmas Eve in the cathedral at Guadalajara. The effect is novel and very sweet. Piñatas are of all sizes and degrees of elaborateness in decoration. They are made to represent flowers, pineapples and other fruits, human beings, naguals, quadrupeds, birds, fish, devil on bicycle, devils, lyre, boat, cornucopia, etc. While usually filled with bonbons, pea-nuts, fruit, etc., they may contain a quite different filling. Water and ashes are not uncommon contents. At a posada given by the Archbishop of Morelia one time, it is said that the only filling of the piñata were black zapotes. This fruit is soft, and mashes easily: its interior is black and disgusting; the garments of men, women and children who scrambled for the contents of the piñata were in a fearful state. On the other hand, the deluge may prove to be of sweet perfume.

433. Piñata : small-flower. Toluca.

434. man.

435. " fanciful form. ",

436. " fish. Toluca.

437. $"$ Toluca.

$438 . \quad, \quad$,

439. " "

$440 . \quad " \quad "$

441. " "

442. Photograph: Piñata-Sellers. Silao.

443. Paper basket: for Posada. Morelia.

444. 
445. Paper basket: for Posada. Morelia.

446. Paper box-form of ice-cream freezer: for posada. Morelia.

447. Rattle of tin: for posada. Morelia.

448. Tambourine: tin ", "

449. Whistle: tin : for filling with water : used at posadas. Morelia.

450. Whistle: tin : for posada use. Morelia.

Dec. 28th. Los Santos Inocentes: Holy Innocents Day is observed in Mexico as a day of practical joking somewhat like our April Fool's Day. Persons are sent on fools' errands, are invited to grand feasts which are not forthcoming, etc. A common practice is to promise a person something desirable, and then fulfil with a miniature and worthless object of the kind promised. If one borrows a good and servicable article he may repay with a small and useless one, etc.

628. Plates: sold for Dec. 28th. Puebla. 629. Candies 


\section{CHARMS AND AMULETS.}

Charms and amulets proper are by no means so common as one might expect, having been largely crowded out by church scapulars and medals, the use of which is practically universal. When charms are worn, it is rarely about the neck. Both men and women among the common people in Mexico wear belts or sashes. What objects they carry, from any desire to gain an advantage by so doing, are usually wrapped in the belt. The list which follows is almost all that I have been able to find in use, whether specimens occur in the collection or not.

\section{Venenillo Soliman:}

The seed of this plant is sold at all shops of remedios. It is carried in the pocket for curing kernel in the groin.

\section{Ojo de Venado: deer's eye.}

Sea-bean worn on a cord about the neck by babies who have had the Evil Eye cast upon them. The symptoms of Evil Eye are that one or both eyes of the child begin to shrink, and it suffers from diarrhœa.

453. Chuparosa: A humming bird wrapped in the faja or belt to increase a man's industry.

Often, when a man is a vigorous worker, they will say : "Look at him work, he must have a humming bird in his faja." The bird is usually wrapt or decorated with ribbons or threads of bright wool.

454. Hueso de Muerto: dead man's bone.

The finger-bone worn in the girdle gives success in enterprises 
and industry in work. It should be wrapt with green silk to have the greatest power. This, as well as the last, is a favourite amulet of prostitutes; they are worn to draw trade.

455. Hueso de Muerto: vertebra.

While the finger-bone is the favourite bone for men who wish to be industrious, a part of the spinal column, especially the coccyx, is most sought by prostitutes, from a fancy that a man's power is lodged therein.

456. Cascabel : rattle of rattlesnake. This is placed inside a violin or other musical instrument, to make it play well.

457. Cantarida : spanish fly; buprestid beetle. Carried by prostitutes to draw trade.

458. Ticus : a black bird.

Is worn either whole or in part, in the belt, to cause reciprocation of love. Worn by either sex. The specimen here is a leg: the other leg of the same bird was bought by a mestizo woman, who wished the love of a Spanish gentleman.

Hormiga de hueso: bone-ant. Wrapped in a bit of paper, it is placed in the faja, on the side opposite to an aching tooth to cure it.

Cuentas de Coral: coral beads are worn around the neck for jaundice.

459. Piedra de Iman: lodestone.

To carry a lodestone in one's faja is to draw success in selling, money-making, or other enterprise. It is however particularly used by prostitutes. It is a live thing and needs drink and food. It must be put into water on Fridays to drink: it is then put in the sun, and later given iron filings for food. To grease it, kills it. A knife rubbed against it becomes poisonous, and a person stabbed with it will surely die. It must not not be worn at mass, as it contains a devil. Laid 
upon a sore or a spot of proud-flesh, the bad part will be eaten out by the stone and a cure effected. It must not be worn during a storm, as it draws lightning: nor should it be used in curing sores upon the head in rainy weather.

Escudo : a gold coin.

It is worn in the faja by merchants, to secure a good business. A hatter was named, who wore a golden escudo in his belt. Often advised to sell it, he replied always- "No, when I make a hat and go to sell it, I can sell it at once on account of this."

460. San Benito de Palermo: painting of this black saint on tin.

Such are sold by hundreds in the little markets. Though chiefly used by prostitutes, it is said also to be used by market women who sell tortillas, etc. It is frequently carried upon the person. No particular reverence is shown it during prosperity; but if fortune fails to smile, the poor saint has a hard time of it. $\mathrm{He}$ is then beaten, reviled, thrust into the fire, put head first into the water-tub, rubbed with filth or put face downwards in the manure-heap, until he sends improvement in trade. 


\section{WITCHCRAFT.}

Is commonly believed in. The principles among the mestizo class are quite those of European witchcraft generally. They have been reduced to print, and books of black magic are easily purchased. Quite a trade is conducted in prayers to the devil, written formulas, etc. In most towns of size some one or more persons may be found who have such for sale.

461-469. Collection of objects used in witchcraft.

This is an exact duplicate of an outfit gathered at considerable outlay of time and trouble by two young men, brothers, who had determined to perfect themselves as professional witches. Another brother, discovering the plan, destroyed the outfit. It consisted of the following articles:

\section{Cotton.}

462. Dried Humming-Birds.

463. Ends of stearine candles, which had been burned around the dead.

464. Candle of the Santissimo.

465. Rod of oak: Moses' rod.

466. Rod of cypress: Solomon's rod.

467. Sugar syrup.

468. Oil : such as is burned before the host.

469. "Black Magic."

Manuscript prayers to the devil, formulas, etc.

These young men never made much advancement in their art. On one occasion they went a mile or a mile and a half from the city gate with their oak rod. With it they traced a circle in the road, and in it placed a black hen. (This is best 
if the meat is black.) They killed her by slashing her to pieces with a knife, dividing the flesh into four portions, and placed one at each of the cardinal points. Then, entering the circle, they awaited the coming of the devil. In the darkness they heard a noise so great that they were terrified and ran home. Even then they heard the noise around their house.

To harm a person through witchcraft, make a figure of him in wax and wrap it in rags. Whatever is done to it occurs to the victim as well. When a person thinks himself being thus harmed, he counteracts the injury by a similar procedure. To fill the person with boils, corn is parched before the figure.

To check a sleight-of-hand performer, a person may carry a humming-bird (No. 453), a snake's rattle (No. 456), an alacran (scorpion), or other poisonous object to the show. The performer is thus rendered unable to perform his tricks

An Indian woman at Tuxpam offered to perform witchcraft for a young man. She required simply two bottles of cocoa-oil (No. 468), one with three pints of oil, the other with one pint and a half. She had the reputation of being able to change the sex of any person. 


\section{AGuiAs POPULAR DIVINATION.}

\section{Agudas Marciales: "needles of March."}

Four small sticks are cut, of any wood, but preferably of the plant called romero: these are about eight inches in length, are notched at one end, and are in pairs; one of each pair is stouter or thicker than the other. To be efficacious, one must be cut on each Friday in March. The sticks are used to find concealed metal or buried bones. Two persons take part in the operation. They sit facing each other; each takes one pair of the sticks in his hands, the longer and stouter stick being in the right, the other in the left hand. They are then placed so as to touch each other, the notched end of one long one fitting against the notched end of the short one of the other pair. They are near together, straight, and parallel. Held thus firmly but not forcibly, in a moment they begin to bend : the movement may effect both pair of sticks similarly, or one much more than the other. The direction of movement is the direction in which the metal lies. In case the pointing is toward bones, the two pairs of sticks cross so as to produce a diamond-shaped figure. The wooden sticks are often replaced by little steel rods, cleft or notched at one end. In such case the rods are made one on each Friday in March.

470. Set of Agudas Marciales, made of the wood of romero: Guadalajara.

471. Set of Agudas Marciales, made of steel: Guadalajara.

\section{Sieve Divination:}

To answer any question, to find out if one is loved, to learn if love is reciprocated, to decide a business problem, to determine regarding a removal or change of location: set a sieve 
on edge, stick into the upper edge a pair of scissors opened, place inside on lower rim a molcajote grinding-stone. Then repeat the following :-

Cedazito por la virtud que tienes

por San Pedro y San Pablo

dime si es cierto esto.

Little sieve, by the virtue you have,

by St. Peter and Saint Paul, tell me if this is so.

Thereupon the sieve moves; if the mouth turns toward the diviner, the answer is affirmative or favourable; if it turns away, the reply is negative or unfavourable.

472. Full set of the above, placed in position. Guadalajara.

To determine in what direction a missing person is. A small jicara is taken and a burning candle is placed within it. The whole is then carefully placed in a large vessel of water. A prayer is said and then the question is asked, Is at — ? and a long list of places and directions is named. The direction in which the little light drifts decides which of the places named is the present location of the missing person.

473. Jicara and candle: Guadalajara.

To find a drowned person's body. Any small vessel is taken and a sacred candle-vela santissimo (No.-) - is placed in it and lighted. This is set afloat, and stops above the spot where the body lies 


\section{POPULAR MEDICINE.}

In many markets the woman who sells remedios is the most interesting vender. Sometimes her stock numbers two hundred or more remedies. It includes materials from the animal, vegetable, and mineral kingdoms. Not only the old women in charge, but often men, women, and children, lookers-on, can tell you the names of the remedies, for what they are useful, and how they must be taken. This popular knowledge is largely a survival from the old Indian days. See Mexican Popular Medicine, by the author (No.618). Only a sufficient series is given to show range.

474. Mariguana: herb. Used for internal disorders. This plant is much smoked for intoxicating effects. Its sale is prohibited.

475. Caña fistula: Pods. Steeped and taken for lung trouble. 476. Palomita: pods of a species of passion-flower. The flat winged seeds are moistened with white wine and stuck to the temples to cure headache.

477. Flor de peña: resurrection plant. A tea is made of it, with which the face is washed to remove "blackheads."

478. Taquachi : tail of opossum. An application of this is made for drawing out spines.

479. Concha de armadillo: armadillo shell. Burned, and fumes inhaled for coughs and chills. It is also burned with chili for driving away cockroaches.

480. Cuero de vivora: snake-skin. For throbbing temples and nervous pains; pieces are cut and stuck on the temples under disks of green leaf: "four pieces are necessary, two on the face, and two on the back of the neck."

481. Colmillo de Caiman : alligator's tooth. For hearttrouble or for bite of rattlesnake. Dip into boiling water and drink this. 
482. Concha fina del mar: fine sea shell. Dipped into lemon juice mixed with the flower of romero and then rubbed upon scars to remove them.

483. Concha nacre: pearl shell. Scraped powder of this is mixed with salt and used for growths over the eye.

484. Concha de Costillon: Ribbed shell. Large limpet. Burnt and ground, the dust is taken in wine for quenching bloody flux.

485. Cangrejo: crab. Fround and boiled in water, is taken for fever.

486. Aje : An insect-coccus. These are packed in little packets of corn-husk as here seen. They are boiled with chocolate, which is drunk for headaches.

487. Borrego encino: oak galls. Ground and applied to chafed and sore spots on children.

488. Comeji : ants' nest. Steeped, it is taken for hiccoughs, neuralgic troubles, nausea and female complaints. Burned, the smoke is inhaled for the air passages.

489. Estrella de Mar: starfish. Ground and mixed with red wine, it is used for bloody flux.

490. Flor de Mar: coral or sea-fan. Burned and used for heart-suspension, etc.

491. Sesor de cantera: To avoid pregnancy.

492. Hueso de gigante: giant's bone: fossil bone. Powdered and taken as a powder at time of monthly sickness.

493. Tierra de Valladolid : Valladolid earth. Taken as a powder.

494. Photograph of a tinsmith's shop at Aguas Calientes. which is at the same time a remedio shop. This tinner-druggist combination might appear somewhat curious. 


\section{EXAMPLES OF CONSERVATISM.}

\section{FLINTS AND STEELS:}

The old-fashioned flint and steel for making fire are still much used in Mexico. The practice is most common in the country districts and among older men. It is not confined, however, to them, and even in the large cities are to be found rather neat combinations of tube, tinder-string, and flint for lighting cigarettes, and used mainly by young men. In all the little baratillas and thieves' markets old flints and rusty steels can be picked up. They represent a variety of forms.

495. Steel (2)

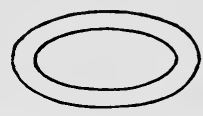

496. " (2) commonest form
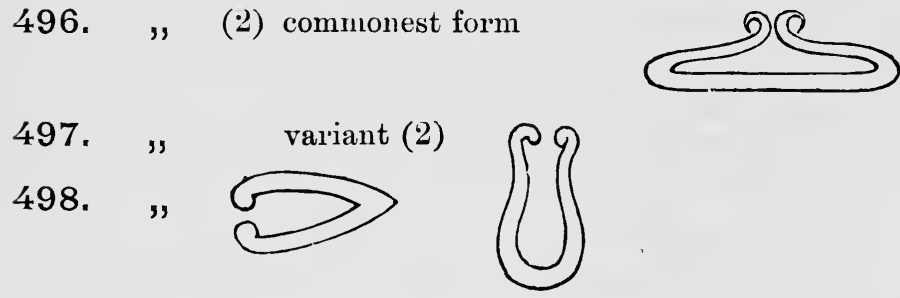

499. " $"(2)$ one with initials.

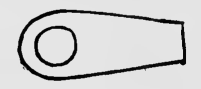

500. Flints (4).

\section{THE NIGKEL RIOTS:}

Late in the year 1883, in response to a real need, the Mexican Government began the issue of small nickel coins. These were in three denominations-one, two, and five centavos-all 
of one general pattern. Five hundred and sixty tons of metal were consumed, and 190,000,000 pieces coined.

$$
\begin{array}{r}
100,000,000 \text { of the one centavo. } \\
50,000,000 \text { of the two centavo. } \\
40,000,000 \text { of the five centavo. }
\end{array}
$$

They would have been looked upon with suspicion, as being a radical innovation, anyway; but unfortunately an erroneous method was pursued in their floating. Yet more, they were limited as legal tender, and were not unqualifiedly accepted in payment of government dues. Discrimination set in. Persons refused to receive the new coin. On December 22 a quarrel arose in the city market between a customer and a seller, who refused to receive the nickel coins. A crowd gathered: police interference was in vain: the mob moved up the important streets Plateros and San Francisco, destroying lamps and window-glass. Business-houses closed. President Gonzales drove about the city, trying to restore order; and troops were ordered out in the afternoon. Disorder and cries of "death to nickel" were everywhere seen and heard. A policeman was killed. The city council announced that the government would open stores where provisions would be sold at ordinary prices for nickel coins. The next day many shops remained closed; nickel was refused at others; but the government declared it would stand firm. Certificates exchangeable for nickel were made legal as payment for taxes. Notwithstanding these vigorous efforts to restore confidence, by December 27 the discount was seven and a half per cent., and the coins were generally refused. On the 28th, governmentagents were in the Plaza with six thousand dollars, to redeem the coins, but one dollar and a half being redeemed for any one person. A meeting of merchants tried to devise plans of relief.

The government yielded, rescinded act to arrest and 
punish storekeepers who closed their shops to avoid receiving coins, and pledged themselves to redeem the coins. On January 1, a contract was signed with private parties who arranged and carried out a plan of redemption. While a part of the failure of this coinage is to be attributed to bad management in setting it into circulation, an equally large part certainly was due to the innate suspiciousness and dislike of innovation of the people.

501. Nickel coin : one centavo.

502. Nickel coin : two centavos.

503. Nickel coin : five centavos. 
$+\cdots$
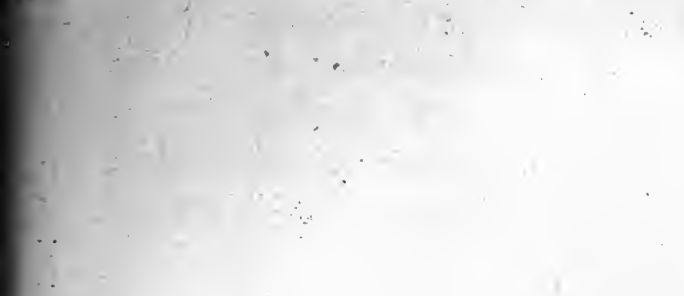

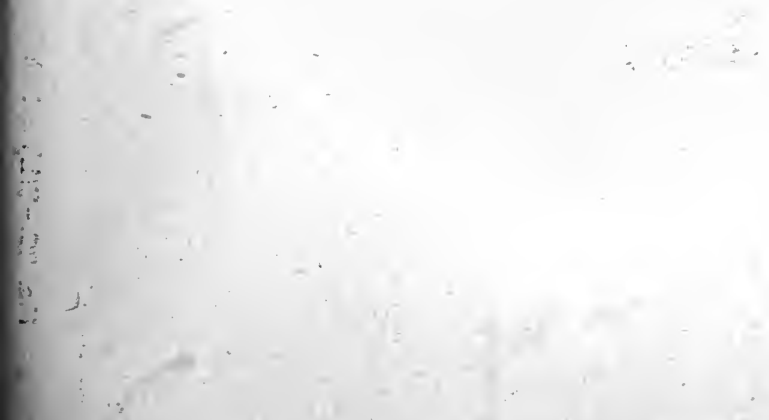

-

11 


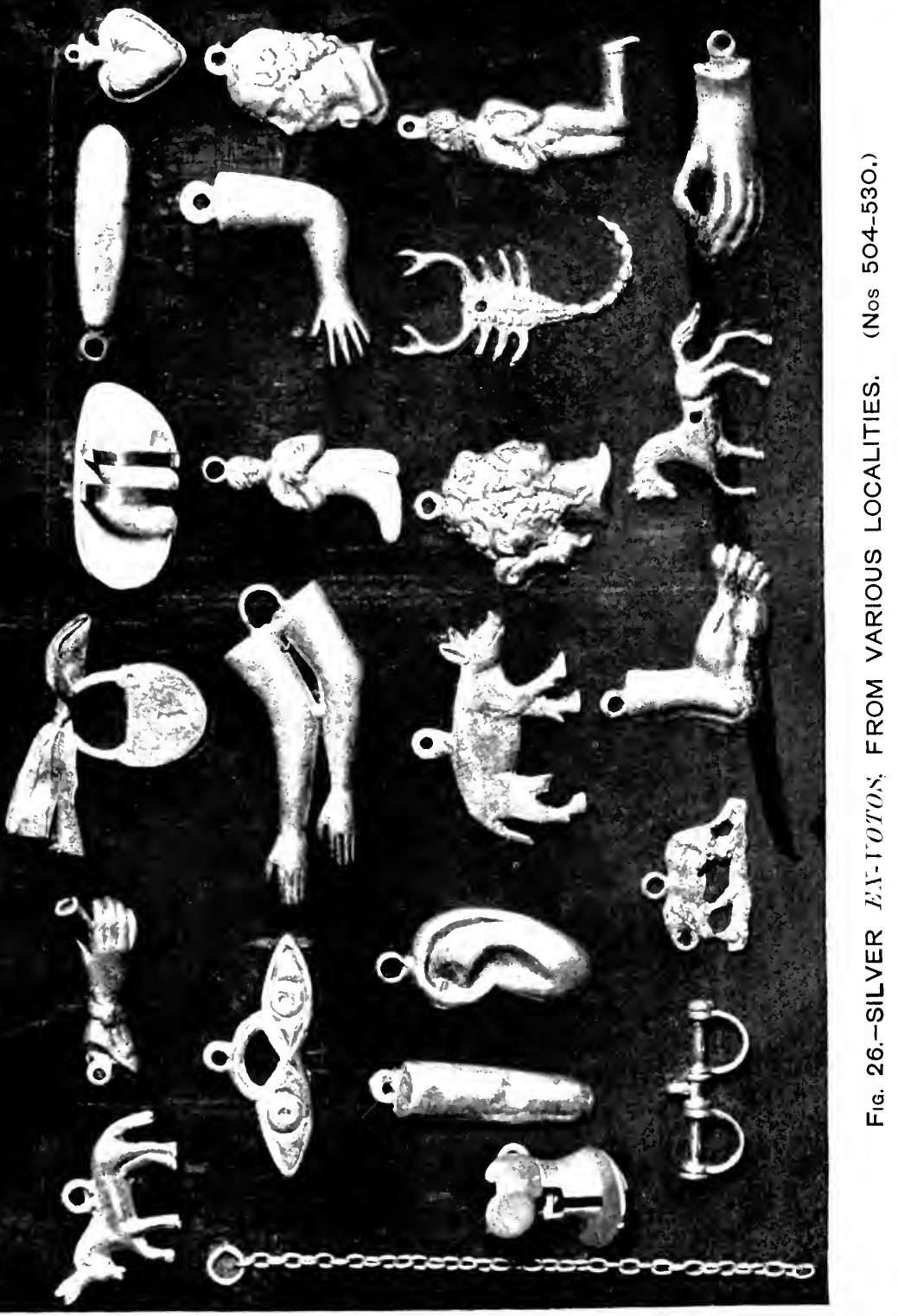




\section{VOTIVE OFFERINGS.}

\section{VOTIVE OFFERINGS IN SILVER.}

The commonest form of votive offering in the churches is made of silver. They are usually fastened with a bit of ribbon to a frame or support placed by the side of some saint. At some popular saints hundreds of these little objects, representing a considerable sum of money, may be seen. The commoner forms represent some part of the human body, and are offered in gratitude and in fulfilment of a vow for the curing of some trouble in the affected part. Thus for cure of some head trouble a head, for cure of earache or of deafness an ear, for cure of rheumatism and lameness a leg, etc., etc., may be offered.

504. Eyes.

505. Ear.

506. Tongue.

507-508. Arms.

509-510. Hands.

511. Finger.

512. Heart.

513. L.eg.

514. Foot.

515. Male head.

516. Female head.

It is customary, when a head is promised, for the indi,vidual to select one representing his or her own sex. This is also true in regard to the kneeling figures, which are given as votives for answered prayer.

517. Male figure kneeling.

518. Female figure kneeling. 
Sometimes the desire has been for the return of a lost or stolen domestic animal, or for its recovery from disease, or for its fertility in producing young, or for its successful fattening. Very common are the votives in the form of domestic animals.

519. Cow.

520. Horse.

521. Donkey.

522. Pig.

523. Fowl.

Quite of another class are the representations of harmful animals or objects. Thus, a scorpion or lizard may indicate escape from the bad results of a sting by a scorpion or the bite of an alligator: while a dagger may indicate the happy escape from the assassin's knife.

524. Lizard.

524. Scorpion.

526. Saddle.

527. Lock.

All from Puebla.

At Huixquelucan, between Mexico City and Toluca, the capital of the State of Mexico, is the so called Church of the Thieves. The town is an almost purely Otomi Indian town, and is situated on the main high-road leading west from the City of Mexico. The way was once famous for its highway robberies; and many a luckless traveller has walked into the city despoiled of his valuables, and in many cases almost denuded of clothing. The so-called Hill of the Crosses looks down upon the town, and bristles with crosses of wood, each of which is believed to mark the spot of a deed of murder. It is said that formerly the town was largely interested in robbery, and that then it was no uncommon thing to find in the church, before the saint, little silver chains and handcuffs, votives 
promised by prisoners who wished for escape or pardon from their confinement. If this were true formerly, it is no longer so ; and such votives are now rare. Silversmiths, however, are still called upon occasionally to make them. The usual reason now given for them is that they are intended for couples about to be married, and that they signify a desire for firm and honest vows. In Guadalajara a quite brisk trade is driven for Holy Week in little manacles of silver with chains attached. They are made as votives for the penitents, and represent the manacles that used to be worn by them upon their ankles in their processions.

Sometimes the vow for some favour is to supply the Nino Dios, or the Child-God, with a pair of silver sandals. These are frequently of considerable size and expense and carefully made. The pair in the collection is small and badly done. Another Cristo is often crowned with a little crown of silver in fulfilment of a vow.

528. Manacles and Chain: Guadalajara.

529. Sandals for the Nino Dios : ",

530. Silver Crown for Cristo: Guadalajara.

\section{VOTIVE OFFERINGS IN WAX:}

While these silver votives are found in use almost everywhere, they are in many places entirely replaced by those of white wax. Thus, at Leon there are many times more of these than of the silver ones. They are made in moulds. The real ones meant for use are very thin and fragile, and cost a medio, or six centavos. The specimens in the collection are from Leon, and were made solid in order to stand transportation. In the little side chapel of Our Lady of Lourdes at the Calvario, Leon, the walls are absolutely covered with votive offerings. Silver 
milagros are rare; but these wax gifts number thousands, and hang in great bunches of hundreds each. Besides these, are numbers of little hats or sombreros made of straw, and small baskets of pretty form and dainty workmanship. Little crutches and walking-sticks bear witness to cured lameness. Hundreds of plates of tin bear pictures of cures effected or deliverance given from danger, and have long inscriptions narrating the event.

531. Figure: man.

532. woman.

533. Human head.

534. Eyes.

535. Heart.

536. Leg.

537. Dog.

538. Cat.

539. Sheep.

540. Donkey.

541. Cow.

542. Rooster.

All from Leon.

\section{VOTIVE PAINTINGS UPON TIN :}

543. Bears a painting representing a woman kneeling, with a child in her arms: also a woman kneeling with a burning candle before Our Lady of Lourdes. The inscription, which is badly spelled, reads: "Milagro que Obro N. S. de Lourdes con Musia Romero que allandose afigida por la escasas de alimento para una niña sulla. Ymboco con b̉eras de Su corazon ú esta milagrosa ymagen quien le ollo piadosa y le dio su alibio y jara perpetua memoria le dedican el presente retablo Mallo 11 de 1886." Miracle which our Lady of Lourdes worked upon Musia Romero, who being afflicted with lack of food 
for her child invoked with her whole heart this miraculous image, who pityingly listened and gave her relief. As a perpetual remembrance she dedicates this tablct, May 11, 1886.

544. "Milagro que iso Nra. Sa. de Lourdes con Felipe Garcia que á biendole suse dido la desgrasia que lo hubieran. Echado á los soldados porun grimen y su afigida Ermana Braulia Ernandez ynboco con beras de sue Corazon á la Sma. Virguen y fué quien lo puso en libertad el dia 21 de Julia de 1890 presento Este Retablo." Miracle which our Lady of Lourdes worked for Felipe Garcia, who had the misfortune to be pressed into service as a soldier for a crime which he had committed. His sorrowful sister Braulia Hernandez invoked with all her heart the Holy Virgin, who gave him his liberty the 2lst of July, 1890. She presents this tablet.

The pious sister is shown kneeling in prayer before the Virgin, while her brother looks out through the prisongratings.

545. "Berdadero Retrato de N. S. de Lourdes que iso con Pablo Lopez y su Yjo Epitasio Lopez que biniendo en un Corro se callo dicho Pablo y le paso la rueda por el estomago y mirandoce en tan fuerte trance inboco á esta dibina Señora que lo faboreciear de tan fuerte trance y le mandaría un retablo en el que da gracias por tal portento, Julio 16 de 1886." True portrait of our Lady of Lcurdes, who worked a miracle upon Pablo Lopez and his son Epitasio Lopez in that, going in a cart, said Pablo fell and the wheel passed over his stomach. Finding himself in such a dire emergency he invoked that divine lady that she should favour him in his emergency, and vowed a tablet in which he should give thanks for such a miracle, July 16, 1886.

The father and son kneel in proper attitude before the Virgin. 
546. "Milagro que hizo Ma. Sa. de Lourdes con Ma. Patricia Vasquez librndola del peligro de muerte de unos ataques fuertes que le dieron. Su espos y familia dedican este retablo. Juno $14 \mathrm{del}$ Año de 1891." Miracle which most Holy Mary of Lourdes worked upon Maria Patricia Vasquez, delivering her from danger of death from terrible fits which she had. Her husband and family dedicate this tablet, June 14 in the year 1891 .

A woman dressed in red, burns a candle before the image : behind her kneel on the open plain a man, a boy, and a woman, with an infant in her arms.

547. “El ano de 1881 se vio de peligro de perder la vida Dn. Ponciano Hernandez por abersele boltiado el carreton donde venia y lo hagarro debajo y/ todas las losas calleron sobre el en este conflito se encomendo al Sr. del hospital de Sclamanca y su esposa Da. Bictoriana Ranjel ofrecio este retablo a $N$. Sra. de Lourdes por su salud y quedó sano." In the year 1881 Don Ponciano Hernandez found himself in danger of losing his life, because of the cart in which he was riding turning over upon him, catching him under it, and all the stones in it falling upon him. In this crisis he committed himself to the Sr. of the Hospital of Salamanca, and his wife, Dona Victoriana Ranjel, offered this tablet to our Lady of Lourdes for his recovery, and he was healed.

The right half of the plaque is occupied by the Virgin's picture, while to the left kneel the wife, with an exceedingly small infant in her arms, and the man upon whom the miracle was worked.

548. "Milagro que ios Nuestra Senora de Lurdes con Petra Gomez que ailandose en copania de su ermano y su familia 18 de Juniot de 1888." Miracle which our Lady of Lourdes did with Petra Gomez, who found herself in company with her brother and his family on the 18th of June, 1888. 
The inscription is unsatisfactory, but the picture and the date tell the story. The city of Leon has not yet recovered from the disastrous effects of the terrible inundation of 1888 . The painting represents our Lady of Lourdes to the right, the remainder of the plate is occupied by a sea of waters, upon whose billows floats a small raft, upon which sit a man and two women, each of the latter of whom carries a baby in her arms.

Such votives as the preceding six, which were taken from the chapel of our Lady of Lourdes at Leon, are to be found in all parts of the country where the mixture of Spanish and Indian blood occurs. They usually have to the right a picture of the saint, to which they are offered, with the person who makes the offering kneeling in prayer before it: the rest of the plate is occupied by a picture of the danger from which rescue was asked. The picture of the suppliant, therefore, usually appears twice in each case.

\section{MISCELLANEOUS VOTIVES.}

549. Small hat of straw: taken from the shrine of our Lady of Lourdes at Leon. Was given by a hatmaker to gain success in his trade. 


\section{RELIGIOUS MISCELLANY.}

\section{FLAGELLATION :}

Until quite recently self-torture has been common in Mexico. Notably indulged in by nuns and monks in the convents and monasteries, it was also practised by the common people. Bands of netted iron points called cilicias were worn about the forehead and waist, and pairs of similar bands were tightly bound around the arms, wrists, or legs, so as to drive the projecting points into the flesh. Hearts and crosses with projecting points were bound on the chest over the heart: soles with upturned spikes were fastened to the feet of penitents who had vowed to walk a certain distance in this unpleasant foot-gear: caps lined with points were bound upon the bare knees, and the penitent crawled for a certain time upon his knees, while each movement drove the points deeper into his flesh. Iron scourges with points which tore the flesh were used, blows upon the bare back being given by throwing the instrument over the two shoulders alternately: each blow brought blood. These scourges are called disciplinas.

Madam Calderon de la Barca describes the use of these disciplinas, or scourges, in her Life in Mexico, p. 213-214. She says:

"The scene was curious. About one hundred and fifty men, enveloped in cloaks and serapes, their faces entirely concealed, were assembled in the body of the church. A monk had just mounted the pulpit, and the church was dimly lighted, except where he stood in bold relief, with his grey robes and cowl thrown back, giving a full view of his higb, bold forehead and expressive face. His discourse was a rude and very forcible and eloquent descrip- 
tion of the torments prepared in hell for impenitent sinners. The effect of the whole was very solemn. It appeared like the preparation for the execution of a multitude of condemned criminals. When the discourse was finished they all joined in prayer with much fervor and enthusiasm, beating their breasts and falling upon their faces. Then the monk stood up and in a very distinct voice read several passages of Scripture descriptive of the sufferings of Christ. The organ then struck up the Miserere, and all of a sudden the church was plunged in profound darkness-all but a sculptured representation of the Crucifixion, which seemed to hang in the air illuminated. I felt rather frightened, and would have been very glad to leave the church, but it would have been impossible in the darkness. Suddenly a terrible voice in the dark cried, 'My brothers, when Christ was fastened to the pillar by the Jews hewas scourged.' At these words the bright figure disappeared and the darkness became total. Suddenly we heard the sound of hundreds of scourges descending upon the bare flesh. I cannot conceive anything more horrible. Before ten minutes had passed the sound became splashing from the blood that was flowing. We could not leave the church, but it was perfectly sickening; and had I not been able to take hold of the senora's hand and feel something human beside me I could have fancied myself transported into a congregation of evil spirits. Now and then, but very seldom, a suppressed groan was heard, and occasionally the voice of the monk encouraging them by ejaculations or by short passages from Scripture. Sometimes the organ struck up, and the poor wretches, in a faint voice, tried to join in the Miserere. The sound of the scourging is indescribable. At the end of half an hour a little bell was rung, and the voice of the monk was heard calling upon them to desist : but such was their enthusiasm that the horrible lashing continued louder and fiercer than ever. In vain he entreated them not to kill themselves, and assured them that Heaven would be satisfied, and that human nature could not endure beyond a certain point. No answer, but the loud sound of the scourges, which are many of them of iron, with sharp 
points that enter the flesh. At length, as if they were perfectly exhausted, the sound grew fainter, and little by little ceased altogether."

Such self-torture is now forbidden by law, but no doubt some of it still takes place. Old cilicias and disciplinas can occasionally be bought in the cheap markets. Rev. D. A. Wilson of Guadalajara has a good collection of these instruments, showing all the types above mentioned.

550. Cilicias : pair on cloth back.

551. Cilicias: iron network bands.

552. Cilicia : for waist.

553. Pair of Soles with points.

554. Cross to be worn over the heart.

555. Cross

556. Pair of Knee Caps with points.

557. Disciplina : of iron.

558. Photograph of Wilson Collection.

A milder form of such torture has arisen or at least grown in popularity lately. In many cities-as Guadalajara, Aguas Calientes, Toluca-are Casas de Ejercios, Houses of Exercise, where persons may devote themselves to meditation, prayer, fasting, and flagellation for any specified time. The time of all others, however, is Holy Week. Then these places are filled with devotees who enter for a nine days' retreat from the world. In 1895 the number at the Casa de Ejercios at Guadalajara was about fifteen hundred. The house there is very completely equipped. There are beautiful patios, the corridors around which are decorated with pictures and mottoes calculated to assist in directing the thoughts of the penitents; a great refectory, plain and simple, where the worshippers eat the permitted stint; cells for one or several, where they sleep at night, or to which they withdraw for meditation during the 


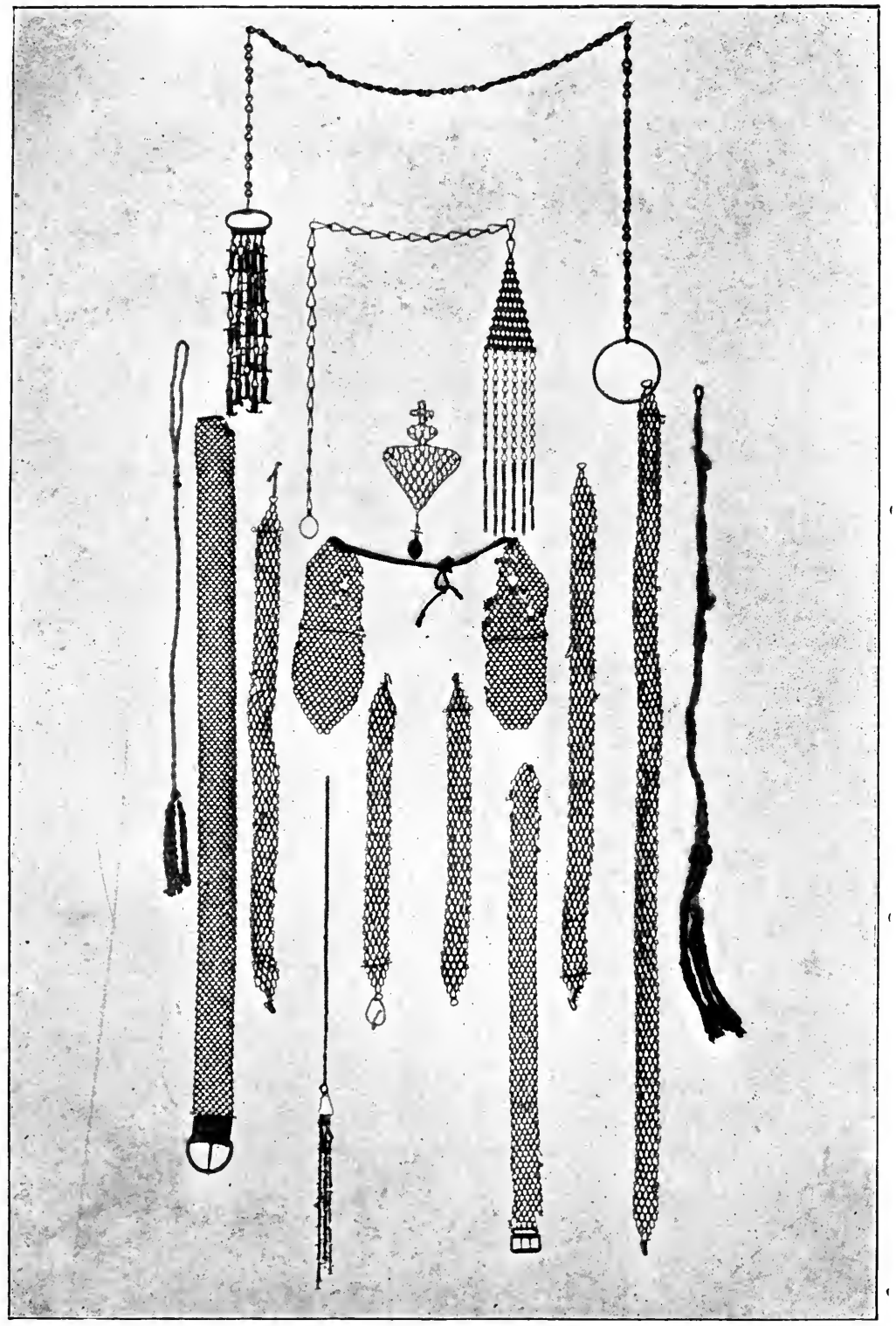

FIG. 27.-COLLECTION OF CILICIAS AND DISCIPLINAS, BELONGING TO Mr. D. A. WILSON, GUADALAJARA. (No. 558.) 

day; chapels where they listen to earnest but emotional sermons. These stir the heart, and audiences of hundreds are swayed to tears and heartrending groans of anguish. I have seen an audience of nine hundred women with crowns of thorns laid upon their heads, weeping like children at the story of the Lord's passion. At one time-Good Friday-crowns of thorns are worn upon the bared forehead, and self-beating is done with disciplinas made of twisted cords or leathern thongs.

559. Disciplina of Cords : Casa de Ejercios, Guadalajaro. 560. Crown of Thorns 561. Crown of Thorns

\section{MEDALS :}

As elsewhere stated, charms and amulets apart from those which are blessed by the Church seem to be little used in Mexico. These, however, are numerous and varied. (See Medals, Medidas, and Scapularios.) Almost all the common people wear or carry one or more of these upon their persons. Of medals many were formerly made representing local saints. To-day almost all are made abroad-especially in France-and represent foreign saints and bear inscriptions in foreign languages. Recent medals of our Lady of Guadalupe are imported. The medals included in the collection all relate to local saints.

562. Medal: Virgen de Guadalupe. (See 595.)

563.

564. ,

565.

566. ,

567. ,

568. ,

569. ,
Senor de Santa Teresa. (See 597.)

Virgen de los Remedios. (See 596.) 
570. Medal : Virgen de Ocotlan. (See 600)

571. " Virgen de Zapopan.

This image is much venerated. Zapopan is a suburb of the beautiful city of Guadalajara, a city with 37 or 38 churches. The district is subject to terrific thunderstorms, and "Our Lady of Zapopan " is brought into the city at the time of the beginning of the rainy season as a protection against lightning. During her sojourn, which lasts until the close of the season of rains, she makes the round of the churches, a printed list being prepared giving her dates at each. While she is present in any church it is thronged with visitors. Before the Laws of the Reform put an end to religious processions, her comings and goings were occasions of great outdoor gatherings and rejoicings.

\section{MEDIDAS :}

At many shrines and churches where miraculous saints or miracle-working saints are located, there are sold strips of ribbon upon which are marked the measure of some part of the image. The measure (medida) is usually that of the head circumference. The ribbon bears printed upon it the statement that it is the exact measure of the part in question.

572. Medida: Guadalupe. (See 595.)

573. Medida: Virgen de los Remedios. Cholula.

This church is interesting because of its replacing a pagan temple upon the summit of the great and famous pyramid of Cholula. The figure of the Virgin of the Remedies there is commonly believed to be one which miraculously appeared in the air and led the Christians on to victory. (See Mapa de Cuauhtlantzinco 617.) It is probable, however, that this image is in Puebla and not in Cholula. 


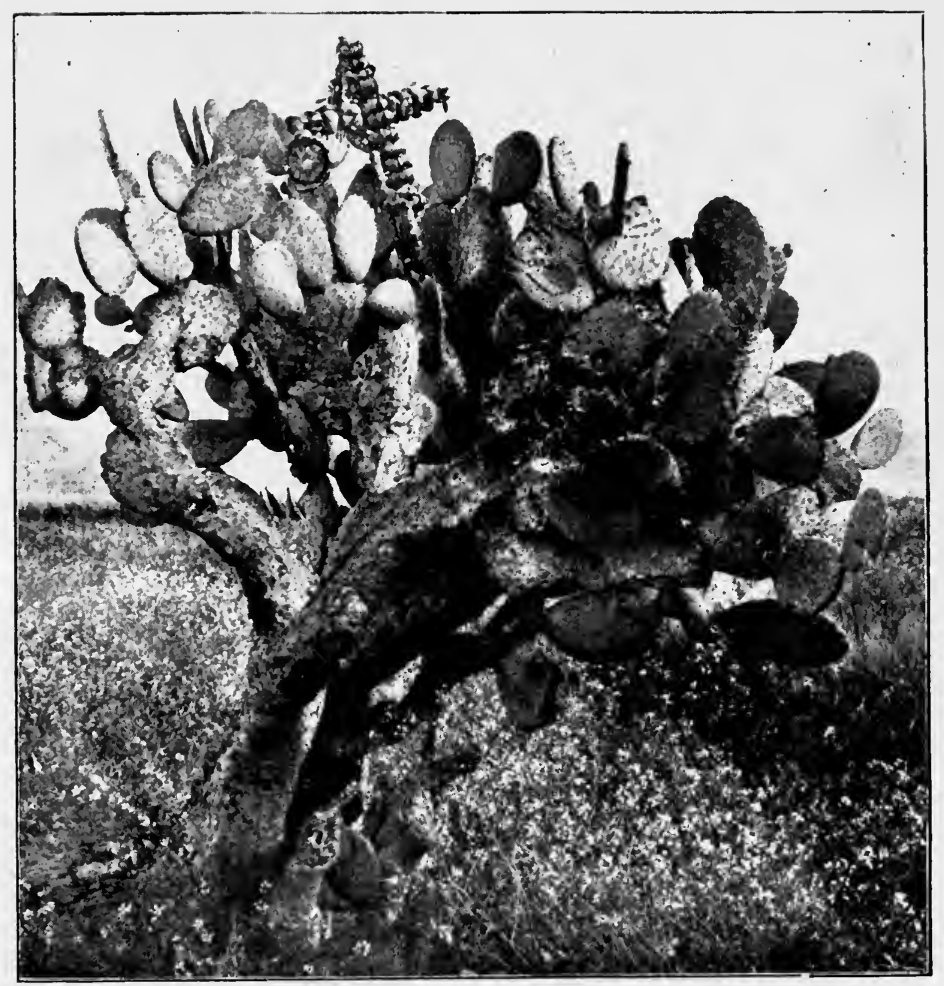

FIG. 28.-CROSS TO ENSURE SUCCESS OF CROPS: NEAR TEZONTEPEC. (No. 578.) 



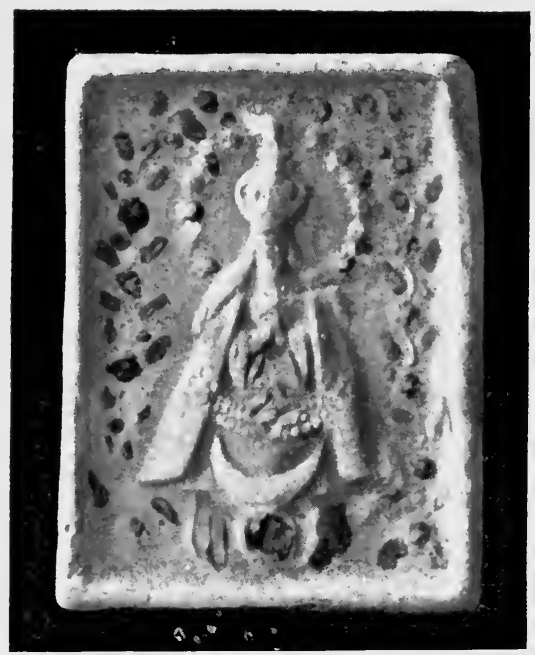

FIG. 29.-CAKE OF EARTH: LAGOS. (No 579.)

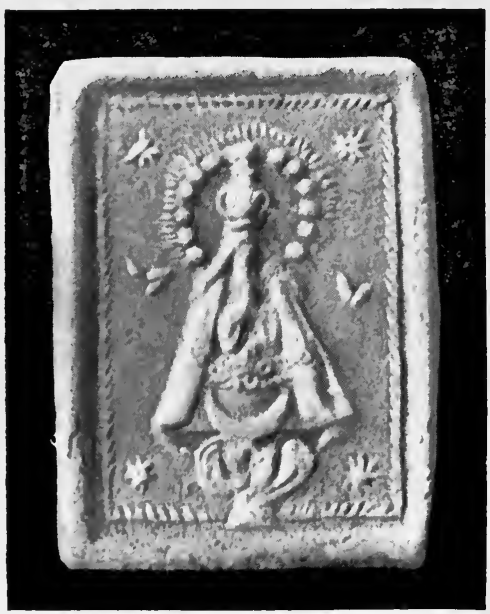

FIG. 30.-CAKE OF EARTH : LAGOS. (No. 580) 
574. Medida: Virgen de la Soledad. Puebla.

575. $" \quad$ Puebla.

576. " Señor de Ixtapalapa.

The famous Christ here is in a church close by an anciently sacred spring (see 605) and at the foot of the famous Hill of the Star, on whose summit the new fire of the secular feast was kindled-one of the sacred spots of ancient and of modern Mexico.

577. Cross made of flowers: On the 3rd of May these are set up near fields of corn or other crops to insure success for the year. Tezontepec: State of Hidalgo.

578. Photograph: same in position.

At a number of places a white earth, believed to have healing qualities, is pressed into small rectangular cakes stamped with a figure of the Virgin of the place. These are sold everywhere, but chiefly at the shrine of the Virgin represented. A bit of the cake broken off and mixed with water cures disease.

579. Cake of pressed earth : from the Church of San Juan de Lagos.

This place is famous for a great annual fair. The Virgin of the church is a favourite, pilgrimages being made from great distances. As an example of the way in which people congregate there from every part, I knew two men who planned to go to the Lagos fair in 1898, hoping to find there a brother, who had been lost sight of for some time, and of whose whereabouts and welfare they were anxious to learn.

580. The same.

581. Earth-cake : figure of the Virgin of Talpa.

This is a famous figure in the town of Talpa, on the Pacific slope of Jalisco. The Virgins of Zapopan, Lagos, and Talpa 
are commonly considered as sisters, and are called "the three sister Virgins."

582. Earth-cake: figure of Virgin of Guadalupe. (See 595.) 583. Earth cake: same but smaller and of different form.

On Palm Sunday, palms are brought from the tierra caliente to all the great cities of Mexico. In the market-place the sellers sit and plait these into simple or complex designs, some of which are very pretty. These they sell; and after they have been blessed in the church they are placed upon the house of the purchaser, usually attached to the balcony-railing, or to the iron bars outside windows. There they protect the house, especially against lightning and storm, but also against evil spirits and other ill fortune.

584. Braided palm : Guadalajara.

585.

586.

587.

588.

589.

\section{SCAPULARS :}

The Scapulars in the collection are simply illustrative. They either have special use or are from interesting localities.

590. Scapular: Guadalupe. (See 595.)

591. Scapular: Señor de Ixtapalapa. (See 576.)

592. Scapular: Cholula. (See 573.)

593. Scapular: St. Vincent Ferrer.

These are much used to give women easy childbirth. 594. Scapular: Church of Carmen, Toluca.

The Carmen scapular is much prized, but can be worn only by those accepting its somewhat austere obligations. To all such it protects from the pains of purgatory. The flames can 


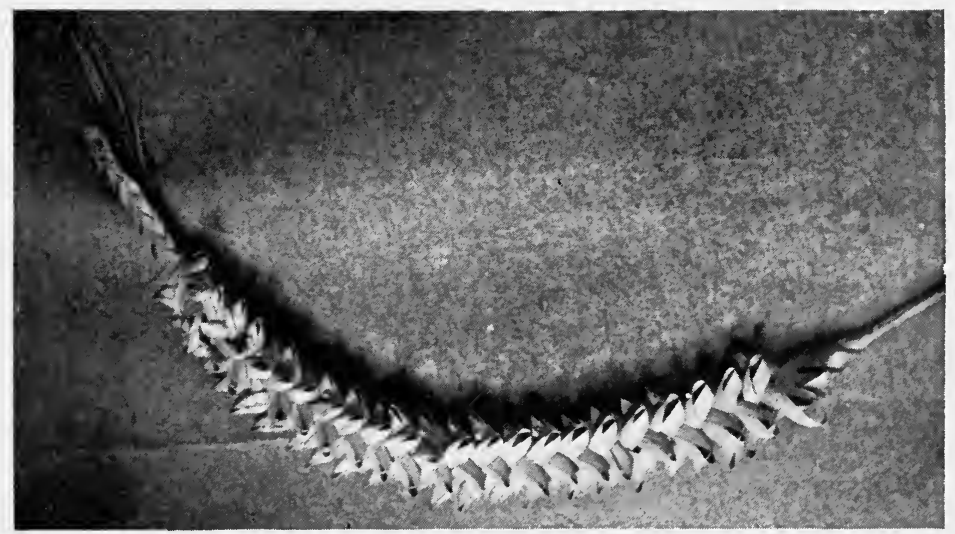

FIG. 31.-PALM BLESSED ON PALM SUNDAY: GUADALAJARA. (No. 584.) 

only reach to the point on the body to which it hangs. Hence if worn so low as to the feet it almost gives immunity. Who fitly wears it is released from purgatory on the Saturday after his death. The scapular is believed to quench destructive earthly fires, and a wealthy gentleman of good social position sent for one in haste on his home being in flames.

\section{RELIGIOUS PICTURES :}

Religious pictures are highly in vogue in Mexico. They are generally printed in black, and the same design is made in a variety of sizes. The smaller ones may be inserted in tin frames under glass and worn as scapulars. The larger ones are hung on the walls of the house. They are considerably respected, and often have candles burning or flowers placed before them. To certain, helpful powers are attributed, and it is believed that they can cure disease or ward off trouble. Especially common from this point of view is the "Shadow of St. Peter." Many of these pictures represent foreign saints, such as Our Lady of Lourdes and the holy child -niño dios, child god-of Atocha. Only those illustrating locally famous Mexican "santitos" are included in the series Nos. 595 to 603 .

595. Print: The Patron Saint of Mexico is Our Lady of Guadalupe.

This picture, in every style of workmanship and grade of excellence, is to be found from one end of the Republic to the other. It is seen in shops of every kind, even to butchers' stalls and pulque-shops, looking down benignly on the traders. Statues of this Virgin occur in many churches, and many of them are of great beauty. The original miraculous picture is a coloured design upon a blanket of $i x t l i$-fibre in the magnificent collegiate church at Guadalupe on the borders of the City of 
Mexico. This is the favourite shrine of the nation, and is specifically venerated by Indians. On and about December 13th, there are most interesting dances of Indians, and of bands dressed as Indians, in and about the church.

This hill, centuries ago, was the seat of a shrine to the "Mother of the Gods" of the Aztecs-Tonantzin : to-day it is sacred to the Virgin Mary-not to any Virgin Mary, but to her of Guadalupe, the patron saint of Mexico. Vetancurt more than two hundred years ago told how the place became sacred to the Christian. The story has been often repeated better than we can tell it.

"Juan Diego, the Indian, on his way to mass, December 9, 1531, heard a choir of angels here, and to him appeared the Virgin, commanding that a temple should be erected to her on this spot. The Indian carried the message to Bishop Zumarraga, who, incredulous, demanded a sign. Thrice more, once daily, the Virgin appeared to the poor Indian, and at last worked the required miracle. From the barren, rocky hillside grew beautiful flowers, and the command was given that these should be gathered and carried to the doubting prelate. Filling his blanket (tilma) with the miraculous flowers the happy Indian hurried to the bishop; throwing open the tilma to display the flowers, there upon it was a picture brightly painted by no human hand and representing Our Lady herself. So runs the story, and thus the sacred mountain of the Aztec pagans became the sacred mountain of the Mexican Christians." (For fuller details see Janvier's Mexican Guide, pp. 290-292.)

596. Print: The Virgen de los Remedios-Virgin of the Remedies.

She is the patron saint of the Mexican-Spanish. During the revolution she was carried to battle against the forces who bore the Virgin of Guadalupe. The story of this image is told by Janvier: 
“. . . brought to Mexico (by Juan Rodriguez de Villafuerte, one of the soldiers of Cortés). During the first and peaceful occupation of the city of Tenochtitlan, now Mexico, it was permitted to be set up in a shrine upon the great Teocalli among the Aztec gods. It was carried thence on the night of the retreat from the city, the Noche Triste, by Villafuerte: when he and all that was left of the army of Cortés sought shelter in the temple of Otoncapulco, that stood upon the hill of Totoltepec, where now is the Holy Virgin's shrine. And by the temple, being too sorely wounded to carry it further, he hid the image beneath a maguey and left it there. In the year 1540 a certain Indian chief, a Christian, Don Juan de Aguila Tobar-who is also known by his heathen name of Cequauhtzin-while hunting upon this same hill, beheld a vision of the Holy Virgin, who told him to search beneath a maguey for her image. And this happened not once but several times, and then the Indian found the image and took it to his house. But the image returned again to this hill. Then did he bring it again to his bouse, and in a dish made of a gourd set before it to eat tempting things. But the image resisted the food and returned to this hill. Then did he enclose the image in a great box, fastened with strong locks ; and to make the matter still more sure he slept upon the box's lid. But in the morning the image was gone, and he found it once more upon the hill of Totoltepec, beneath the maguey. Then he told to the Fathers of San Gabriel, in Tacuba, in which town he lived, of these strange things which had befallen him; and these perceived that a miracle had been performed and a sign given showing that on the hill of her choice the Virgin should have a temple built to her honor." (Op. cit. pp. 448, 449.)

597. Print: the Christ of the Ghurch of Santa Teresa la Antigua, in the City of Mexico.

This miraculous "crucifix was brought from Spain in the year 1545 and placed in the church of the mining town of the 
Cardonal (in the present State of Hidalgo), where it was known as the Santo Cristo de Cardonal. In course of time the crucifix became injured and unsightly and was thrown into the fire to be burned. The flames failing to consume it, it was buried. Later it chanced to be dug up again and was found still uninjured. Finally it miraculously renewed its freshness and appeared as though newly made." (Janvier, p. 233.) It was subsequently removed to Mexico.

598. Print: La Senora del Pueblito de Querétaro. This pueblito lies west of the true city of Querétaro. The image represents the Senora of the Conception. It was made " in 1632 by Fray Sebastian Gallegos, a sculptor monk in the Convent of San Francisco in Querétaro, especially for the purpose of being brought to this place, and so turning from their persistent idolatry the Indians living hereabout. The image has wept many times, has sweated, has assumed on occasion a most fierce expression of countenance, and has wrought many notable miracles." (Janvier, p. 429.)

599. Print: El Senor del Santo Intierro at Amecameca. The Christ of the Holy Sepulchre.

One legendary account of the matter states that "certain muleteers who were carrying holy images to a southern town lost from their train hereabouts the mule upon which this image was packed. And when the mule was found he was standing quietly in the cave upon the mount. Thus it was seen of all the townspeople that the image was pleased to abide here with them for their protection: therefore they bought it of the muleteers and placed it in a shrine in the cave that it had chosen to be its horne ... it is certain that the image has been in this place for more than three centuries-since before the year 1550. It is made of a 
very light material, probably the pith of cornstalks prepared with some sort of gum, and although it is of life size it weighs but a little more than 5 wo pounds. A great pilgrimage is made to this shrine every Holy Week." (Janvier, p. 481.)

600. Print: La Virgen de Ocotlan. The Virgin of Ocotlan.

This is preserved in the beautiful church known as the Sanctuario, a mile from the city of Tlaxcala.

"In the first year succeeding the conquest, a certain godly Indian, whose name was Juan Diego, was most faithful in ministering to his fellow-townsmen smitten by a great pestilence that then raged in these parts. Thinkıng to procure better water for the sick to drink, he passed from the Church of San Francisco, where he had been at prayers, toward the river. And when he had come to the place where the holy well now is, where then was a grove of great pine trees, called by the Indians ocotes, he heard calling him a sweet voice, which said 'God save thee, my son. Where goest thou?' And to her he said, 'I go to bring water to them who are sick.' And she answered, 'I will give you water that will not only quench the thirst of them who are sick, but that will cure their infirmity.' And lo! from bereath a great ocote there gushed forth a sweet and lively spring! Then did the Blessed Virgin bid Juan Diego search in that spot and he would find her holy image. And having thus spoken, she vanished from him leaving him animated by a holy and tranquil joy. And when with the religious from San Franciseo he made search he found the image." (Janvier, p. 402.)

601. Print: Señor de Chalma. A figure much venerated by Indians in the Toluca Valley and adjoining districts.

602. Print: La Sen̈ora de los Remedios de Citacuaro. Our Lady of the Remedies of Citacuaro, a town in the Mazahua-Tarascan district of Michoacan. 
603. Print: El Sen̄or de Mazatepec. Our Lord of Mazatepec.

604. Print: El Nin̄o Cautivo, Mexico. The captire child Christ is found in a considerable number of churches. When mothers desire the release of a child from sickness or peril, they may tie the Niño Santo until their desire for their own is granted.

The sacred cave at Ixtapalapa has already been referred to. It contains a spring of healing water at its bottom. It is no doubt a sacred place of the old pagans, simply taken in and sanctified by the new religion. It is a hole in the lava rock, open at both ends, and descending a short distance to the cool, clear water. The cracks in the rock are stuck full of simple, almost pathetic, ex-votos, consisting of little crosses of two splints tied together or of simple wreaths of leaves or flowers.

605. Cross of splints: ex-voto. From Ixtapalapa.

At hundreds of somewhat out-of-the-way places one finds piled up before wayside shrines heaps of little pebbles. Each pious passer adds one to the cairn. Sometimes the pile is so large as to almost fill the niche or cover the cross. The Catholic priests assure me that this is not Christian, and some of them even oppose the practice. It probably is a survival from the long past. Even the persons now doing it have no clear idea of the reason why.

606. Photograph: Wayside shrine with pebble heap. Within sight of the famous hill of Guadalupe.

The favourite offering to a santo is a candle. These are usually simple and plain affairs, varying only in size and material. On February 2nd, the blessing of candles is ceremonially performed in the churches. The ceremony is one of beauty and impressiveness as conducted in the cathedrals and 


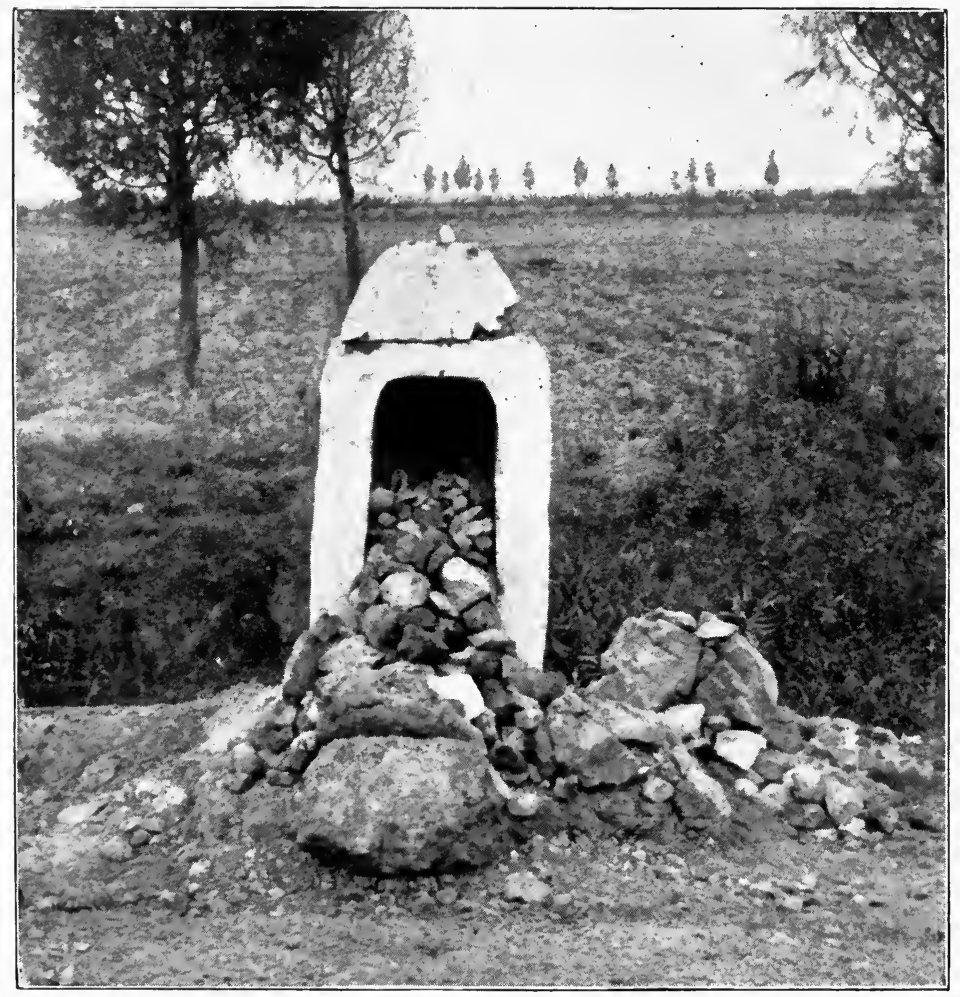

FIG. 32.- PEBBLE-SHRINE, NEAR GUADALUPE. (No.606.) 

larger churches. These blessed candles are lighted for a part of the ceremony, but are extinguished and then carefully kept to be burned at the time of death of the bearer. A long chapter of interest might be written regarding the folklore of candles in Mexico, but I am not sure how far this would be simply universally Catholic. On some occasions special candles are used.

607-608. Candles of fine white wax, with pretty embossed and raised designs. Carried by children on certain occasions.

609. Candle of the Passion: These are made of many sizes', some veritably immense. They are painted with a red ground, upon which are painted the emblems of the Passion-cross, nails, hammer, etc. They are burned in houses on Good Friday.

On February 3rd, San Blas Day, the throats are blessed in Catholic churches throughout Christendom. In Mexico, cords are blessed at the same time. These are afterward worn to protect against all throat-troubles. Many other cords are used for other purposes.

610. Cord of San Blas, amulet against throat-troubles. Guadalajara.

611. Cord of San Francisco: A copy of that worn by the Saint himself. Worn especially on his day.

Old palms, worn-out images, rosaries, sacred cords, prints etc., are burned. The priest takes these ashes, and on Ash Wednesday at early mass marks the people with the ashes. This may be done by simply dipping his finger into the ashes and daubing a spot on the forehead of the person kneeling before him. Many priests, however, cut a cross-in relief or depressed-upon the end of a cork, and with this stamp a cross on the forehead. The design must not be 
washed off, but left as long as it will last. It is called a "jesusito "-a "little Jesus."

612-613. Corks for stamping "Jesusitos" on the forehead. These were made by boys in play, but are the same as those used by the priests.

\section{PAMPHLETS AND PAPERS}

More or less directly referring to Mexican Folklore.

614. Carta Circular relating to Popular Celebrations in Mexico.

615. Popular Celebrations in Mexico.

616. The Little Pottery Objects of Lake Chapala, Mexico.

617. Mapa de Cuauhtlantzinco or Codice Campos.

618. Mexican Popular Medicine.

619. The Tastoanes.

The above papers are all by Frederick Starr.

620. Mexican Lustred Pottery: Y. H. Addis, Harper's New Monthly Magazine, August, 1889.

\section{gaw. Thacbeam}


the 
Starr, Frederick

115

Catalogue of a collection

S7 of objects illustrating the folklore of Mexico

PLEASE DO NOT REMOVE CARDS OR SLIPS FROM THIS POCKET UNIVERSITY OF TORONTO LIBRARY 
